\title{
REVISION OF ASIATIC PORANEAE (CONVOLVULACEAE) - CORDISEPALUM, DINETUS, DUPERREYA, PORANA, PORANOPSIS, AND TRIDYNAMIA
}

\author{
G.W. STAPLES \\ Bishop Museum, 1525 Bernice St., Honolulu, Hawai’i, 96817-2704, USA
}

SUMMARY

The genera Porana Burm.f. and Cordisepalum Verdc. are taxonomically revised. Five distinct groups of species segregated from Porana are here recognized at generic rank and the names Dinetus Sweet, Duperreya Gaudich., Poranopsis Roberty, and Tridynamia Gagnep., are taken up for four of them. Porana Burm.f., s.str., is herein restricted to two species. Cordisepalum is maintained as a genus distinct from, and closely related to, Poranopsis. All names are typified, selected taxa and characters are illustrated, and distribution maps are provided for all taxa. In total 20 species, one comprising two subspecies, are recognized. Two new species, Cordisepalum phalanthopetalum and Dinetus rhombicarpus, are described and illustrated. Names for Porana described from Africa, Madagascar, and the Americas are dealt with in the Species Exclusae. An index of numbered collections examined is provided.

Key words: Convolvulaceae, Cordisepalum, Duperreya, Dinetus, Porana, Poranopsis, Tridynamia, new species.

\section{INTRODUCTION}

Fifty epithets have been published or combined in Porana Burm.f. at species rank and an additional eight infraspecific taxa have been named. The majority of these taxa were described from tropical continental Asia, a few from Malesia and Australia, with widely disjunct species reported from Africa, Socotra, Madagascar, and Mexico. As historically conceived, Porana species share in common the characteristics of an enlarged, persistent, wing-like calyx that invests an indehiscent, usually one-seeded fruit with a papery pericarp. Often the fruiting sepals are two to many times longer than wide, but there are several exceptions to this generalization. Beyond these shared features, Porana species encompass a smorgasbord of morphology and ecological preferences.

The widely disjunct taxa of Porana (e.g., outside the greater Asian region) have been transferred to other genera (see Species Exclusae for list). The remaining taxa of Porana are mostly found in tropical Asia and Malesia, with two in Australia.

The present revision recognizes only 20 species, one of which includes two subspecies. A preliminary systematic analysis of these 21 taxa (Staples, 1987a) based on morphological characters indicated that they fall into five groups of species. One of these groups corresponds to a much-narrowed concept of Porana s.s. The other four species-groups are herein recognized at generic rank under the previously published generic names Dinetus Sweet, Duperreya Gaudich., Poranopsis Roberty, and 
Tridynamia Gagnep. Many of the new combinations were published already (Staples, 1993). Furthermore, the genus Cordisepalum Verdc., described as a distinct genus closely related to Porana, is maintained at generic rank and included in this revisionary study.

The preliminary systematic analysis (Staples, 1987a) indicated that these six Asian genera do not comprise a monophyletic group. Recent molecular studies support this conclusion (Stefanovic et al., 2002). The morphological analysis (Staples, 1987a) revealed that Porana s.s. has several characters that set it apart from the other species that had been included in the genus. The molecular analysis corroborates this finding and places Porana s.s. in a different tribe from the other five genera (Stefanovic et al., 2003). In the most recent infrafamilial classification of the Convolvulaceae (Stefanovic et al., 2003) the tribe Poraneae has been dissolved: Porana s.s. is included in the tribe Dichondreae, while the other five genera as recognized here are classified in the newly erected tribe Cardiochlamyeae. For present purposes, the higher level classification issues are set aside and all species formerly included in Porana s.l. are revised so that a comprehensive morphological foundation is available.

The present paper is a straightforward taxonomic revision that clarifies $\alpha$-taxonomic concepts, rectifies the nomenclature, describes and illustrates the 21 taxa recognized, and documents the geographic distribution, ecological preferences, and ethnobotanical uses for each taxon. The revision is based primarily on morphological study of herbarium specimens, over 3,700 sheets of which were examined in the course of the revision. Living material of six species was studied in the field or in cultivation. These methods were augmented by comprehensive studies of pollen characters and trichome morphology - two areas of inquiry that have proven taxonomically informative for other Convolvulaceae - using scanning electron microscopy (SEM).

\section{TAXONOMIC HISTORY}

The generic concept for Porana has undergone a gradual expansion through accretion since its inception in 1768 by N.L. Burman. Based on a single species, the original generic protologue described vegetative and floral morphology but omitted fruits. Later authors described additional species of Porana with increasing emphasis on the fruiting calyx. Over time the generic concept became increasingly heterogeneous, especially in regard to floral morphology. Ultimately, the generic concept for Porana became quite amorphous except for the shared common features of accrescent calyces with fruiting sepals longer than broad and a papery-walled fruit.

The taxonomic history that follows is presented in chronological order except where two or more treatments by the same author appeared in a brief span of time; these have been grouped together for convenience. Only selected treatments - those which added information pertinent to the development of the generic concept - have been included.

Burman (1768) named the genus Porana, based on P. volubilis, from flowering material collected by Kleinhoff [or Kleynhof] on Java. The 'Flora indica' plate, numbered $21^{* 1}$, examined in conjunction with the protologue, is sufficient to identify

1) Some copies of 'Flora indica' lack plate 21*, as noted by Robert Wight (vide infra). 
$P$. volubilis as a member of the Convolvulaceae, but little more. Omitted is any mention of the fruits, the fruiting calyx, the number of locules in the ovary, and the number of ovules, all points that later proved important in characterizing Porana.

Linnaeus (1771) paraphrased Burman's description and first commented on the fruiting sepals of $P$. volubilis, "Cal[yx] ... in fructu grandioribus." He also described the fruit, "Per[icarp] ... bivalve." Linnaeus marked the genus with the dagger $(\dagger)$, which can mean uncertainty about the affinity of the plant, and he placed it in the appendix to the Mantissa altera, and not with the other genera of the Convolvulaceae, which mostly occur in the Pentandria - Monogynia of the Linnaean Sexual System.

Two phrases in the Linnaean description (Linnaeus 1771: 560) for $P$. volubilis are curious, "Folia serrata" and "Flores ... an nonnulli masculi apetali?" neither of which correspond to $P$. volubilis as currently understood. Linnaeus evidently examined a specimen since he was able to expand on Burman's description in this way, but none are cited. No material of Porana is extant in the Linnaean herbarium (Savage, 1945). However, there is one sheet, numbered 305.1, in the J.E. Smith Herbarium (LINNSmith), which is annotated in the handwriting of Linnaeus f. with the name Porana volubilis and "Thunb." According to Savage (1963) such sheets annotated by Linnaeus f. were formerly in the Linnaean Herbarium and came into Smith's possession either as a gift from the younger Linnaeus when he visited London, 1781-1782, or when Smith bought the Linnean Collections after the death of Linnaeus f. in 1783. It is quite possible that this specimen of $P$. volubilis was examined by the senior Linnaeus and was the basis for his peculiar comments (1771: 560): the leaves of sheet 305.1 dried with slightly undulate margins that appear vaguely serrate, and the flowers consist of calyces with pistils but the corollas have all dropped off, taking the stamens with them.

Jussieu (1789) paraphrased Burman's description and Linnaeus' comments, omitting the reference to serrate leaves but including the cryptic remark about the apetalous flowers. Although Jussieu was the first to recognize the family 'Convolvuli', he did not place Porana there, instead putting it in the 'incertis sedis' group. He suggested comparing Porana to Ehretia P. Browne (Boraginaceae).

Lamarck (1804) paraphrased the preceding three treatments and echoed Jussieu's suggestion of a relationship between Porana and Ehretia. The generic concept to that time was based solely on $P$. volubilis and it is of a plant with a branched style, capitatereniform stigmas, a 2-valved capsule, and an accrescent and persistent fruiting calyx.

Palisot de Beauvois (1804) named Porana acuminata from "Oware" [Nigeria]. Although the species was later transferred to Neuropeltis Wall. (Bentham, 1849), Palisot de Beauvois' work is noteworthy because he was the first to recognize Porana as a member of the family Convolvulaceae.

Brown (1810) did not treat Porana but he compared it to his new genus Breweria with the words, "a Porana, cui charactere proxima, distinguitur calyce fructifero non mutato, et habitu." And he diagnosed it from Bonamia, which later proved congeneric with Breweria, by saying, "quae a Porana differt solummodo calyce fructifero non mutato, ..." This is the first time that Porana, then with two species, was compared with Bonamia; more on this relationship below.

Roxburgh (1814) published $P$. paniculata and $P$. racemosa as nomina nuda, later (1819) validating the former name by publishing a description and illustrating the species with a coloured plate. Wallich (in Roxburgh, 1824) validated $P$. racemosa by publishing 
Roxburgh's description in the 'Flora indica'. Wallich also described $P$. grandiflora, a plant unknown to Roxburgh. Inclusion of these three taxa in Porana broadened the generic concept in terms of the habit, leaf venation, floral morphology and allometry, pistil characters, and fruit type.

Sweet (1825), recognizing that these three Indian species did not accord well with Burman's generic concept, took up Buchanan-Hamilton's manuscript name, Dinetus, and transferred $P$. racemosa into it, while suggesting that the other two Indian species, "will prove to be congeners of our plant [Dinetus racemosus]." Later, Sweet (1827) transferred P. paniculata into Dinetus. This was the first attempt to limit the generic concept of Porana to plants having a campanulate corolla, 2-branched style, and 2-valved fruit, all characters shared by $P$. volubilis and $P$. acuminata.

Gaudichaud (1829) described the monospecific genus Duperreya from the western coast of Australia. The protologue does not compare Duperreya with Porana and this connection was only made by Mueller (1868), after examining fruits of the Australian plant.

Choisy (1834) in the first part of his 'Convolvulaceae Orientales' reduced Dinetus to synonymy with Porana. Choisy's dissertation includes several anomalous statements regarding Porana. The generic description states that the ovary is unilocular, though in fact $P$. volubilis often has a bilocular ovary. Later Choisy recognized Duperreya Gaudich. as a genus distinct from Porana (Choisy, 1837, 1845).

Endlicher (1839) treated Dinetus and Euporana as infrageneric categories in Porana, though he did not designate a rank for them, nor did he name the species assigned to each. His diagnosis for Dinetus states, "Calycis pentaphylli foliola duo exteriora immutata, tria interiora post anthesim aucta." This is erroneous: no species of Porana has the outer two sepals unchanged while the inner three are accrescent. Furthermore, the type species of Dinetus, D. racemosus, has all five sepals accrescent and equal in size. Endlicher maintained Duperreya as a genus.

Wight (1843) first noted that $P$. volubilis differs from all other species of Porana in terms of its ovary: "The character of the genus Porana (of which I believe this is the type) is to have a 1-celled ovary, but in this species I have ascertained beyond all doubt, that it is 2-celled, with 2 erect ovules in each. If the other species have 1-celled ovaries then this must be removed from the genus." Wight (1850) examined this point again, and observed: " ... I was led to scrutinize the characters of the genus more closely than when publishing my figure of Porana volubilis and very unexpectedly found that that plant, so far as the characters derived from the style, stigmas, and ovary show, is a genuine species of the more modern genus Breweria [now Bonamia], as a comparison of ... that figure (No. 347) ... with those of the accompanying figure, No. 1370, of Breweria Roxburghii, will at once show." Wight went on to say that a major nomenclatural upheaval would ensue if Breweria were synonymised with Porana and all the species of the former were transferred to the latter. Likewise Dinetus would have to be restored to accommodate the species of Porana other than $P$. volubilis. However, Wight was uncertain that the plant he illustrated as figure 347 was indeed $P$. volubilis: Wight's copy of Burman's 'Flora indica' lacked plate $21 *$ so he was unable to verify his living material against the original illustration of $P$. volubilis and Burman's description, as noted above, was lacking in critical details. Wight (1850) was aware that his own figure 347 (Wight, 1843) had been cited by Choisy (1845) as illustrative for $P$. volubilis, but 
he declined to initiate any taxonomic changes on those grounds. The recognition that $P$. volubilis shares several characters with Bonamia spp. was forgotten.

Mueller (1868) reduced the genus Duperreya to synonymy with Porana after he examined fruiting material collected by Drummond in Western Australia. This was the first time the Australian Duperreya was considered congeneric with Porana.

Bentham (in Bentham \& Hooker, 1876) placed Dinetus and Duperreya in synonymy with Porana, having earlier (Bentham, 1849) transferred the African P. acuminata to Neuropeltis. Bentham's account of Porana was copied almost verbatim by Baillon (1891) into his 'Histoire des Plantes'.

Clarke (1883) discussed the relationships of three Indian taxa, P. racemosa, P. malabarica, and $P$. truncata. He recognized them at species rank based on their distinctive fruiting calyces and utricle shapes. This constitutes the first recognition of the 'Dinetus' species group.

Peter (1891) divided Porana into three sections: Euporana (1 sp.), Duperreya (1 sp.), and Dinetus (8 spp.).

Hallier (1893) prepared a detailed generic description for Porana including the first anatomical and pollen characters. His generic concept of Porana was the broadest to date (including Dinetus and Duperreya as synonyms), with nine Asian, two African, one Australian, and one Mexican species.

The early twentieth century saw the publication of several new species of Porana, including the first from China (Gagnepain \& Courchet, 1915a). Gagnepain \& Courchet (1915b) included some Chinese taxa in a key to the Indo-Chinese species, which gave a perspective on all the east Asian taxa of Porana and broadened the generic concept yet further.

Schneider (1916) attempted a comprehensive revision of Porana though World War I precluded access to botanical literature and specimens of four species. Nonetheless, he named three new Asian taxa. Schneider retained Duperreya as a monotypic genus and treated 11 species and one variety in Porana. Three subgenera were recognized based on the number of ovules and the shape of the stigmas. The subgenus Euporana (lianas with 4-ovulate ovaries and globular stigmas) contained five species, the subgenus Dinetus (herbaceous twiners with 2-ovulate ovaries and ellipsoidal stigmas) contained five species plus one variety. For the first time $P$. paniculata was not included in Dinetus but was placed with $P$. volubilis in the subgenus Euporana [Porana]. The subgenus Pseudodinetus (herbaceous twiners with 2-ovulate ovary and globular stigmas) contained only $P$. dinetoides. The latter species is intermediate between the two subgenera and Schneider chose to recognize a new subgenus for it. Schneider relied heavily on ovule number as a taxonomic character and the species known to him do sort out well using this feature.

Gagnepain (1950) described the genus Tridynamia from a single collection made in Annam and remarked that the much accrescent sepals placed it in the Poraneae, although the simple style and entire stigma were exceptional for that tribe, evidently a comparison with $P$. volubilis, which has a bifid style and two capitate-reniform stigmas.

Roberty (1952) published 'Genera convolvulacearum', which established many new names at the rank of genus and above. In the tribe Poraneae, for example, he recognized seven genera including Porana. Two of these genera had earlier been synonymised with Porana, and two, Poranopsis and Dinetopsis, were therein segregated from it 
for the first time. In recognizing so many genera, Roberty brought Porana near to its original circumscription, including only $P$. volubilis and $P$. densiflora (= Metaporana densiflora). Yet this generic concept is unsatisfactory because $P$. densiflora lacks the generic characters that define Porana and the tribal characters of accrescent calyx and utricular fruit. To make matters worse, Roberty included Turbina Raf. in the tribe. While it is true that Turbina has an indehiscent, usually 1-seeded fruit, with a tough pericarp and an accrescent calyx, features all similar to those found in the Poraneae, its pantoporate and spinose pollen, dichasial inflorescences, and the ligneous rather then papery pericarp indicate a placement in the tribe Argyreieae Hallier f. Roberty (1964) published an emendation to his classification and typified the generic names he had published in 1952.

Melchior (1964) claimed 20 species of Porana in Asia and Australia and also three in Africa. This reference to African taxa must hark back to older concepts for the genus, because by 1964 the African taxa described in Porana had been transferred to Neuropeltis, Turbina, and Metaporana.

Verdcourt (1971) erected the genus Cordisepalum for one of two Asian taxa formerly considered congeneric with the Madagascan genus Cardiochlamys, and transferred the second into Porana. Verdcourt acknowledged the great similarity between Cordisepalum and the Porana species centred on Porana paniculata, yet felt the distinctive features of the gynoecium warranted generic rank.

Two floristic accounts of Chinese Convolvulaceae (Fang \& Huang, 1979a, b) increased the number of Porana taxa known from China and provided keys and commentary (in Chinese) on relationships within the genus. Huang Suhua prepared the treatments for Porana in both accounts (pers. comm., 1985).

\section{MORPHOLOGY}

In the discussion that follows Porana refers to the greatly narrowed generic concept adopted in this revision (2 spp.); Dinetus, Duperreya, Poranopsis, and Tridynamia are the four genera segregated from Porana s.l., and Cordisepalum is maintained as a distinct genus closely related to Poranopsis. Two informal subgroups within Dinetus are herein referred to as the 'Dinetus' species group and the 'Dinetopsis' species group.

\section{Habit}

All plants are stem twiners or, if no support is available on which to twine, prostrate in growth form. Cordisepalum, Duperreya, Porana, Poranopsis, and Tridynamia are perennial, suffrutescent climbers with woody lower stems and herbaceous shoot tips. Dinetus is exclusively herbaceous: the species in the 'Dinetopsis' species group are perennial while those in the 'Dinetus' species group appear to be annuals or perennials. Duration in Dinetus taxa seems to depend upon the climatic regime under which the plants grow. In temperate climate areas or at high elevations the plants die off during cold weather, and herbarium labels do not record whether they persist for a second year. In areas without a killing cold season the plants are recorded as perennials.

\section{Roots}

The root system is fibrous without an evident taproot in Porana and Poranopsis. The genus Dinetus has at least two types of root systems. Dinetus racemosus and 
D. truncatus have fibrous root systems. Dinetus duclouxii differs from its congeners by having enlarged, conical (fascicled?) roots with three to twelve segments that are "rich in starch" (ex label Veget. Team Chengdu Biol. Inst. 5262 at HBC). This same species may at times have a prominent taproot (ex Handel-Mazzetti 7041 at WU). The root system is unknown for Cordisepalum and Tridynamia.

\section{Stems}

The stem is cylindrical, dextrorsely twining, or prostrate or pendent if no support is available on which to climb. The pendent growth form occurs when the plants grow on steep rock faces or cliffs (e.g., Poranopsis sinensis, Tridynamia sinensis). The genera Cordisepalum, Poranopsis, and Tridynamia have striate or fissured bark, tan to brown or grey-brown in colour, with a corky outer surface. Porana has faint striations on the bark, which is dotted with whitish, elliptical lenticels. Dinetus stems are herbaceous, terete, and do not develop bark. Duperreya may have a few scattered lenticels on otherwise smooth stems; only the extreme base is woody and may be verrucate or have a thin, peeling bark.

\section{Indumentum}

A variety of trichome types is found. The most frequently encountered type is the malpighiaceous, or 2-armed hair (Fig. 1). This type is 2-celled, with a small stalk cell and a large terminal cell. The cells have smooth outer surfaces, thin walls and large
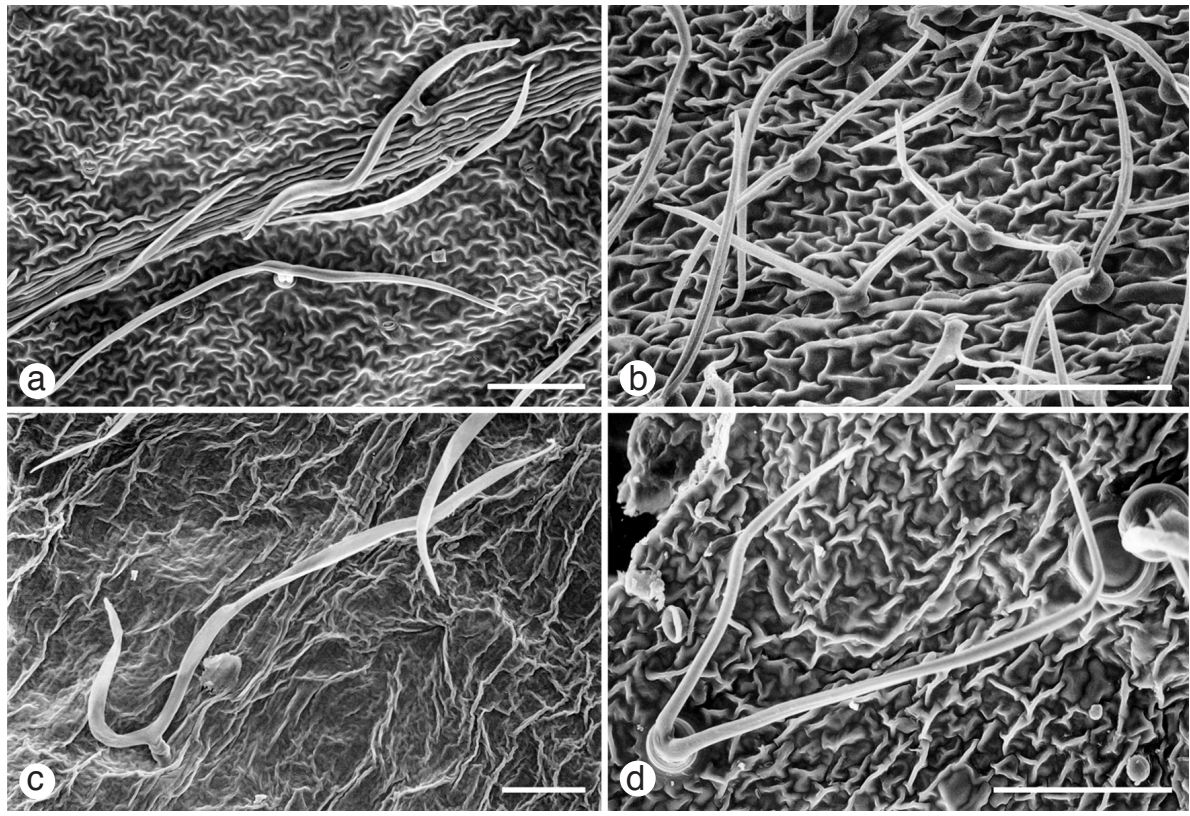

Fig. 1. Trichome morphology: 2-armed trichomes. - a. Duperreya commixta, appressed, equal-armed trichomes from abaxial sepal surface; b. Poranopsis paniculata, patent, equal-armed trichomes from adaxial leaf surface; c. Duperreya sericea, appressed, unequal-armed trichome from corolla interplica; d. Cordisepalum thorelii, erect, equal-armed trichome from adaxial leaf surface (a: Mitchell N657a; b. living material; c: George 11533; d: Chevalier 30976). Scale bar $=100 \mu \mathrm{m}$. 


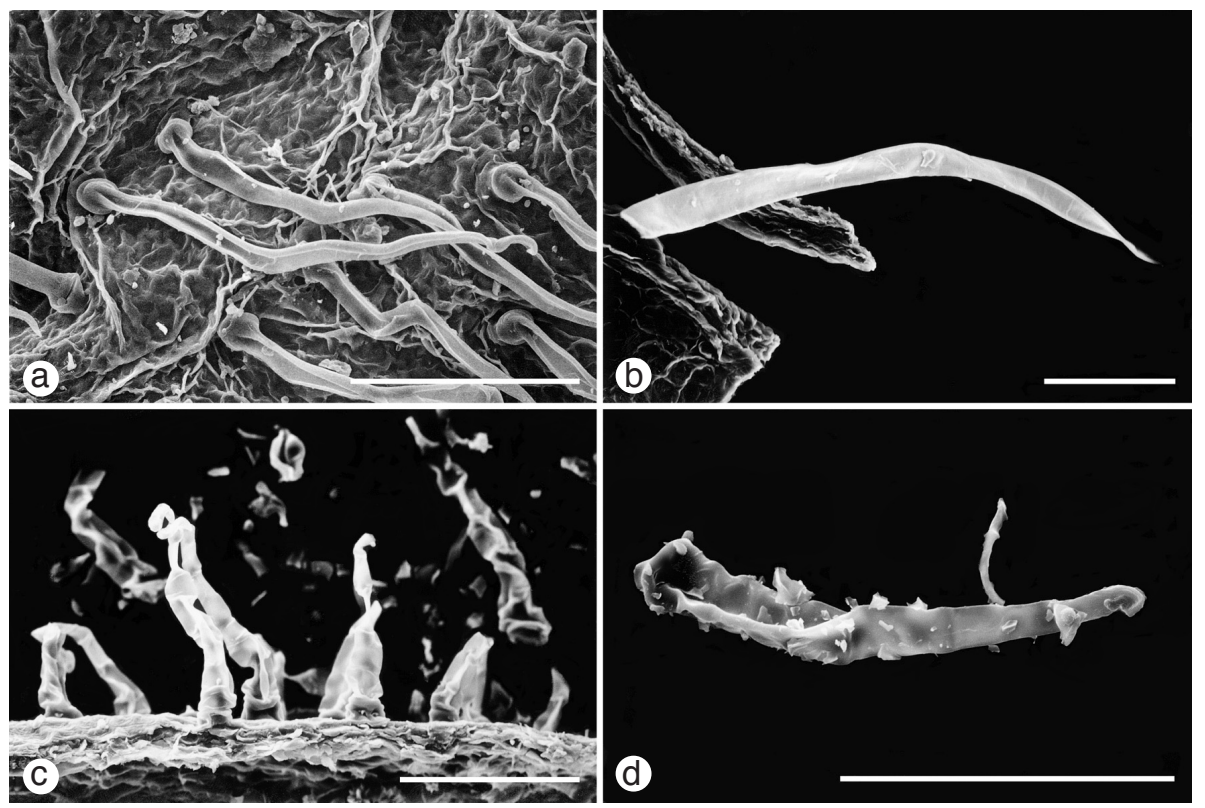

Fig. 2. Trichome morphology: simple and glandular trichomes. - a. Porana volubilis, simple trichomes from corolla interplicae; b. Dinetus dinetoides, simple trichome from stamen filament base; c. Poranopsis discifera, glandular trichomes from outer wall of utricle; - d. glandular trichome of P. discifera (a: O.E. White 123; b: A. Henry 9340; c, d: Poilane 26910). Scale bar = $100 \mu \mathrm{m}$.

lumina. The terminal cell bears two elongate arms, which may be straight or crimped and curly, appressed, ascending or erect in orientation, and equal or unequal in size. Cordisepalum, Dinetus, Duperreya, Poranopsis, and Tridynamia have predominantly 2-armed hairs.

Simple hairs occur in most genera (Fig. 2), though typically they are restricted to specific organs of some species. These simple hairs are 2-celled, with a very small stalk cell and a large terminal cell. The cells are usually thick walled and the lumina small. The terminal cell varies from subterete, as in Dinetus duclouxii, to deeply sulcate, as in Porana volubilis. Porana volubilis has exclusively simple hairs (Fig. 2a). Simple hairs have been observed on the pistil of Tridynamia sinensis, the axial parts of Cordisepalum phalanthopetalum, and on the leaves and bracts of most species of Dinetus. Pilose simple hairs also appear on the staminal filaments of Dinetus dinetoides (Fig. 2b) and various vegetative organs of Dinetus spp. (Fig. 3).

Stellate hairs are found only on the leaves and bracts of some species of the genus Dinetus (Fig. 3). The stalk cell is small with 3 arms radiating from it. The arms are typically erect and unequal in length.

Glandular hairs are of several types and are sporadic in their occurrence (Fig. 2, 3). Multicellular stalked glandular hairs occur on the leaves and bracts of Dinetus grandiflorus (Fig. 3d). Multicellular simple glandular hairs are found on virtually all vegetative parts of Dinetus duclouxii (Fig. 3c). The latter hair type also occurs on the outer fruit wall of Poranopsis discifera (Fig. 2c, d), the only instance of simple hairs in that genus. 

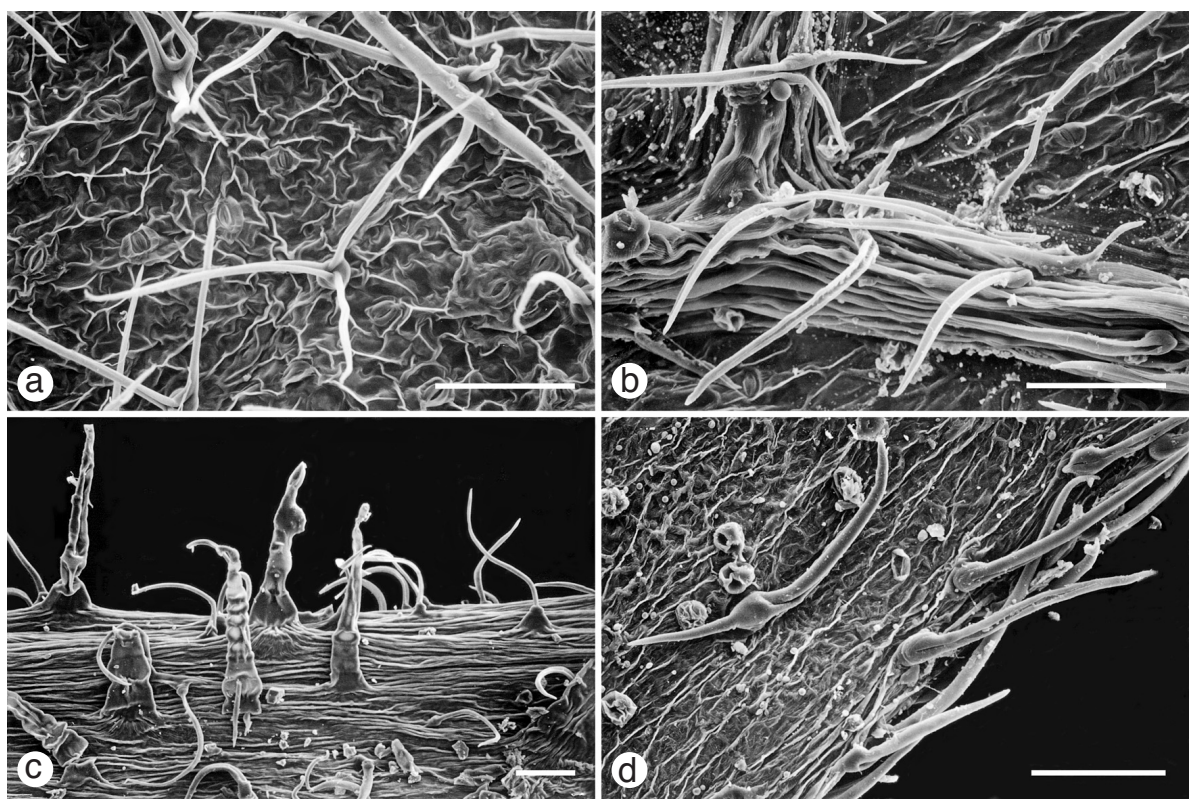

Fig. 3. Trichome morphology in Dinetus species. - a. D. truncatus, 3-armed trichomes from abaxial leaf blade; b. D. truncatus, distribution of simple and 3-armed hairs on abaxial veins and lamina; c. D. duclouxii, simple and glandular trichomes from inflorescence axis; d. D. grandiflorus, simple, glandular, and 3-armed trichomes from inflorescence bract edge (a, b: Staples et al. 425; c: HandelMazzetti 7041; d: T. Thomson s.n.). Scale bar $=100 \mu \mathrm{m}$.

\section{Leaves}

The leaves of all taxa form a homoblastic series, with the upper leaves and bracts like the cauline leaves in shape, only smaller and often more attenuate apically. All are bifacial, entire (lobed in Dinetus duclouxii), herbaceous to stiffly chartaceous in texture, and provided with a dense to sparse indumentum.

The leaves are petiolate, with a long to short petiole. The uppermost bracts and bracteoles become sessile since the petioles gradually diminish in length toward the stem apex. A basal pulvinus is present, though often weakly developed, in the petioles of Cordisepalum, Poranopsis, Tridynamia, Porana volubilis and some species of Dinetus. No conspicuous pulvinus is present in the petiole of Duperreya commixta, Duperreya sericea, and some species of Dinetus. Terete petioles occur in D. commixta, D. serice a and Cordisepalum species; they are terete to flattish in Poranopsis. Petioles are terete to compressed and sulcate adaxially in Tridynamia. The petiole in Dinetus is terete or compressed and sulcate adaxially.

Blade shape varies. Porana volubilis has ovate leaves with a truncate, emarginate, or subcordate base (Fig. 4e). The Australian Duperreya species (Fig. 4c) have linear to oblong blades with rounded or cuneate bases. Species of Cordisepalum, Dinetus, Poranopsis, and Tridynamia have cordiform blades with cordate bases (subcordate to truncate in Tridynamia sinensis var. delavayi) (Fig. 4d). The basal sinus may be deep, in which case the auricles often approach or overlap, or shallow, with the auricles 

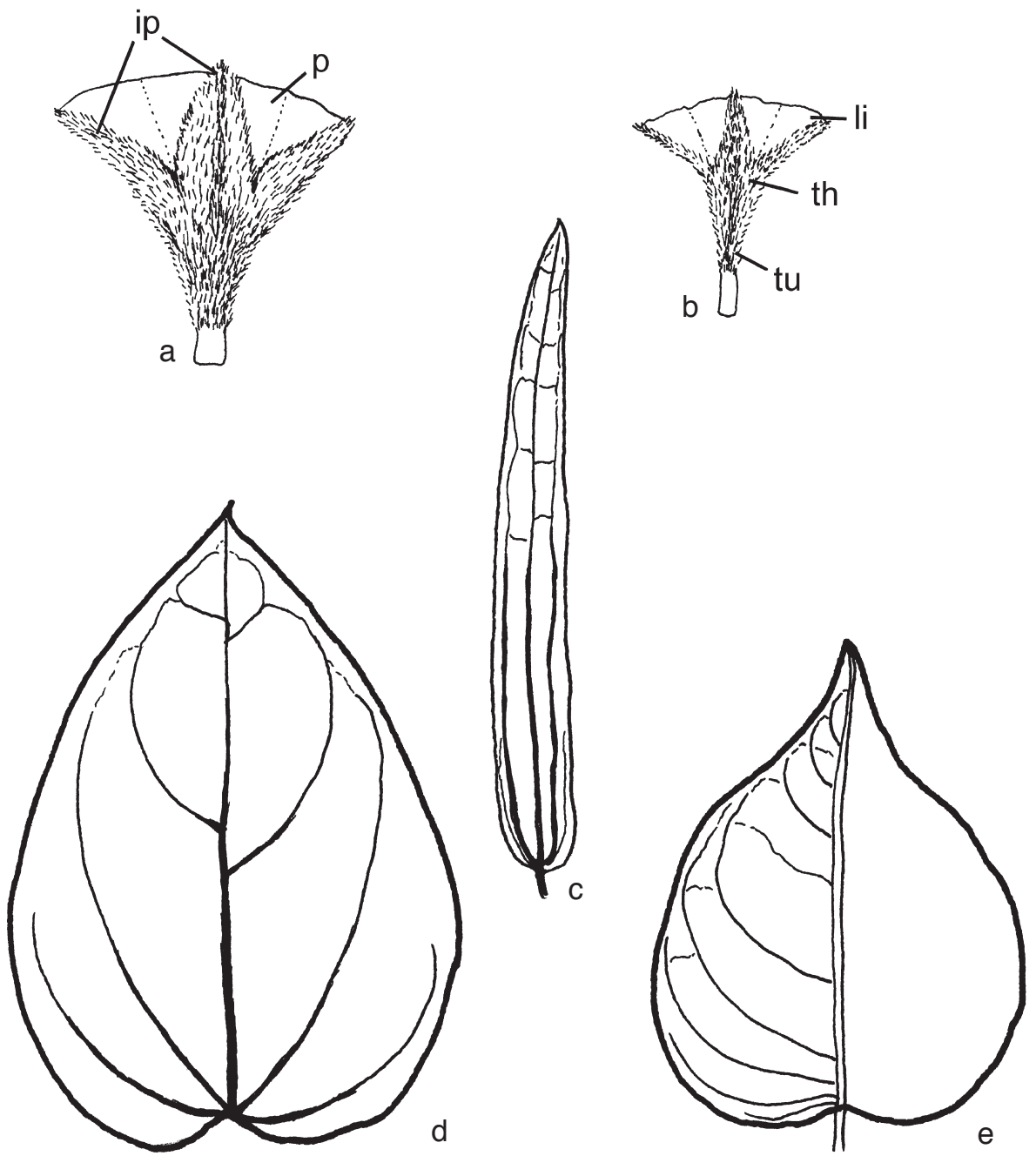

Fig. 4. Corolla and leaf blade morphology. - a. Corolla of Tridynamia megalantha, ip = interplica, $\mathrm{p}=$ plica; $\mathrm{b}$. corolla of Tridynamia spectabilis, $\mathrm{tu}=$ tube, $\mathrm{th}=$ throat region, $\mathrm{li}=\mathrm{limb}$; . leaf of Duperreya sericea with one strong pair of basal secondary veins; d. leaf of Tridynamia spectabilis with pedate venation; e. leaf of Porana volubilis with pinnate venation (a: King's collector s.n. in 1884; b, d: A.F.G. Kerr 10223; c, e: living material).

distant. The blades are entire, except for Dinetus duclouxii, which often has incised or lobed leaves (Fig. 9n). Blade shape may vary markedly on a single individual and these differences are not taxonomically meaningful.

\section{Leaf venation}

Three venation patterns are found in these genera and leaf venation is a taxonomically useful character at the generic level. Pinnate leaf venation is found only in Porana (Fig. 4e). This venation type is distinctive and sets $P$. volubilis apart from all other 
species formerly assigned to Porana s.l. The midvein gives rise to 5-8, usually 6 or 7 , pairs of secondary veins evenly distributed along its length. The secondary veins are arranged in a brochidodromous pattern. Pedate leaf venation is found in Cordisepalum, Dinetus, Poranopsis, and Tridynamia. Because rather few taxa of Convolvulaceae are presently known to have pedate leaf venation this is a useful taxonomic character for recognizing the genera segregated from Porana s.l. In the pedate arrangement the midvein usually has two well-developed pairs of basal secondary veins (Fig. 4d, 7-9, 12). The lowermost pair often branches immediately, thus giving the appearance of three basal pairs of secondaries. From 1-3 weaker pairs of secondaries depart from the midvein between its midpoint and the apex of the blade. These distal secondary veins are arranged in a brochidodromous pattern. Duperreya species have a third venation type. A single pair of secondary veins departs from the midvein near the blade base (Fig. 4c). A few weak secondaries also depart near the apex of the blade. This venation pattern, correlated with the linear blade shape found in these xeromorphic desert species, could be developed by reduction from either a pinnate or a pedate pattern.

\section{Inflorescence}

The raceme is the fundamental type of inflorescence in all genera. Simple racemes have been reduced to solitary flowers, and by aggregation have given rise to more complex types of inflorescences. Anthesis proceeds acropetally in all cases. Each node of the inflorescence is subtended by a bract. Bract refers to laminar structures that subtend a branch of an inflorescence or two or more flowers; bracteole refers to the laminar structure(s) immediately below a single flower. The lowermost bracts can be quite large and foliaceous whereas the uppermost bracts are frequently reduced to scales. Inflorescences are axillary in position, or they may terminate a lateral branch. Due to the large size of the lianoid species it is sometimes difficult to recognize the axillary position of the inflorescences from herbarium specimens. A single inflorescence is produced in each axil of Cordisepalum, Porana, Poranopsis, and Tridynamia. Paired inflorescences, with one larger than the other, are common in Dinetus.

Simple racemose inflorescences are found in Cordisepalum, Dinetus, and Tridynamia. More complex paniculate inflorescences are found in Cordisepalum, Dinetus, Poranopsis, and Tridynamia. Thyrsiform panicles are found in Porana (P. volubilis) and Cordisepalum phalanthopetalum. Solitary flowers are usual in Duperreya. In general there is a correlation between diminishing flower size and increasing complexity of the inflorescence: $C$. phalanthopetalum has the smallest flowers and the most congested thyrses, whereas Dinetus (D. grandiflorus) and Tridynamia (T. megalantha) have the largest flowers, which are borne, typically, in simple racemes.

A brief explanation about terminology is needed regarding the terms pedicel and bracteole. In developmental terms, the penultimate axial structure in an inflorescence is the peduncle, supporting one or more ultimate axes - pedicels - bearing a single flower each. The node between the peduncle and pedicel(s) bears one or more bracteoles. Among plants treated here the true pedicel is mostly absent, as indicated by the position of the bracteoles immediately below the calyx. Only Porana volubilis has both a true peduncle and a pedicel, with two scalelike bracteoles at the node between them. All species now assigned to Cordisepalum, Dinetus, Duperreya, Poranopsis, and Tridynamia have only a peduncle, morphologically speaking. However, in general 

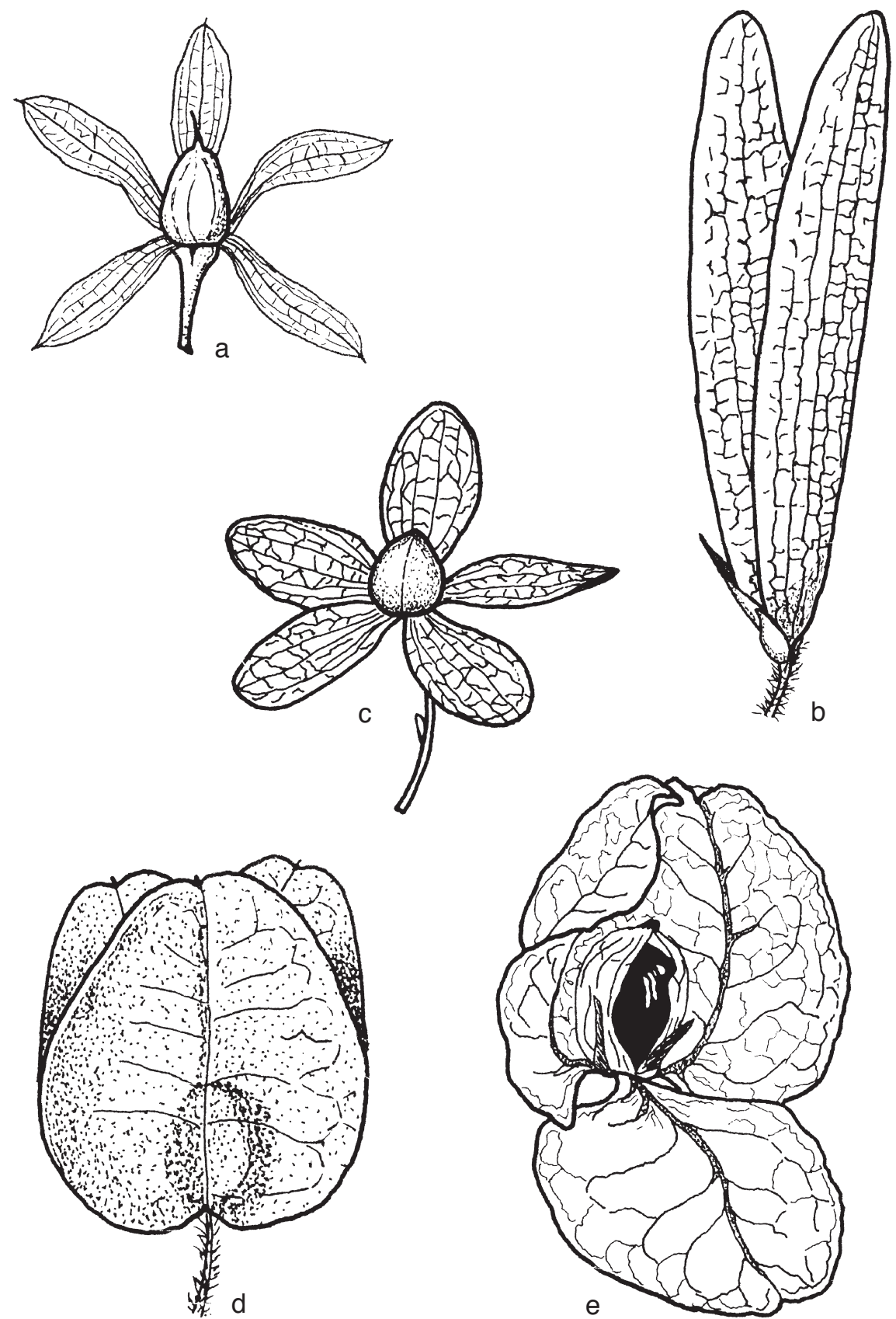

c
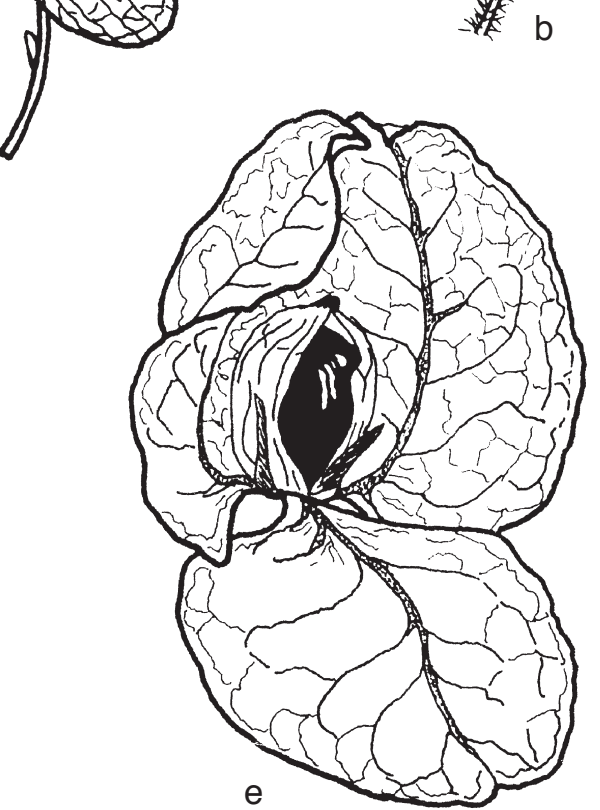

Fig. 5. Utricle and fruiting calyx morphology (not to scale). - a. Dinetus racemosus; b. Tridynamia sinensis; c. Porana volubilis; d. Cordisepalum thorelii; e. Poranopsis sinensis (a: redrawn from Wight, 1850: t. 1376; b: redrawn from Zhongguo ke xue yuan, 1974: 538, t. 5030; c: photos and Poilane 5332; d: redrawn from Gagnepain \& Courchet, 1915b: 296, f. 33; e: redrawn from Verdcourt 1971: 139, f. 1). 
botanical usage 'pedicel' has come to refer to the stalk of a single flower and that is how it has been used in the descriptions following.

\section{Bracteoles / Calycle}

The absence of a true pedicel means that the bracteoles are borne immediately below the calyx, forming a calycle when the bracteoles are developed in a sepaloid manner. Two sepaloid bracteoles occur in Duperreya species and three in Tridynamia. The bracteoles are reduced to scales in other genera: two in Poranopsis, three in Cordisepalum, and two or three in Dinetus. In some species the scale-like bracteoles undergo enlargement during fructification, becoming more prominent in fruit, e.g. Dinetus grandiflorus. Dinetus duclouxii differs from other Dinetus in having three sepaloid bracteoles in flower that persist and enlarge in fruit.

\section{Calyx}

The calyx consists of five sepals that are accrescent and chartaceous in fruit (Fig. $5)$. The developmental variations on this basic theme provide the morphological characters that have historically been of the most taxonomic value in classifying this group of plants. In the descriptions that follow emphasis is given to the readily observable outer sepals; where the inner sepals are concealed by the outer ones, they are generally similar to them but the texture is more delicate and the indumentum sparser.

Porana and Duperreya have free, subequal, quincuncial sepals. The calyx is large relative to the corolla: at anthesis the corolla varies from just longer than the calyx to twice as long as the calyx. In fruit (Fig. 5c), all five sepals enlarge equally (unequally in the Mexican Porana nutans) and at maturity loosely clasp (Duperreya), or become reflexed from $(P$. volubilis) the fruit. The fruiting sepals have several weakly developed, parallel, longitudinal veins that form a reticulum near the apex; no single vein reaches the apex. No midvein is evident (Fig. 6a).

Tridynamia has free, unequal, quincuncial sepals that are small in proportion to the corolla. In fruit (Fig. 5b), all five sepals enlarge, but the outer two or three are proportionately much larger than the inner ones. The fruiting sepals are thickly chartaceous to subcoriaceous in texture, and the sepal bases tightly enclose the fruit, flaring out and becoming flat and wing-like apically. The sepals have multiple, parallel, longitudinal veins arising at the base. Three of these veins usually reach the apex, the remainder fade out along the margins (Fig. 6e).

Cordisepalum and Poranopsis have free, subequal, quincuncial sepals that are small to tiny in proportion to the corolla. In fruit all five sepals enlarge and the outer three become much larger then the inner two. The texture is thinly chartaceous, often reticulate, and the outer sepals loosely clasp the fruit ( $P$. paniculata, $P$. discifera) or form a bladdery 'pod' around it. In P. sinensis (Fig. 5e) the lower halves of the outer three sepals cohere along their margins where curly hairs on the inner (adaxial) faces tangle together. In $C$. thorelii (Fig. $5 \mathrm{~d}$ ) the sepal margins are free. The venation pattern is distinctive for these genera (Fig. 6c, d). A single prominent midvein extends to the apex. Numerous pinnately arranged secondaries depart from the midvein, looping back within the margin and anastomosing in a semi-brochidodromous pattern. The secondaries give rise to a reticulum of tertiary veins.

Dinetus has equal or unequal sepals that are tiny in proportion to the corolla. Aestivation varies in this genus, and due to the minute size of the flowering sepals it is 

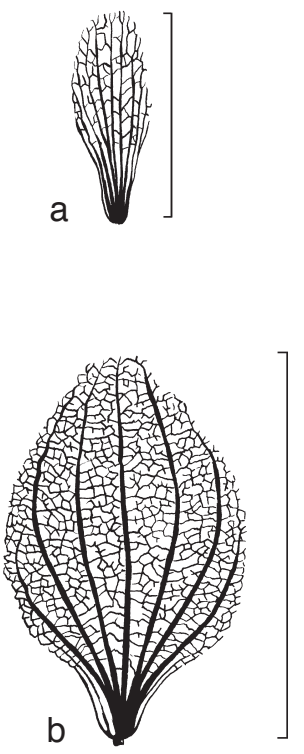

C
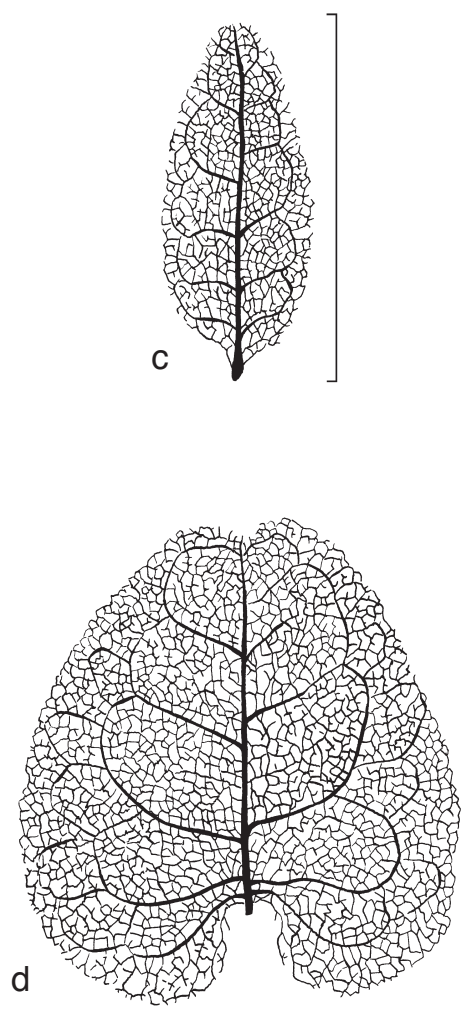

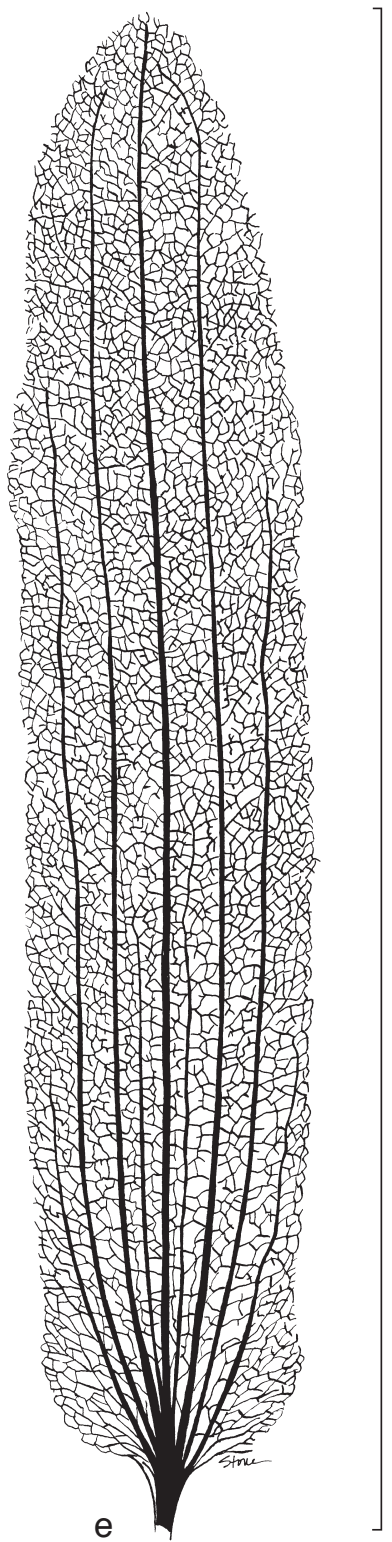

Fig. 6. Cleared and stained outermost sepals demonstrating venation patterns. - a. Porana volubilis; b. Dinetus rhombicarpus; c. Poranopsis paniculata; d. Cordisepalum thorelii; e. Tridynamia sinensis var. sinensis (a: Poilane 5472; b: Mrs. Strait (sub F.G. Dickason) 7706; c: Dar et al. s.n.; d: Poilane 8768; e: $C$. Wang 40898). Scale bars: $\mathrm{a}=9 \mathrm{~mm}$; b, $\mathrm{c}=1.7$ $\mathrm{cm} ; \mathrm{d}=2.1 \mathrm{~cm} ; \mathrm{e}=6.8 \mathrm{~cm}$. 
difficult to discern. The fruiting calyx displays the aestivation clearly. The 'Dinetus' species group has sepals that are slightly fused at the base and the aestivation is valvate. The 'Dinetopsis' species group has free sepals that are quincuncial in aestivation (D. duclouxii, D. grandiflorus) or slightly gamosepalous and valvate (D. decorus). The fruiting calyx of the 'Dinetus' species group (Fig. 5a) has all five sepals equally enlarged, reflexed from the fruit or loosely clasping it at maturity, thinly chartaceous in texture, with nine parallel, longitudinal veins arising at the sepal base and three veins reaching the apex. No midvein is evident; all veins are developed more or less equally (Fig. 6b). Two species of the 'Dinetopsis' species group, D. grandiflorus and D. duclouxii, have the three outer sepals enlarged more than the inner two, the fruiting calyx loosely clasps the fruit at maturity, the texture is more stiffly chartaceous, and the venation has the median vein slightly more prominent than the others. Dinetus decorus, the third species belonging to the 'Dinetopsis' species group, has fruiting sepals like those in the 'Dinetus' group.

\section{Corolla}

The corolla is sympetalous and consists of five petals fused basally into a tube, and either free or fused apically. The aestivation of the apical portion varies, and can be taxonomically informative.

Terminology for the regions of the convolvulaceous corolla varies from author to author. The terms employed here follow. The tube (Fig. 4b) is the lowermost part of the corolla, which may be short or quite long, and is usually narrow. The throat (Fig. 4b) is the area where the tube begins to widen out into the limb. Widening may be either abrupt or gradual, and the throat can thus be almost nonexistent or quite extensive, respectively. The limb is often presented at an oblique angle to the tube, or it may be reflexed or perpendicular to the tube. The limb varies from entire to toothed, lobed, or parted (Fig. 4b).

Two distinct regions are formed on the corolla limb due to the aestivation in the bud stage. Five thinner hyaline areas that are folded inside the bud are the plicae (Fig. 4a). At anthesis the plicae form the thin, translucent areas of the corolla limb. Alternating with them are five slightly thicker areas, the interplicae (Fig. 4a) sensu Myint \& Ward (1968), containing the vasculature and forming the exposed outer surface of the bud. The interplicae are equivalent to the 'midpetaline bands' or 'midpetaline lines' of Van Ooststroom (1934), O’Donell (1941), Van Ooststroom \& Hoogland (1953), and Robertson (1971).

Indumentum distribution varies on these regions of the corolla. In general, the inner (adaxial) surface of the entire corolla is glabrous, except for specialized hairs present on the filament bases in some species (Fig. 2b). The plicae are glabrous on the outer (abaxial) surface as well. But the external corolla surfaces of the tube, throat, and limb have varying distributions and densities of hairs, and these are often taxonomically informative characters. Dinetus, for example, has an apical tuft of hairs at the tips of the interplicae, the corolla is otherwise glabrous, which immediately sets this genus apart from all other plants considered here.

Aestivation of the limb varies and can be taxonomically informative. Porana has a campanulate corolla with plicate and valvate aestivation. Poranopsis has a funnelform corolla with valvate aestivation. Cordisepalum has a rotate corolla with valvate to 
contortuplicate aestivation; the degree of twisting of the limb in bud seems to increase with corolla size. Dinetus has a funnelform to subsalverform corolla with contortuplicate aestivation of the corolla lobes in bud. Duperreya has a campanulate or broadly funnelform corolla with contortuplicate aestivation of the lobes in bud. Tridynamia has a campanulate to broadly funnelform corolla with contortuplicate aestivation. Thus two groups of genera can be recognized: those with unambiguously valvate corolla aestivation (no twisting evident in buds) and those with contortuplicate aestivation (buds show evident twisting); Cordisepalum has one species with each type of aestivation.

\section{Androecium}

There are five equal or unequal stamens arranged alternately with the petals. The lower part of each filament is flattened and adnate to the corolla tube. This basal area may be glabrous or provided with glandular or pilose hairs. Distally the filaments are free from the corolla and become terete and glabrous. The anthers are bilocular and dehisce laterally. Cordisepalum, Dinetus, Duperreya, Porana, and Poranopsis have ellipsoidal anthers that are introrse or extrorse. Tridynamia has sagittate anthers with diverging bases and versatile attachment to the filament. This feature is taxonomically diagnostic for Tridynamia.

\section{Pollen}

A separate paper with detailed pollen descriptions of all genera in the tribe Poraneae is under preparation, so only a summary is provided here. Descriptive terminology follows that proposed by Moore \& Webb (1978). The six genera recognized in this account have non-spinose pollen grains with smooth, psilate or finely granulate surface. Grains are small: no more than $35 \mu \mathrm{m}$ in their longest axis. The grains vary in shape from nearly spheroidal to oblate or prolate spheroidal, more rarely obtusely rectangular in some species of Dinetus. Apertures are typically 3 longitudinal colpi in most specimens of all taxa surveyed. Exceptional specimens of T. megalantha have 3- and 4-colpate grains in the same anther. Likewise some specimens of Duperreya commixta have 3-colpate and 3 -zonocolpate grains $(3$ polar $\times 3$ equatorial $\times 3$ polar colpi) in the same anther. Well-developed pilate, multi-angulate outgrowths are present inside the margins of the colpi in Cordisepalum, Poranopsis, and Tridynamia. The outgrowths are only weakly developed in Duperreya and Porana and absent in all species of Dinetus.

\section{Gynoecium}

The pistil is comprised of two carpels, fully fused except for the distal part of the style (Porana) and the stigmas in a few species. A disc may be present or not; this feature varies within individuals of a species and cannot be consistently used as a taxonomic character. The ovary is unilocular in Cordisepalum, Dinetus, Duperreya, Poranopsis, and Tridynamia. Some individuals of any of these genera, however, may have a vestigial basal septum in the ovary. Porana ( $P$. volubilis) usually has a bilocular ovary. Ovule number varies in most genera: Tridynamia has four ovules except $T$. bialata, which has two; Cordisepalum thorelii has a 4-ovulate ovary, though the only known collection of $C$. phalanthopetalum has five ovules in the ovary.

The style is simple in all genera, except for $P$. volubilis, which has a 2-branched style similar to those found in Calycobolus and Dipteropeltis. Fundamentally there are two stigmas, and their shape and degree of fusion are taxonomically informative. 
Porana has two globose, free stigmas. In Duperreya there are 2 reniform or cordiform stigmas that are partially fused at the base. Tridynamia has two subglobose stigmas, fused for part of their length, compressed either laterally or longitudinally, and coarsely wrinkled. Cordisepalum and Poranopsis have two globose stigmas that are partially fused and almost smooth. In Dinetus the two stigmas are almost fully fused, ellipsoidal to clavate in shape, with an emarginate or rounded apex, and a smooth surface. Dried stigmas of Dinetus are frequently coloured differently from the style; for example, the stigma may be grey and the style tan or yellowish.

Fruit

A 1-seeded fruit with a thin papery fruit wall that breaks open irregularly to release the seed is distinctive for this group of genera. This fruit type fits the technical description of an utricle (Lawrence, 1951; Radford et al., 1974). The style or the style base often persists in fruit, so that the utricle is apiculate. The accrescent calyx may tightly invest the utricle, loosely surround it, or be reflexed from it at maturity (Fig. 5). The utricle remains attached to the accrescent calyx in any case, and seems to comprise a dispersal unit.

Cordisepalum, Poranopsis, and most species of Dinetus have utricles with thin walls that closely conform to the shape of the seed. The utricle in $C$. thorelii is unusual in gradually tapering to a slender stalk at the base. Dinetus truncatus and D. rhombicarpus have an inflated utricle that is filled with a spongy matrix between the seed and the fruit wall. The calyx loosely surrounds or is reflexed from the utricles in these genera (Fig. 5, 8, 9, 12).

Utricles of Tridynamia species have a thicker, more stiffly chartaceous wall that is harder to break open. The lower calyx tightly encloses the utricle but distally the sepals flare out and become flat and wing-like (Fig. 5, 13). Fruits of Tridynamia are parasitized by insect larvae and the fruits thus affected have a particularly tough fruit wall that is often crustose and somewhat shiny on the inner surface.

Utricles of Duperreya are chartaceous to thinly coriaceous and conform closely to the shape and size of the single seed. The fruiting sepals loosely enclose the utricle and are only moderately enlarged, relative to their size at flowering (Fig. 11).

The fruit of Porana is somewhat larger than the seed and has a stiffly papery fruit wall that breaks open easily. Porana volubilis has a suture clearly visible in the fruit wall, which sometimes begins to split open from the base upward yet the utricle typically shatters irregularly. This species also occasionally has 2 -seeded fruits. The calyx is reflexed from the utricle (Fig. 5).

\section{Seed}

The single seed is usually ellipsoidal or subglobose, sometimes slightly asymmetrical at the base, with a basal circular hilum; the seed coat is hard, smooth, and glabrous. The embryo is erect, with a straight radicle and two foliaceous, multiplicate and corrugate cotyledons. Endosperm is scant and cartilaginous, turning mucilaginous upon hydration.

\section{Seedling}

Viable seeds were available for only three species. Voucher specimens of the seedlings or cotyledons were prepared and placed in the Arnold Aboretum herbarium (A). 
Duperreya sericea seedlings have two orbicular cotyledons with a deeply emarginate apex and are borne on a short hypocotyl.

Dinetus racemosus and $D$. truncatus have two ovate cotyledons that are apically acute or incised, margins entire, with palmate venation visible, borne on a short hypocotyl. These observations agree with a published illustration of the seedling of D. racemosus (Sweet, 1825: t. 127), but they disagree with recent studies of seedling morphology (Shenoy \& Inamdar, 1985). Since Shenoy \& Inamdar cited no voucher specimens for the plants that were their seed source it is impossible to verify their identifications. Their seedlings are not Dinetus, but appear to be some other member of the Convolvulaceae.

\section{DISTRIBUTION, HABITATS, AND PHENOLOGY}

When considered in the historical context, the distribution of Porana s.l. is centred on continental Asia. However, when the six genera (Porana s.s. and the five segregates) are considered separately the geographic distributions are more restricted. Duperreya is confined to xeric habitats in Australia. Tridynamia is centred in Southeast Asia, extending westward to northeast India and the Andaman Islands and north into subtropical China. Poranopsis has a very similar distribution pattern to Tridynamia, although one of its species extends westward much further along the southern flank of the Himalayas as far as Pakistan and northwest India. Porana extends from Southeast Asia through Malesia. Cordisepalum has the most limited distribution, being confined to Southeast Asia. It is the least well collected of the genera, however, and its distribution may be more extensive than presently understood.

Dinetus is unique among the segregates of Porana because it is found in much more temperate latitudes than the others. In tropical latitudes, Dinetus generally grows at higher elevations than the other genera. Because D. racemosus is a weedy camp follow, often associated with human activity that has surely enhanced its range, Dinetus has the greatest geographic distribution of any segregate of Porana: from India across Myanmar and Southeast Asia, north into China as far as southern Gansu and Shaanxi and northern Henan provinces, with widely disjunct populations in Indonesia on Java, Sulawesi (Celebes) and some of the Lesser Sunda Islands. One species, D. grandiflorus, just penetrates into Tibet, but no species of Dinetus (nor Poranopsis nor Tridynamia) crosses the Himalayan massif; instead the distribution follows the southern and eastern flanks of that mountain range.

Habitat information is summarized from herbarium specimen label data and personal observation of living plants in Asia. All taxa are climbing heliophytes that grow in sunny habitats or sunny situations in forested habitats. Three genera (Cordisepalum, Poranopsis, and Tridynamia) show a marked calciphilic tendency and are often collected from limestone or calcareous soils.

Dinetus species are herbaceous climbers from distinctly temperate climates and also from higher elevations in the tropics where conditions are more temperate, such as D. malabaricus in southwestern India's ghats at $1000-1500 \mathrm{~m}$, or D. racemosus on mountain peaks at 1300-2075 $\mathrm{m}$ in Java. The elevational range overall is from 900-3500 m. Dinetus has been collected from limestone soils but does not demonstrate 
the marked preference for them that the other genera do. In fact, Dinetus occurs on a wide range of soils, having been recorded from fertile loams, humus, and on rich red soils as well as sandy, granitic, schistaceous, silty, and clay soils.

Dinetus grow in diverse mesic habitats ranging from grasslands to forest margins and clearings, including scrub, thickets, understory, conifer-hardwood forest, cloud forest, deciduous forest, old cultivated land, roadsides, rocky hillsides and ravines, along watercourses and in waste places. Plants are summer to fall flowering, with fruits borne later in the same year.

Duperreya species are found in dry habitats and deserts of Western Australia with a widely disjunct population of $D$. commixta in east-central Australia. Although infrequently collected from crevices in limestone-conglomerate cliffs, neither species can be said to have a pronounced calciphilic tendency, and the majority of specimen labels record soil types such as red sands, sandy clay soils, or lateritic or granitic rocks. Both species are suffrutescent perennial climbers that are found mostly along watercourses as well as in various vegetation associations, forest margins, and on rocky slopes at elevations that range from sea level to $200 \mathrm{~m}$. They flower most heavily between August and October, with fruits developing in the weeks after.

The other four genera are woody lianas from more tropical latitudes, although individual species do extend the distribution for Poranopsis and Tridynamia into subtropical and warm temperate areas. Little is known about Cordisepalum, but the few specimens extant indicate the two species are low elevation (25-1200 m) woody climbers that grow at the margins of, or in clearings in, a variety of mesic or seasonally dry forest types, including hardwood, evergreen, and mixed/deciduous forests. The plants flower during the cool dry season (November and December) and bear fruit shortly thereafter.

Members of the genus Poranopsis are woody lianas that seem to have a marked preference for limestone soils, although one species, $P$. paniculata, has been collected on many other soil types as well. It is probably significant that $P$. paniculata is the only cultivated species of this genus, and it has not been easy to distinguish herbarium specimens made from cultivated plants grown on diverse soil types from those of wild origin, thus the calciphile tendency of wild plants may be more marked than it seems based on herbarium specimen label data alone. The habitats in which Poranopsis grows are diverse and include many types of seasonally dry forest, thickets, scrub, open plains, rocky hillsides, margins of cultivated land, and around human habitation (the latter two derive from collections of $P$. paniculata). Elevational data recorded by collectors suggest that most plants were found between 350 and $2000 \mathrm{~m}$, although cultivated plants seem to extend this downward to sea level. All species seem to flower after the end of the rainy season, throughout the cool dry season, with fruits ripening from the latter part of the cool dry season into the hot dry season.

Tridynamia taxa are also woody lianas that have a marked preference for calcareous soils between sea level and $1800 \mathrm{~m}$ elevation, rarely up to $2500 \mathrm{~m}$. A number of other soil types have been noted, including clay, schistaceous, lava beds, and rock ledges. Habitats include various forest types, prairies, grassy savannahs, stream banks, rock cliffs and steep slopes, and along roadsides, the margins of cultivated land, and near villages. There seems to be flowering almost year-round in the tropical species, with a peak from May to August; the subtropical to temperate T. sinensis shows a more pronounced summer flowering season with fruits maturing in the fall. 
The genus Porana has an amphi-Pacific distribution, with one species in Southeast Asia and one in Mexico. The Asian P. volubilis is a mesic forest species, primarily, and it has been collected from monsoon forest, coastal forest, as well as thickets, savannahs, along river banks, and on rocks at elevations ranging from sea level up to $500 \mathrm{~m}$. There is no evidence to support a limestone preference and label data indicate it has been found on diverse soil types including sandy, rocky, and 'rich red' soils. Because $P$. volubilis has long been associated with human activity, its distribution and apparent habitat preferences have surely been altered by human intervention. Porana volubilis seems to flower year round with a definite peak between April and August in Indonesia. As one moves further north away from the equator the flowering peak shifts to later in the year, and in Southeast Asia and the Philippines the flowering peak falls between October and January.

\section{TAXONOMY}

The following key will enable the identification of flowering and fruiting specimens of the six genera recognized here. The taxa are arranged alphabetically in the Taxonomic section. In the Phenology section the number of flowering/fruiting specimens studied is recorded by month.

1a. Leaves linear-oblong, with a single basal pair of secondary veins (Fig. 11); flowers solitary, axillary. - Xeric Australia . . . . . . . . . . . . . Duperreya

b. Leaves broader, with 3 or more pairs of secondary veins; flowers in racemose, paniculate, or thyrsiform inflorescences. - Asia and Malesia . . . . . . . . 2

2a. Leaf venation pinnate (Fig. 4e); calyx covering half or more of the corolla; style

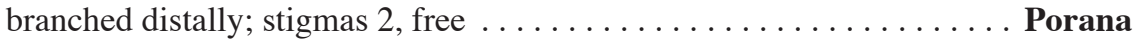

b. Leaf venation pedate (Fig. 4d); calyx covering $1 / 4$ or less of corolla tube; style entire or absent; stigmas 2 , partly or wholly fused $\ldots \ldots \ldots \ldots \ldots \ldots$

3a. Plants herbaceous; flower buds glabrous except for minute apical tuft of hairs; fruiting sepals all equally enlarged (unequally in $D$. grandiflorus). . . . . Dinetus

b. Plants woody (often with herbaceous stem tips); flower buds hairy externally; outer 2 or 3 fruiting sepals greatly enlarged, the others less so . . . . . . . . . 4

4a. Sepals unequal in flower; fruiting sepals with 3 to 9 parallel longitudinal veins

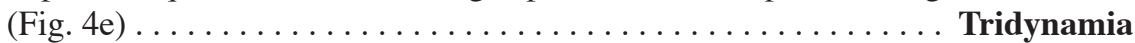

b. Sepals (sub)equal in flower; fruiting sepals with 1 midvein and a reticulum of fine

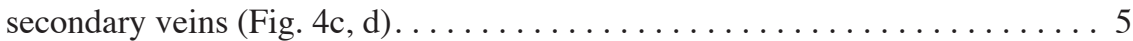

5a. Corolla funnelform, white, limb subentire to 5-toothed; utricle sessile on torus . . Poranopsis

b. Corolla rotate, yellowish, limb deeply 5-lobed or -parted; utricle raised on a slender stalk

Cordisepalum

\section{CORDISEPALUM}

Cordisepalum Verdc. (1971) 138. - Type species: Cordisepalum thorelii (Gagnep.) Verdc.

Lianas, lower stem woody, glabrescent, upper branches herbaceous, tawny or ferruginous, velutinous. Leaf petiole slender, terete, slightly pulvinate; blade ovate-cordate, 
entire, chartaceous; venation pedate, veins prominent abaxially. Inflorescence axillary, racemose, paniculate, or thyrsiform, anthesis proceeding acropetally; bracts foliaceous, texture, indumentum and venation like the leaves; bracteoles scale-like, attached just below calyx. Flowers small, numerous; sepals 5, free, quincuncial, clasping corolla tube base, unequally accrescent in fruit. Corolla rotate, tube short, limb 5-lobed or -parted to below middle, lobes reflexed at anthesis, valvate in bud. Stamens 5, equal, slightly exserted, filaments in lower half adnate to corolla tube, free and filiform above; anthers oblong, longitudinally dehiscent; pollen 3-colpate, nonspinose. Pistil included; disc not obvious; ovary unilocular, glabrous; ovules 4 (or 5), basal, erect; style simple or absent; stigma terminal, biglobose, lobes slightly longer than broad, coarsely wrinkled. Fruiting calyx enclosing utricle, outer 3 sepals greatly enlarged, subcircular or broadly ovate, base cordate, margins free, inner 2 sepals only slightly enlarged; sepals all thinly chartaceous, midvein 1 , finer veins reticulate, prominulous, dark. Utricle ellipsoid or fusiform, apiculate by persistent style, borne on a stalk developed from ovary base, velutinous. Seed 1, ellipsoid, smooth, glabrous; hilum basal, circular.

A genus of two species, endemic in Southeast Asia.

The genus Cordisepalum is similar in several characters to the genus Poranopsis and Verdcourt's comment (1971: 140) at the time he named the genus, “... my only doubt has been the wisdom or otherwise in separating it" is apt. The features that distinguish Cordisepalum from Poranopsis are the rotate, deeply parted corolla and the stalked utricle.

Gagnepain (in Gagnepain \& Courchet, 1915a), in naming Cardiochlamys thorelii, recognized the similarities between the Asian plant and the Madagascan genus Cardiochlamys and concluded that the former was a widely disjunct species of Cardiochlamys. He went on to differentiate his plant from the two Madagascan species, and it is in these differences that the characteristics allowing one to separate Cordisepalum from Cardiochlamys emerge. Species of Cardiochlamys are herbaceous twiners (including the stem base?) with slenderly funnelform corollas, well-exserted stamens, pantoporate pollen grains, biovulate ovaries, a thick stalk (gynophore) bearing the utricle, a prominent floral disc, and ovate-cordate fruiting sepals with acuminate-acute apices and adherent margins. While there are superficial similarities between these two genera, Cordisepalum can readily be distinguished on the basis of its rotate corolla, 3-colpate pollen grains, 4- (or 5-)ovulate ovaries, seeming lack of a floral disc, and fruit sepals that are free at the margins. Deroin (2004) has compared the floral anatomy of these two genera and shown that while a disc is not obvious in Cordisepalum, its presence can be demonstrated on histological grounds.

\section{KEY TO THE SPECIES}

1a. Inflorescence congested; flowers 3(-4) mm diam.; corolla lobes glabrous on the inner surface $\ldots \ldots \ldots \ldots \ldots \ldots \ldots \ldots \ldots \ldots \ldots$ 1. C. phalanthopetalum

b. Inflorescence lax; flowers (5-)7-11 mm diam.; corolla lobes velutinous on both surfaces $\ldots \ldots \ldots \ldots \ldots \ldots \ldots \ldots \ldots \ldots \ldots \ldots \ldots \ldots \ldots \ldots$. thorelii 


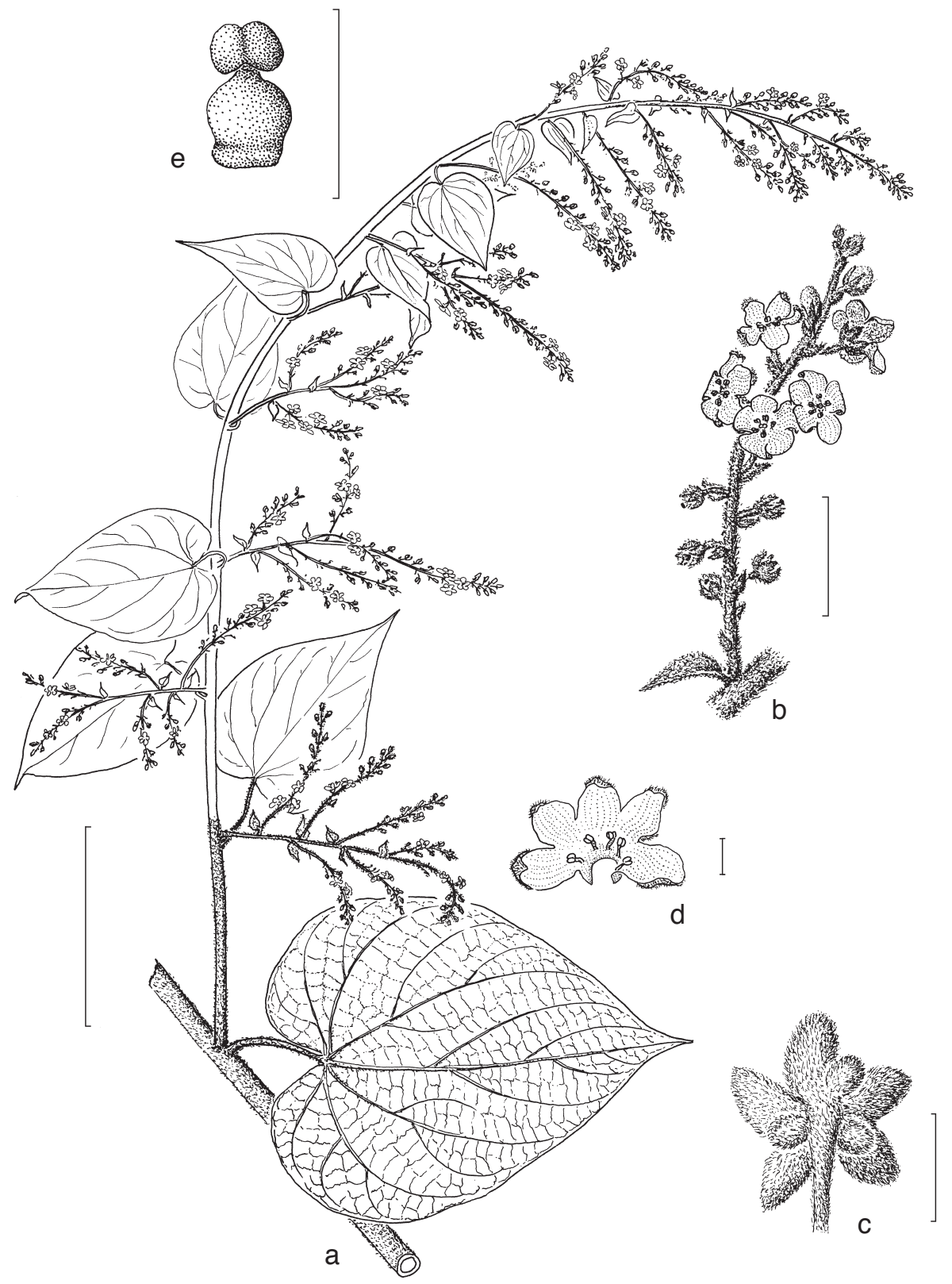

Fig. 7. Cordisepalum phalanthopetalum Staples. a. Habit; b. branch from the inflorescence; c. calyx and calycle; d. corolla opened, with stamens; e. pistil (all: Van Beusekom et al. 3791). Scale bars: $\mathrm{a}=5 \mathrm{~cm}, \mathrm{~b}=5 \mathrm{~mm}, \mathrm{c}-\mathrm{e}=1 \mathrm{~mm}$. 


\section{Cordisepalum phalanthopetalum Staples, spec. nov. - Fig. 7; Map 1}

Suffrutex volubilis, affinis $C$. thorelii, sed a inflorescentiis densioribus, floribus parvioribus (ad $3 \mathrm{~mm}$ diametro), corollis rotatis 5-partitis lobis intra glabris extra dense velutinis, et stigmatibus biglobosis sessilibus, differt. - Typus: C.F. van Beusekom, C. Phengklai, R. Geesink \& B. Wongwan 3791 (holo BKF; iso BISH, C, K, KYO, L, MO, P), Thailand (SW), Kanchanaburi: along track from Huay Bankan to Si Sawat, $14^{\circ} 50^{\prime} \mathrm{N}, 98^{\circ} 50^{\prime} \mathrm{E}$, 15 Nov. 1971.

Liana; vegetative parts tawny to brownish hairy; lower stem woody, glabrate; branches 4-5 mm diam., smooth to striate, fistulose when dry, pubescent; younger stems to $3 \mathrm{~mm}$ diam., herbaceous, velutinous. Indumentum composed of hispid, simple, swollen-based hairs, c. $1.5 \mathrm{~mm}$ long, and shorter, 2-armed, erect hairs. Leaf petiole $2-2.5 \mathrm{~cm}$ long; blade broadly ovate-cordate, $9.5-14.2$ by $5.4-9 \mathrm{~cm}$, base cordate, apex apiculate to shortly caudate, adaxially castaneous, velutinous, abaxially \pm densely tawny-fulvous velutinous; venation with 3 basal pairs and 2 distal pairs of secondary veins. Inflorescence thyrsiform: a congested compound raceme, 40-51 cm long; lower bracts foliaceous, petiolate, petiole terete, (9-)15-25 mm long, blade ovate-cordate, 5.4-8.2 by $3.4-4.4 \mathrm{~cm}$; upper bracts diminishing in size, petiole $1-4 \mathrm{~mm}$ long, blade ovate to elliptic-fusiform, $4-7$ by $2-5 \mathrm{~mm}$; uppermost bracts sessile, subulate-lanceolate, $1-2$ $\mathrm{mm}$ long; pedicels filiform, $\leq 1 \mathrm{~mm}$ long; bracteoles 3 . Flower buds broadly ellipsoid, apex rounded. Sepals c. $1 \mathrm{~mm}$ long, outer 3 lanceolate to narrowly ovate, inner 2 linear to narrowly oblong, bases truncate, margins entire, apex obtuse to acute and slightly cucullate, outside densely velutinous, inside apex pilose-velutinous, otherwise glabrous. Corolla yellow, tube c. $1 \mathrm{~mm}$ long, limb 3(-4) mm diam., lobes broadly ovate to obovate, c. 1 by $1 \mathrm{~mm}$, apex obtuse to acute, outside velutinous, inside glabrous. Stamens c. $1 \mathrm{~mm}$ long, just protruding from corolla tube; filaments pilose basally, glabrous above; anthers broadly ellipsoid, extrorse, white; pollen 3-colpate, oblate spheroidal, c. 9 by $10-12 \mu \mathrm{m}$, surface finely granulate, pilate multiangulate within the colpi. Pistil c. $1.5 \mathrm{~mm}$ long, equal in length to calyx, just reaching mouth of corolla tube; ovary broadly ovoid, pale tan, glabrous; ovules 5; style absent; stigma sessile, biglobose, green drying to black. Fruiting calyx, utricle and seeds not seen.

Etymology - The specific epithet (from the Greek phalanthos 'bald in front' + petala) refers to the glabrous inner surface of the lobes of the deeply divided corolla.

Distribution - Known from the type locality in the Tenasserim Hills of Kanchanaburi province, southwestern Thailand, and in adjacent south-eastern Myanmar.

Habitat - Disturbed forest on limestone between 150-450 m elevation.

Note - Five-ovulate ovaries are extraordinary in the Convolvulaceae, where 2- or 4-ovulate ovaries are typical. Other ovule numbers are known to occur in isolated individuals, species, or groups of species (e.g. Ipomoea sect. Pharbitis) in genera otherwise having 2- or 4-ovulate ovaries. All flowers that I dissected from the type collection were found to have 5-ovulate ovaries. While it may be characteristic for this species, it is also possible that the plant from which the type was collected is aberrant in this character. Additional collections are needed to confirm that 5-ovulate ovaries are found in all individuals of $C$. phalanthopetalum.

Specimens examined:

Abdul Khalil s.n. (CAL), Myanmar, Southern Shan States, Indi, anno 1898; R.W. MacGregor 1800 (E), ibid., Keng Teng, elev. 1000 ft., Oct. 1884. 


\section{Cordisepalum thorelii (Gagnep.) Verdc. - Fig. 12 1-n; Map 1}

Cordisepalum thorelii (Gagnep.) Verdc. (1971) 138. - Cardiochlamys thorelii Gagnep. (1915a) 136.

- Type: Thorel 2625 (holo P, photo K; iso P, photo K), Laos.

Liana to 4-6(-8) $\mathrm{m}$ long; vegetative parts fulvous to ferruginous; older stems 5-8 mm diam., smooth to slightly striate, dark brownish black, \pm puberulous to subglabrous, pith solid; younger stems 1-2 mm diam., herbaceous, terete, tan to brownish, velutinous. Indumentum hairs 2 -armed; arms wavy, \pm appressed on axial parts, arms erect or ascending on laminar parts. Leaf petiole $17-43$ by $<1-2 \mathrm{~mm}, \pm$ velutinous; blade broadly ovate to attenuate-ovate, $8-11.5$ by $4.3-7.6 \mathrm{~cm}$, base subcordate, sinus broad and shallow, apex attenuate-acuminate to subcaudate, adaxially darker, \pm velutinous, abaxially greyish, tawny, or rufous, densely woolly; venation with 2 basal pairs and 1 or 2 distal pairs of secondary veins. Inflorescence lax, a simple or compound raceme $25-50 \mathrm{~cm}$ long; lower bracts petiolate, petioles (2-)5-13(-21) $\mathrm{mm}$ long, blades broadly ovate, $21-31$ by $13-24 \mathrm{~mm}$; upper bracts sessile, ovate, $12-19$ by $6-9 \mathrm{~mm}$, diminishing to small scales; pedicels filiform, $3-5 \mathrm{~mm}$, increasing to $8-10(-13) \mathrm{mm}$ in fruit; bracteoles $3,<1 \mathrm{~mm}$ long. Flowers fragrant; buds obovoid or ellipsoid, widest

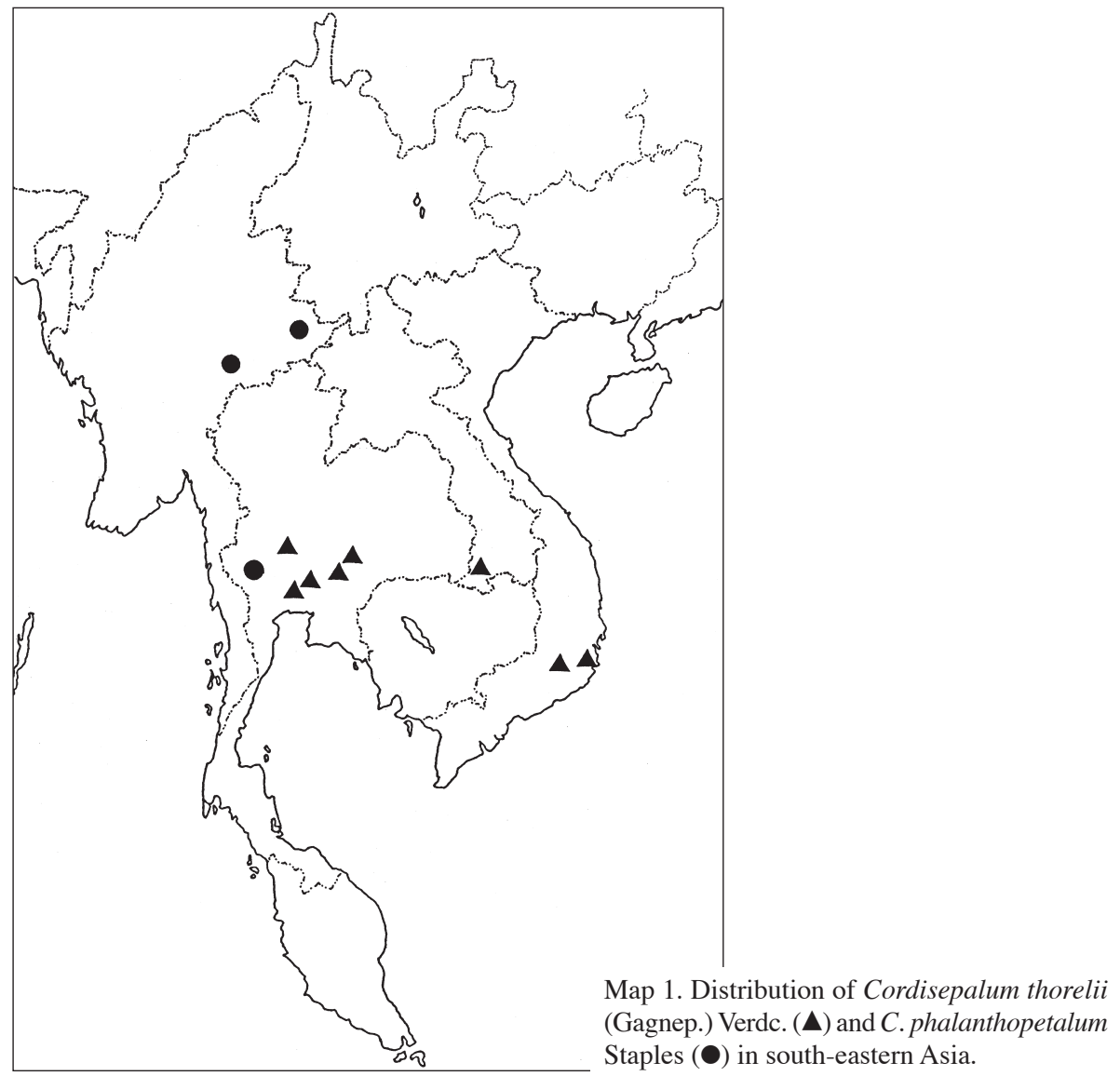


above calyx, apex rounded. Sepals naviculate, c. 2 by $<1 \mathrm{~mm}$; outer 3 obpandurate to narrowly ovate, inner 2 narrowly elliptic-oblong, bases truncate, margins entire, apex acute, outside densely velutinous, inside pilose apically, otherwise glabrous. Corolla cream to pale yellowish; tube 1-2 mm long, glabrous inside and out; limb (5-)7-11 mm diam.; lobes ovate, $3.5-5$ by $1.5-3 \mathrm{~mm}$, apex acute to acuminate, both sides densely velutinous-woolly. Stamens $<2 \mathrm{~mm}$ long, just protruding from corolla tube; filaments glabrous; anthers broadly ellipsoid, introrse, whitish; pollen 3-colpate, oblate spheroidal, c. 10 by $11-14 \mu \mathrm{m}$, surface psilate or finely granulate, with pilate multiangulate outgrowths within colpi. Pistil c. $2 \mathrm{~mm}$ long, just exceeding calyx, stigma protruding from corolla tube; ovary ovoid, glabrous; ovules 4; style short, terete; stigma biglobose. Fruiting calyx clasping utricle; sepals markedly unequal; outer 3 sepals broad ovatecordate to suborbicular, 21-28(-33) by 19-26(-28) mm, base cordate, lobes approaching or overlapping, margins entire, free, apex emarginate, mucronulate, third sepal folded back on itself along midvein (in dried material); inner 2 sepals linear-spathulate, falcate, $5-7$ by $<1-2 \mathrm{~mm}$; all sepals chartaceous, stramineous to tan, opaque, reticulate, both sides sparsely pilose. Utricle ellipsoid-fusiform, apiculate, $6-7$ by $3-4.5 \mathrm{~mm}$, borne on a columnar stalk c. $2 \mathrm{~mm}$ long, chartaceous, brownish, smooth or shallowly furrowed, tawny to rufous velutinous. Seed broadly ellipsoid, 4 by $3.5 \mathrm{~mm}$, dark reddish brown; hilum basal, c. $1 \mathrm{~mm}$ diameter.

Phenology - Flowering: February (1), April (1), October (1), November (4), December (5). Fruiting: December (1).

Distribution - Thailand, Laos, and Vietnam; probably also in Cambodia.

Habitat - Evergreen forests, mixed/disturbed and open hardwood forests, often in clearings or along the margins; seemingly always on limestone. From 25-1200 m elevation.

Vernacular names - Rahet khati dong (Thailand, Nakhon Ratchasima), re cai, ma coi (Vietnam, Moï dialect).

Notes - The vegetative morphology and fruiting sepals of $C$. thorelii approach those of Poranopsis sinensis. The two taxa are almost identical in the aspect of the infructescence and in the shape of the fruiting sepals. However, the sepal margins are free in $C$. thorelii and the utricle is borne on a slender stalk to $2 \mathrm{~mm}$ long. In flower, these plants are readily separable, with $C$. thorelii having a rotate, deeply 5-lobed corolla, whereas $P$. sinensis has a funnelform corolla.

Gagnepain (in Gagnepain \& Courchet, 1915a) described the corolla lobe aestivation in Cardiochlamys thorelii as quincuncial, which he assumed was the case in the two Madagascan taxa of Cardiochlamys as well, remarking that this character had been overlooked by Oliver (1883) and Hallier (1894) in their respective descriptions. My own examination of the flowers of $C$. thorelii shows that the aestivation is valvate: each corolla lobe has the margins first folded inward, and the infolded lobes are then apposed edge-to-edge in a valvate arrangement. There is also no twisting of the corolla lobes in bud. When the corolla is fully expanded the lobes overlap slightly at the margins and the arrangement at that stage appears to be quincuncial, which may be the source of Gagnepain's statement. Further investigation has shown that the corolla lobe aestivation in bud is also valvate in the Madagascan Cardiochlamys (Deroin, 2001).

Another inaccuracy to be corrected is that Gagnepain (in Gagnepain \& Courchet, 1915a) described and figured the ovary of C. thorelii as "breviter piloso-papillosum", 
which is not the case at the time of flowering. The ovary in every flower I dissected was exclusively glabrous, including flowers from the type collection. The utricles, however, are velutinous, and the indumentum first appears on the outer fruit wall during the development of the fruit. Possibly Gagnepain based his figure and description on recently fertilized gynoecia in the early stages of fruit development when the indumentum first appears.

\section{DINETUS - Fig. 8, 9}

Dinetus Sweet (1825) t. 127. - Type: Dinetus racemosus (Roxb.) Sweet. Dinetopsis Roberty (1952) 27. - Type: Dinetopsis grandiflora (Wall.) Roberty. Schillingia Verdc. ex Airy Shaw in Willis (1973) 1038, nomen. - Type: not designated.

Herbaceous, annual or perennial twiners, glabrous or sericeous. Roots fibrous (enlarged storage organs in $D$. duclouxii). Stems striate, nodes often pilose, otherwise subglabrous. Leaf petiole terete, sulcate adaxially, or compressed, pulvinus sometimes present; blade cordiform, entire or lobed, thinly chartaceous, venation pedate, secondary veins 2 or 3 basal pairs and 1, 2 (or 3) distal pairs, veins prominent, often alate abaxially. Inflorescences solitary or paired, axillary, bracteose, racemose or paniculate, anthesis proceeding acropetally; bracts foliaceous, petiolulate or sessile, amplexicaule, persisting; bracteoles 2 (or 3), minute scales (sepaloid in $D$. duclouxii), immediately below calyx. Flowers small to large, often fragrant; sepals 5 , free and quincuncial, or bases slightly connate, valvate, equal or unequal. Corolla funnelform or subsalverform, lobes contortuplicate in bud, glabrous except for tuft of hairs on apex of each interplica. Stamens 5, equal or unequal, included; lower filaments fused to corolla tube, base glabrous or pilose, free above; anthers hastate-sagittate or linear, introrse, longitudinally dehiscent prior to anthesis; pollen 3-colpate, nonspinose. Pistil included; disc annular, 5-lobulate, or absent; ovary unilocular; ovules 2, erect, basal; style, simple, often jointed above base; stigma ellipsoid, entire and emarginate or slightly apically bilobed. Fruiting calyx greatly accrescent, scarious, reflexed or loosely clasping utricle, with (5) 7, 9 (11) parallel, longitudinal veins at base, 3 reaching apex. Utricle chartaceous. Seed 1, ellipsoid to subglobose, often keeled, smooth, glabrous; hilum basal, recessed, semicircular. $\mathrm{n}=14$ (D. racemosus, Manitz, 1983 as Porana racemosa).

Dinetus is a genus of 8 species widely distributed in Asia. The genus name is derived from the Greek dinetos 'whirled round' in reference to the fruits that spin around as they fall. The diagnostic characters for recognizing it are: herbaceous habit; flower buds glabrous except for an apical tuft of hairs; an ellipsoidal, entire to emarginate stigma;

Fig. 8. Dinetus, 4 small-flowered species. - a-g: D. racemosus (Roxb.) Buch.-Ham. ex Sweet. a. Flowering stem habit; b. flower bud; c. flowering calyx (2 sepals removed) and gynoecium; d. corolla opened to show stamen attachment; e. utricle with \pm clasping calyx; f. utricle with spreading calyx; g. utricle eroded at base to expose seed. - h-l: D. truncatus (Kurz) Staples. h. Fruiting stem habit; i. utricle in side view; j. utricle base; k. utricle opened to show spongy layer; 1 . fruiting sepal. - m-r: D. malabaricus (C.B. Clarke) Staples. m. Flower bud; n. opened corolla to show stamen attachment; o. calyx (2 sepals removed) and gynoecium; p. fruiting calyx; q. fruiting calyx; r. fruiting calyx (sepals removed) and utricle. $-\mathrm{s}-\mathrm{v}$ : D. dinetoides (C.K. Schneid.) Staples. s. Corolla 


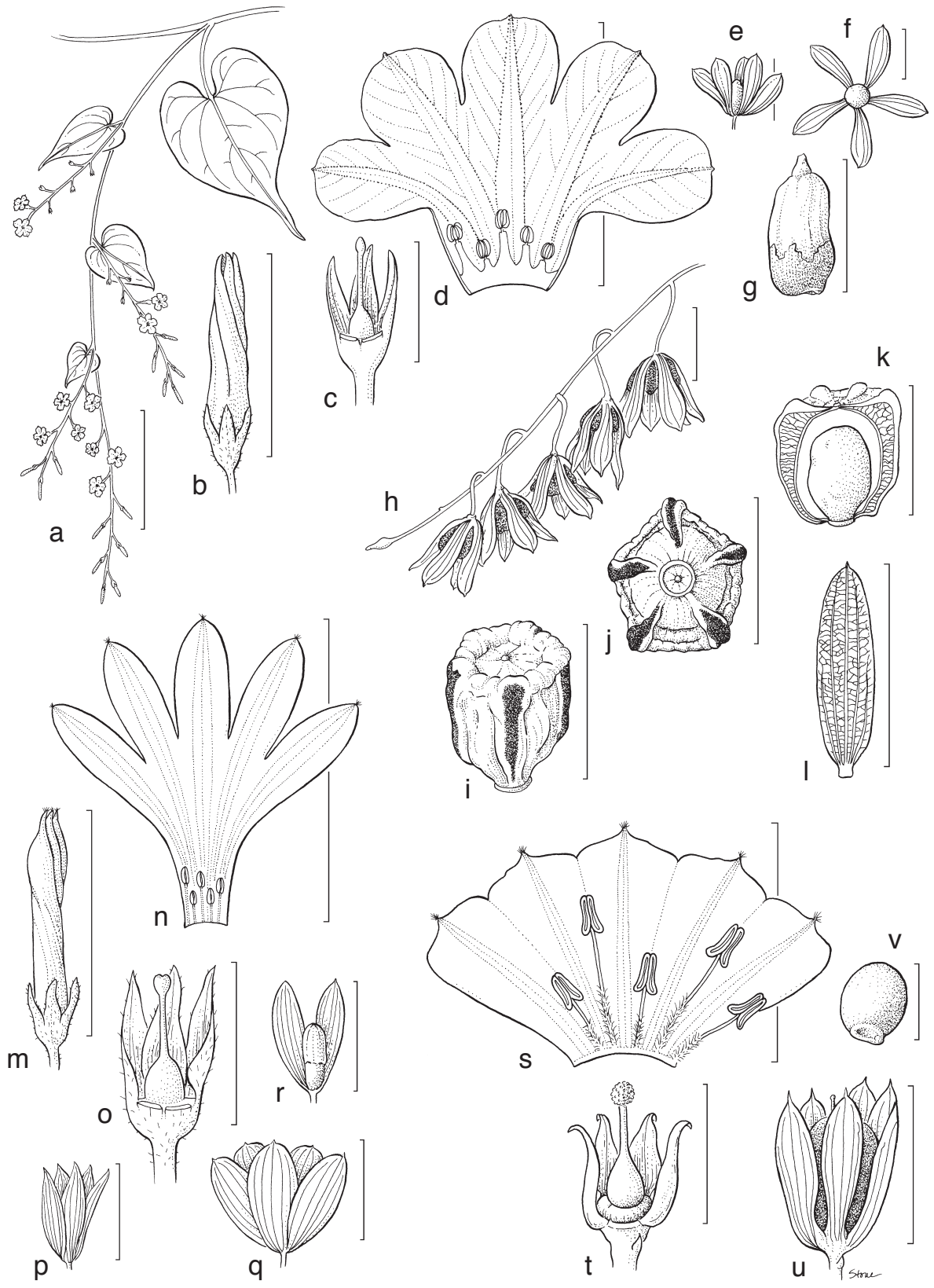

opened; t. flowering calyx (1 sepal removed) and gynoecium; u. fruiting calyx and utricle; v. seed (a: adapted from W.P. Fang 5592 and Henry 2595; b-d: Staples 131; e: Tsai 56660; f, g: Staples et al. 427; h-1: Staples et al. 425; h: redrawn from photo; m-o: H.S. (= Santapau) 2958; p, r: Santapau 9545; q: Stocks \& Law s.n.; s, t: Henry 9340; u, v: Henry 9340a). Scale bars: a = $5 \mathrm{~cm} ; \mathrm{b}, \mathrm{u}=8 \mathrm{~mm} ; \mathrm{c}, \mathrm{o}, \mathrm{v}=3 \mathrm{~mm} ; \mathrm{d}=9 \mathrm{~mm} ; \mathrm{e}, \mathrm{f}, \mathrm{m}, \mathrm{n}=1 \mathrm{~cm} ; \mathrm{g}=5 \mathrm{~mm} ; \mathrm{h}, 1=1.5 \mathrm{~cm} ; \mathrm{i}-\mathrm{k}=6 \mathrm{~mm}$; $\mathrm{p}, \mathrm{r}=2 \mathrm{~cm} ; \mathrm{q}=1.9 \mathrm{~cm} ; \mathrm{s}=7 \mathrm{~mm} ; \mathrm{t}=2 \mathrm{~mm}$. 

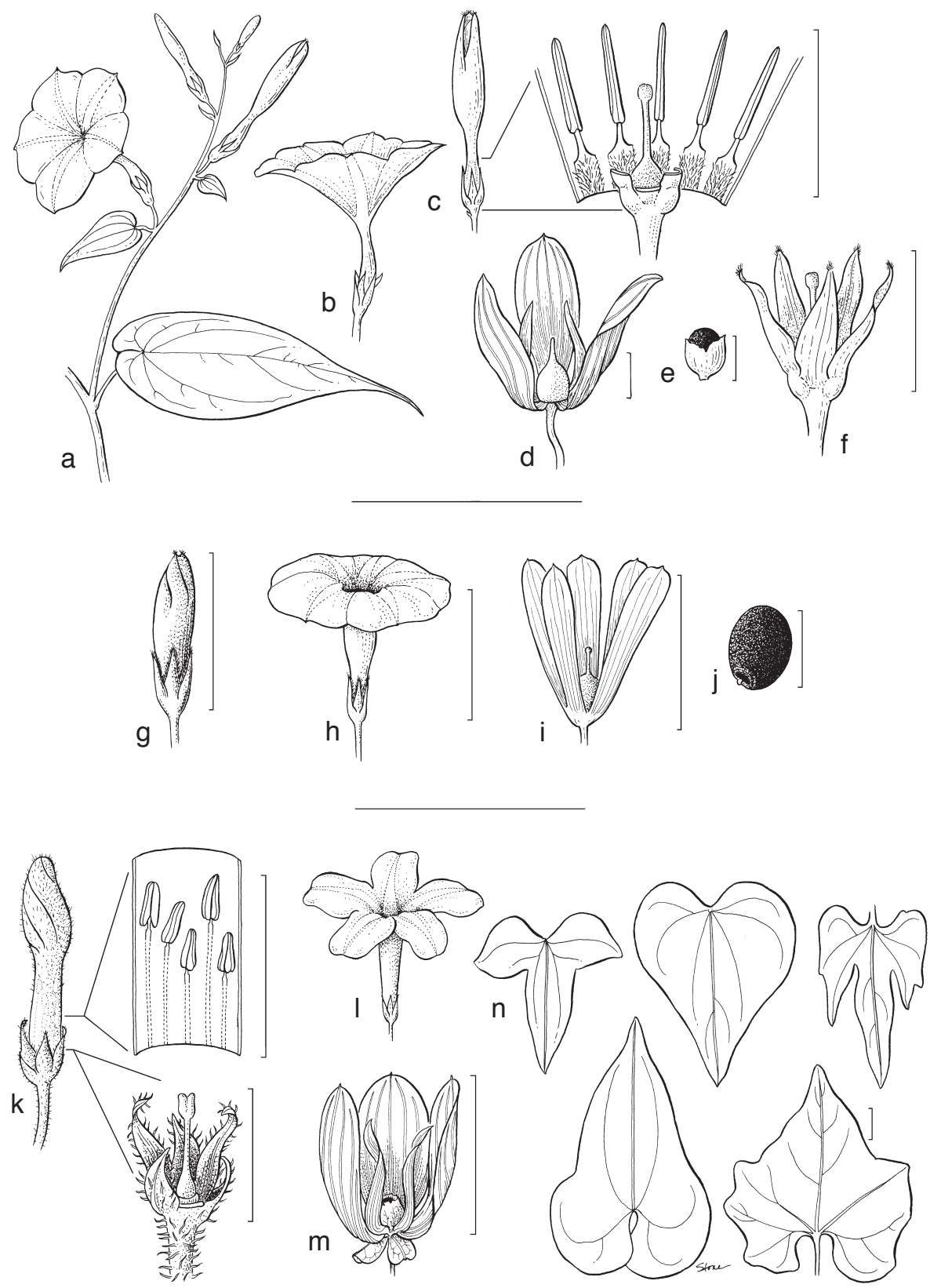

Fig. 9. Dinetus, 3 large-flowered species. - a-f: D. grandiflorus. a. Flowering stem habit; b. flower in side view; c. mature bud showing swollen tube base, and opened to show equal stamens, gynoecium; d. fruiting sepals and utricle; e. utricle broken to expose seed; f. flowering sepals. $-\mathrm{g}-\mathrm{j}$ : D. decorus. g. Flower bud; h. flower; i. fruiting calyx and utricle; j. seed. $-\mathrm{k}-\mathrm{n}$ : D. duclouxii. $\mathrm{k}$. Flower bud showing cylindrical tube with insets showing stamens and calyx ( 2 sepals removed), gynoecium, and 2 bracteoles; 1 . flower; $m$. fruiting calyx, enlarged bracteoles, and utricle; $n$. leaf 
fruiting sepals with multiple, parallel longitudinal veins; the calyx reflexed from the utricle at maturity, or fruit sepals strongly concave and enclosing the utricle.

Two informal species groups are clearly recognizable with a single species having intermediate characteristics. The 'Dinetus' group (Fig. 8) is recognizable by its small flowers ( $<1 \mathrm{~cm}$ long) with white corollas and by the fruiting calyces with 5 flat, equally accrescent sepals that are reflexed at maturity. Additional characters distinguishing the 'Dinetus' group include the presence of stellate hairs (in some species), flowering sepals equal, slightly connate at the base and valvate in aestivation, sagittate-hastate anthers with diverging bases, and usually 5 or 7 veins at the base of the fruiting sepals.

The 5 species comprising the 'Dinetus' species group are separable inter se primarily by characters of the fruiting calyx and utricle. Variation in the sepal shape, size, coloration, utricle shape, degree of separation between the pericarp and the single seed, and the coloration and pubescence of the utricle are taxonomically informative. Floral characters are useful only to distinguish $D$. dinetoides from the other members of the group. The flowers of $D$. rhombicarpus are unknown and those of $D$. truncatus insufficiently known. It is likely that some of the flowering material herein assigned to Dinetus racemosus is misidentified, and actually represents the other three species, D. malabaricus, D. rhombicarpus, and D. truncatus. Further study is needed, using plants raised in cultivation from seed of known identity, to establish what, if any, floral morphological differences exist between these four species.

The second species group, consisting of $D$. duclouxii and $D$. grandiflorus, has larger flowers (2.2-4 cm long) with corollas of various colours, but only rarely white. The fruiting sepals are unequally enlarged, concave, and loosely enclose the utricle. The flowering sepals are equal or unequal, free and quincuncial in aestivation, the anthers linear, and the fruiting sepals with 7, 9 or 11 veins at the base. I refer to this pair informally as the 'Dinetopsis' group (Fig. 9).

The intermediate species, Dinetus decorus, has a suite of characters that bridges the gap between the two groups, including: a rose pink corolla $1.7-2.3 \mathrm{~cm}$ long; flowering sepals equal, basally connate, and valvate in aestivation; anthers hastate with diverging bases; and fruit sepals that are flat, equally enlarged, with 5 veins at the base, but which loosely enclose the utricle. Purely for convenience I have decided to include this species in the 'Dinetopsis' group, because the easily visible morphological characters (large, coloured corolla, and enclosing fruiting sepals) are like those of the 'Dinetopsis' group. Pollen morphology also supports this placement, because the grains of all 3 species assigned to the 'Dinetopsis' group are oblate spheroidal and more coarsely granular on the surface than those of the 'Dinetus' group, which are finely psilate but not granular. Further study of the infrageneric relationships is needed.

The name Schillingia was published by Airy Shaw (in Willis, 1973) after discussions with Bernard Verdcourt regarding the identity of Schilling 612 (Verdcourt, pers.

blade diversity (a, b: drawn from colour slide; c, f: De Haas 2053; d, e: J.D. Hooker s.n.; g: Ten 173; h: redrawn from Fang \& Huang 1979b: t. 8; i, j: Kingdon-Ward 7741; k, 1: Handel-Mazzetti 7041; m: Henry 9229d; n: top row-left, from Hsieh 41660; middle, anonymous 8714; right, anonymous 5230; bottom row-left, Tsiang 1242; right, Handel-Mazzetti 7041). Scale bars: a-c = 7 mm; d, e, n $=1 \mathrm{~cm} ; \mathrm{f}=5 \mathrm{~mm} ; \mathrm{g}=8 \mathrm{~mm} ; \mathrm{h}=1.7 \mathrm{~cm} ; \mathrm{i}=1.8 \mathrm{~cm} ; \mathrm{j}, \mathrm{k}$ (calyx, gynoecium, bracteoles) $=4 \mathrm{~mm}$; $\mathrm{k}=9 \mathrm{~mm}$ (stamens); $1, \mathrm{~m}=2 \mathrm{~cm}$. 
comm. 1984). At the time of the discussions, Verdcourt was puzzled by the identity of this collection, and thought it might represent an undescribed genus of the Convolvulaceae. Verdcourt later realized that the plant collected by Schilling was conspecific with Ipomoea cuspidata D.Don, and correctly identified that name as a synonym of Porana grandiflora (Verdcourt, 1970). Airy Shaw (in Willis, 1973), unaware that the plant had been identified as Porana grandiflora, went on to use the name Schillingia, credited to Verdcourt. No specific epithet was published or combined in it.

\section{KEY TO THE SPECIES}

1a. Corolla 1.5-4 cm long, rose pink, lavender, blue, or violet (rarely white in $D . d u$ clouxii); fruiting sepals \pm unequal, loosely clasping the utricle . . . . . . . 2

b. Corolla $<1 \mathrm{~cm}$ long, white; fruiting sepals (sub)equal, reflexed at maturity . . 4 2a. Plants \pm viscid glandular; bracteoles 3 , sepaloid . . . . . . . 5. D. duclouxii

b. Plants pubescent or glabrous, never viscid; bracteoles 2 , minute, scale-like . . 3

3a. Corolla funnelform, $1.7-2.3 \mathrm{~cm}$ long, tube tapering from the base upwards; fruiting

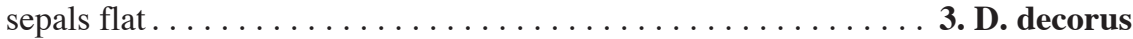

b. Corolla subsalverform, $3-4.5 \mathrm{~cm}$ long, tube narrow with a basal swelling; fruiting

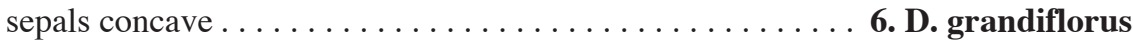

4a. Leaves bifacially hairy; corolla campanulate . . . . . . . 4. D. dinetoides

b. Leaves subglabrous adaxially; corolla funnelform . . . . . . . . . . 5

5a. Fruiting sepals linear-oblong to narrowly obovoid-spatulate $\ldots \ldots \ldots \ldots \ldots$

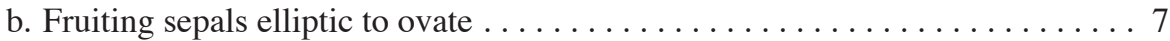

6a. Utricle ellipsoidal and apiculate $\ldots \ldots \ldots \ldots \ldots \ldots \ldots \ldots$. D. racemosus

b. Utricle broadly obovoid, truncate or depressed at the apex ... 10. D. truncatus

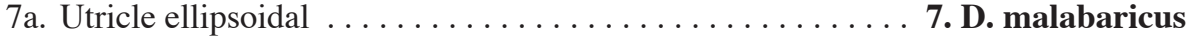

b. Utricle broadly rhomboidal . . . . . . . . . . . 9. D. rhombicarpus

\section{Dinetus decorus (W.W. Sm.) Staples - Fig. 9g-j; Map 2}

Dinetus decorus (W.W. Sm.) Staples (1993) 199. - Porana decora W.W. Sm. (1914) 197. - Type: Maire 64 (holo E; iso BM), China.

Porana mairei Gagnep. in Gagnep. \& Courchet (1915a) 154, excl. note about fruit. - Type: Maire s.n. (lectotype (here designated) P; isolectotypes A, E, G, L, P), China.

Porana microsepala Hand.-Mazz. (1921) 229. - Type: Pater S. Ten 1980 (lectotype (here designated) $\mathrm{C}$; isolectotype WU), China.

Porana macrocephala Hand.-Mazz. ex Erdtman (1952) 128, nomen, sphalm. 'Porana microsepala' Hand.-Mazz. based on Handel-Mazzetti 4929.

Porana mairei Gagnep. var. holosericea C.Y. Wu in Fang \& Huang (1979b) 163. - Type: SichuanLiangjang Team 5830 (holo KUN; iso PE), China.

Perennial twiners or prostrate, to $2 \mathrm{~m}$ long, branches pendulous, vegetative parts silverywhite. Stem terete, 3-5 mm diam., stramineous to deep brown or purplish, \pm puberulent, older stems glabrate. Indumentum greyish white, axial parts \pm velutinous, laminar parts sericeous, hairs 2-armed. Leaf petiole $2.5-8.4 \mathrm{~cm}$ long; blade broadly ovate-cordate, $8-14$ by $4.8-10 \mathrm{~cm}$, base shallowly to deeply cordate, sinus broad, apex attenuate or acute, cuspidate, texture chartaceous, adaxially olivaceous, glabrous to sparsely and minutely strigose, abaxially tawny and subglabrous to greyish white and \pm shining 
sericeous. Inflorescence pendulous, 21-33 cm long; lower bracts petiolate, petioles 7-12 mm long, blades cordate-ovate, $4.1-6$ by $1.7-3 \mathrm{~cm}$, base with deep, narrow sinus, apically attenuate; upper bracts sessile, lanceolate-filiform, $1-4$ by $0.8-1.6 \mathrm{~cm}$, base amplexicaule; bracts mostly deciduous in fruit; pedicels filiform, $8-12 \mathrm{~mm}$ long; bracteoles 2, immediately below calyx, filiform, to $3 \mathrm{~mm}$ long, deciduous or persisting but not enlarging in fruit. Flowers showy; buds clavate to slenderly obovoid, 17-24 mm long. Sepals equal, often divergent, lanceolate to narrowly ovate or subulate, 2-3 by $<1 \mathrm{~mm}$, truncate basally, margins entire, often slightly revolute, apex acute to attenuate, abaxially shining golden sericeous, along margins (or entire surface). Corolla slenderly funnelform to subsalverform, $1.7-2.3$ by $1.5-1.8 \mathrm{~cm}$, diaphanous, outside rose-pink or purplish to white, inside white, tube gradually widening, limb flaring abruptly, subentire, glabrous except for small golden hair tufts at apices of interplicae and a few scattered hairs on tube. Stamens unequal, biseriate; filaments 4-7 mm long, glabrous; anthers hastate, c. $1 \mathrm{~mm}$ long, yellowish white; pollen 3-colpate, oblate spheroidal, c. 10 by $12-14 \mu \mathrm{m}$, surface granulate. Pistil c. twice as long as calyx; disc absent; ovary ovoid-conical, c. $1 \mathrm{~mm}$ long; style 2-3 mm long, golden-tan; stigma broadly ellipsoid-oblong, emarginate to slightly bilobed apically, greyish tan. Fruiting calyx loosely clasping to slightly spreading from the utricle; sepals (sub)equal, oblong to elliptic-oblong to subspatulate, flat, 3 outer $23-31$ by $6-8 \mathrm{~mm}, 2$ inner $15-30$ by 4-7 mm, texture stiffly chartaceous, tan to brown to purplish brown, glabrous. Utricle obovoid, apiculate, $6-7$ by $4-5 \mathrm{~mm}$, chartaceous, tan to deep reddish or purple-brown, finely wrinkled, glabrous. Seed globose to broadly ellipsoid, $4-5$ by $4 \mathrm{~mm}$, reddish tan, smooth, glabrous.

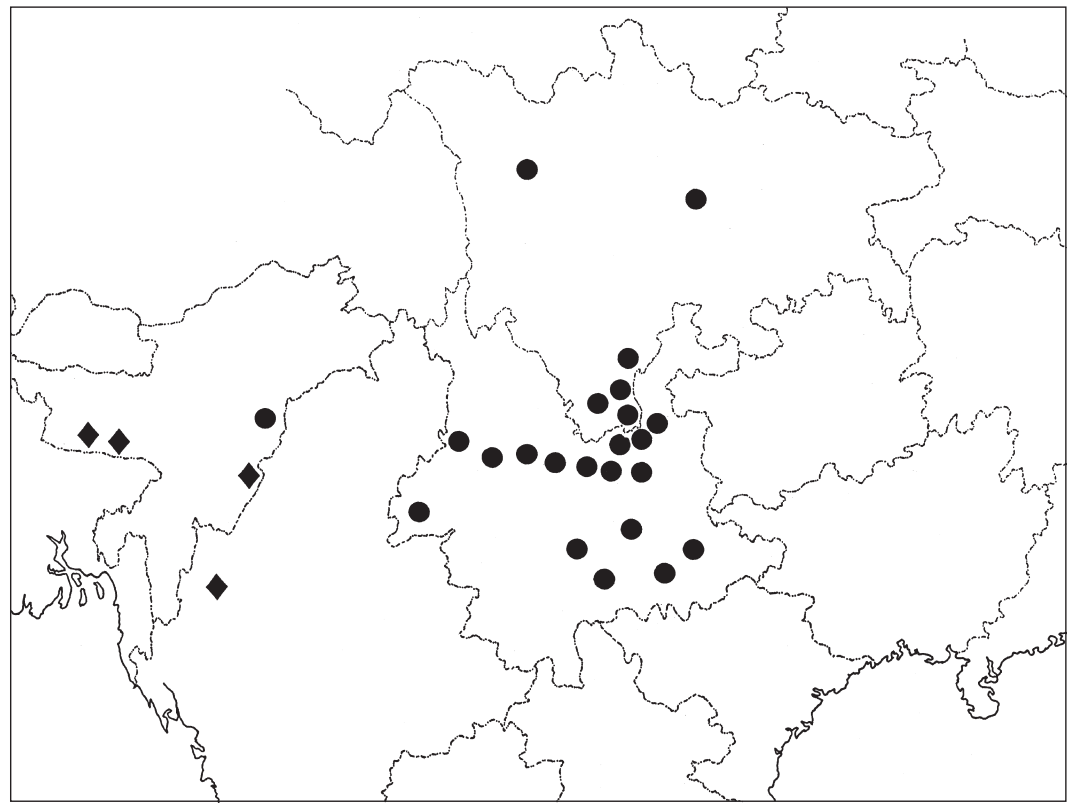

Map 2. Distribution of Dinetus decorus (W.W. Sm.) Staples (•) and D. rhombicarpus Staples ( in the eastern Indian subcontinent and western China. 
Distribution - China (Yunnan, Sichuan) and north-eastern India (Nagaland) surely also in intervening northern Myanmar.

Habitat - Forest, often in river valleys and on steep, often rocky slopes, at 13003500 m elevation.

Phenology -Flowering: June (5), July (12), August (10), September (2). Fruiting: October (4), November (3), December (1).

Vernacular name - Bai teng (China).

Typification - Gagnepain \& Courchet (1915a) based P. mairei on a series of syntypes, including Wilson $4186 a$, which is actually a fruiting collection of $D$. duclouxii. Their species concept is here amended to exclude the fruiting characters based on Wilson 4186a.

Note - The diagnostic characters for $D$. decorus are: a medium-sized slenderly funnelform to subsalverform corolla which is pink or rose; unequal stamens with hastatesagittate, 1-2 mm long anthers; filiform bracteoles, which are not accrescent in fruit; (sub)equal, flat, stiffly chartaceous fruiting sepals. In addition, the white under surface of the leaves is reported by collectors to be a good field character for distinguishing the species. This last character is the source of its common name in Chinese, bai teng - white cane or white vine.

4. Dinetus dinetoides (C.K. Schneid.) Staples - Fig. 8s-v; Map 3

Dinetus dinetoides (C.K. Schneid.) Staples (1993) 199. - Porana dinetoides C.K. Schneid. (1916) 360. - Type: A. Henry 9340 (holo A; iso E, K, MO, NY, US), China.

Porana megathyrsa C.Y. Wu in Wu \& Li (1965) 101, t. 18. - Type: G.S. Sin 1044 (holo KUN; iso IBSC, KUN, PE), China.

Porana brevisepala C.Y. Wu \& S.H. Huang in Fang \& Huang (1979a) 630, t. 179, f. 4, 5. - Type: C.A. Wu 9775 (holo KUN; iso KUN), China.

Porana dinetoides C.K. Schneid. var. mienningensis S.H. Huang in Fang \& Huang (1979b) 163. - Type: T.S. Ying 4342 (holo KUN, not found; iso KUN), China.

Perennial herbaceous climber to $3 \mathrm{~m}$ long. Stem twining, terete, faintly striate, minutely verruculose, 2-3 mm diam., stramineous to reddish brown, tomentose-pilose, glabrate with age, pith solid. Indumentum yellowish, tomentose; axial parts with mixture of longer, erect simple hairs and shorter, \pm appressed, 2-armed hairs; laminar parts hairs mostly 2 -armed. Leaf petiole $23-70$ by $1-3 \mathrm{~mm}$, pulvinate; blade cordate to broadly ovate-cordate, $5.8-11$ by $4.3-8.7 \mathrm{~cm}$, base deeply cordate, apex caudate or acuminate and mucronate, adaxially darker, yellowish green, smooth and \pm sericeous, abaxially tomentose, more so along veins. Inflorescence $18-35 \mathrm{~cm}$ long; lower bracts petiolate, petiole $1.2-3.5 \mathrm{~cm}$ long, blades cordate, $4.5-8$ by $3.2-4.6 \mathrm{~cm}$, persisting; upper bracts becoming sessile, diminishing to 1-3 mm long, caducous; pedicels filiform, 4-5 mm; bracteoles 2, minute scales, immediately subtending calyx. Flower buds ellipsoidfusiform, obtuse. Calyx urceolate in bud, becoming campanulate as corolla enlarges; sepals 5, equal, triangular to narrowly ovate, becoming cymbiform at anthesis, 1-2 by $<1 \mathrm{~mm}$, herbaceous, basally connate, margins glabrous or reddish sericeous, apex attenuate-apiculate, recurved. Corolla campanulate, flaring from base, entire, 4-7 by 4-6 mm, membranous, white, outside glabrous except for apical hair tuft on each interplica, inside glabrous. Stamens unequal, 2 (or 3) just reaching corolla throat, 2 (or 3 ) 


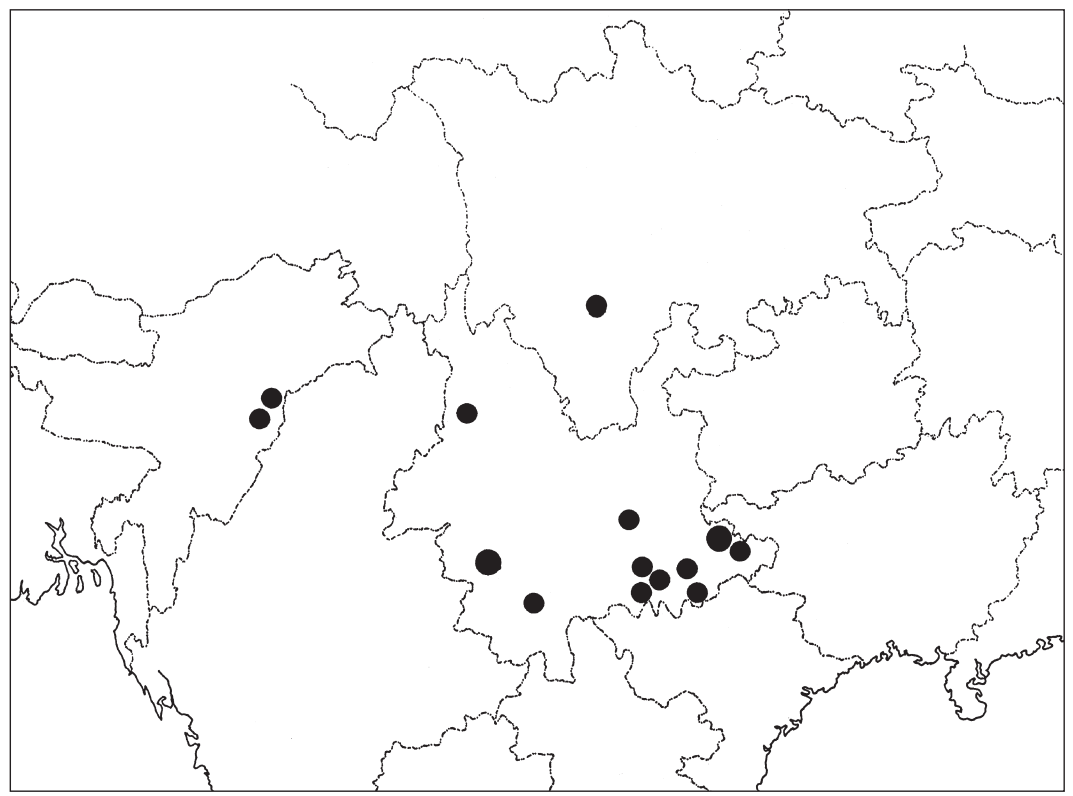

Map 3. Distribution of Dinetus dinetoides (C.K. Schneid.) Staples in the eastern Indian subcontinent and western China.

included; filaments pilose basally, glabrous above; anthers c. $1 \mathrm{~mm}$ long, white; pollen 3 -colpate, oblate or prolate spheroidal, $12-15$ by $11-16 \mu \mathrm{m}$, surface psilate. Pistil just exceeding calyx; disc annular; ovary conical, $<1 \mathrm{~mm}$ tall; style 1-1.5 mm long; stigma ellipsoid-globose, c. $1 \mathrm{~mm}$ diam., emarginate. Fruiting calyx clasping utricle (reflexed at maturity?); sepals subequal, spathulate to linear-oblong, mucronate, $6-10$ by $1.5-3$ $\mathrm{mm}$, chartaceous, glabrous or ciliate; 3 nerves extending to apex. Utricle ellipsoid-ovoid, rarely obovoid, apiculate, $6-8$ by $4-5 \mathrm{~mm}$, chartaceous, tan to brownish, glabrous. Seed ellipsoid, 3 by $2 \mathrm{~mm}$, smooth, brownish, glabrous.

Distribution - China (Sichuan, Yunnan), India (Nagaland), and surely in N Myanmar.

Habitat - Forests and grassy slopes in mountainous areas ranging from 12002200 m elevation.

Phenology - Flowering: July (2), August (4), September (4), October (3). Fruiting: September (2), November (1).

Typification - A comment on the type collections of Porana dinetoides is warranted. Based on the fragmentary label information gleaned from duplicates of Henry's 9340, $9340 a, 9340 b$, and $9340 c$, it seems certain that he mixed under one collection number plants gathered from several localities spanning a period of at least three months; subsequently he tried to separate the material into discrete units. The type gathering, 9340, is in flower, and bears the locality "Laochen mts, 14 Sept." (US) and "E mts." (E). Number 9340a is in fruit and is dated "8 Nov." (US). Sheets numbered $9340 b$ are in flower, have no date, and the elevations range from 1000-2000 ft (NY) to $5000 \mathrm{ft}$ (A) to $5500 \mathrm{ft}(\mathrm{K})$. All of these collections are labelled "Mengtze." Number $9340 \mathrm{~b}$ 
(CAL) indicates "Szemao" as place of collection, and 9340c (K) does likewise, adding "W mts., $5000 \mathrm{ft}$ "; both these specimens are in flower.

Note - Dinetus dinetoides is distinct from the other members of the genus by virtue of its shortly gamosepalous calyx, densely pilose filaments, and nearly exserted anthers. It may be separated from the similar D. racemosus by its hairy leaves, obtuse flower buds, densely pilose filament bases, subexserted stamens, and floral disc.

\section{Dinetus duclouxii (Gagnep. \& Courchet) Staples - Fig. 9k-n; Map 4}

Dinetus duclouxii (Gagnep. \& Courchet) Staples (1993) 199. - Porana duclouxii Gagnep. \& Courchet (1915a) 153. - Type: Ducloux 5459 (lecto P), China.

Ipomoea \#26 F. B. Forbes \& Hemsl. (1890) 163, nomen, based on Faber 1199.

Porana triserialis C. K. Schneid. (1916) 356. - Type: A. Henry 3220 (holo A; iso A, BM, E, F, K, MO, US), China.

Porana triserialis C.K. Schneid. var. lasia C.K. Schneid. (1916) 362. - Porana duclouxii Gagnep. \& Courchet var. lasia (C.K. Schneid.) Hand.-Mazz. (1936) 809. - Type: A. Henry 9229c, p.p. (holo A), China.

Porana lutingensis Lingelsh. in Pax (1922) 471. - Type: A. Limpricht 1628 (holo not found; photo and fragment A, ex WRSL), China.

Porana lobata C. Y. Wu in Wu \& Li (1965) 105, t. 34, f. 3. - Type: F.T. Wang 22608 (holo KUN; iso NAS, PE), China.

Perennial twiner, branches often pendant, 1-7 m long, often viscid glandulose; roots enlarged, conical, $3-6.8$ by $4.2-5.1 \mathrm{~cm}$, yellowish when fresh; finer roots fibrous. Stem twining, terete, faintly striate or smooth, sometimes minutely verruculose, stramineous to reddish purple, glabrous or \pm viscid. Indumentum yellowish to reddish, a mixture of simple trichomes and multicellular, glandular trichomes, with or without a swollen apical cell. Leaf petiole $2.2-7 \mathrm{~cm}$ long; blade variable in shape, broadly ovate to cordate, hastate, or sagittate in outline, $6.4-11.5$ by $4.3-9.6 \mathrm{~cm}$, base deeply cordate, sagittate, or hastate with broadly rounded lobes, margins entire, undulate, or palmately 3-lobed or cleft, or \pm irregularly incised, apex attenuate, mucronulate, texture chartaceous, adaxially brownish, glabrous to \pm viscid puberulent, abaxially greyish, glabrous to densely viscid tomentose; lower order veins covered with minute pustules or vesicles. Inflorescence $8-17(-40) \mathrm{cm}$ long, sometimes with a small raceme arising from lower axil; lower bracts petiolate, petiole 3-18 mm long, blade ovate, $1.9-4.4$ by $1-2.7 \mathrm{~cm}$, base shallowly cordate, apex attenuate, deciduous; upper bracts diminishing in size, becoming sessile, linear-subulate, $4-8$ by $\leq 1 \mathrm{~mm}$, deciduous; pedicels filiform, $6-11$ $\mathrm{mm}$; bracteoles 3 , unequal, immediately subtending calyx, ovate, c. $1 \mathrm{~mm}$ long, to lanceolate, $3-5$ by $\leq 1 \mathrm{~mm}$, flat or undulate, in fruit enlarging and becoming reflexed along pedicel, circular, ovate or obovate, unequal, $3-11(-14)$ by $1-5(-8) \mathrm{mm}$, apex often inequilateral. Flowers showy, fragrant; buds slenderly clavate to spatulate, apex acute to obtuse. Sepals unequal, triangular-ovate to lanceolate to linear-subulate, outer 3 larger, $3-8$ by $1-2 \mathrm{~mm}$, inner 2 smaller, $1.5-4$ by $0.5-1 \mathrm{~mm}$, base truncate, margins entire, flat, undulate, or crinkled distally, apex acute to acuminate, texture herbaceous, smooth to faintly striate, glabrous or viscid pubescent; venation not visible. Corolla salverform to narrowly funnelform, $2.2-3.5$ by $1.7-3.4 \mathrm{~cm}$, diaphanous, tube narrow, yellowish inside, limb flaring, white to pale yellow, lavender, blue, reddish, or violet, deeply 5-parted, lobes obtuse to rounded, mucronate. Stamens unequal, 5-10 mm long, 
usually triseriate, yellowish white; filaments (3-)5-8 mm long, basal $2 \mathrm{~mm}$ villous, otherwise glabrous; anthers linear, 1.5-2 mm, yellowish white; pollen 3-colpate, oblate spheroidal to obtusely triangular, c. 10 by $12-14 \mu \mathrm{m}$, surface psilate. Pistil shorter than calyx, 4(-5) mm long; disc annular, slightly 5-lobed, or absent; ovary ovoid, c. $1 \mathrm{~mm}$ tall; style c. $2 \mathrm{~mm}$ long, white; stigma oblong to narrowly obovoid, c. $0.5 \mathrm{~mm}$ long, emarginate to bilobed, sometimes inequilateral, green when fresh, pale grey when dry. Fruiting calyx clasping utricle, sepals unequal, bases encircling utricle, distally flattened and flaring; outer 3 sepals narrowly ovate to elliptic, $1.9-3.7$ by $0.7-1.3 \mathrm{~cm}$, inner 2 linear-lanceolate to narrowly elliptic, $1.5-2$ by $0.3-0.9 \mathrm{~cm}$, margins entire, sometimes undulate or ciliolate, apex acuminate, acute, obtuse or rounded, apiculate, texture stiffly chartaceous, tan to purple-brown when dried, glabrous or \pm viscid. Utricle globose to broadly ellipsoid, $5-8$ by $5-7 \mathrm{~mm}$, apiculate by persistent $1-2 \mathrm{~mm}$ long style, thinly chartaceous to membranous, sometimes hyaline, smooth to faintly striate, pale yellowish tan to dark chestnut brown, glabrous. Seed (sub)globose, $5-6$ by $4-5 \mathrm{~mm}$, reddish brown to black-brown, scurfy yellowish at first, later smooth, glabrous.

Distribution - China (Hubei, Sichuan, Yunnan).

Habitat - Roadsides, margins of fields, grassy areas, thickets, stream banks, in scrub, often in rocky or stony situations and several times collected on calcareous or limestone substrates at (120-)900-2000(-4000) m elevation.

Phenology - Flowering: February (3), May (6), June (3), July (5), August (14), September (16), October (8), November (1), December (1). Fruiting: September (5), October (8), November (3).

Notes - The following unique characters distinguish $D$. duclouxii: markedly unequal, glabrous or glandular flowering sepals; a salverform corolla with a slender tube;

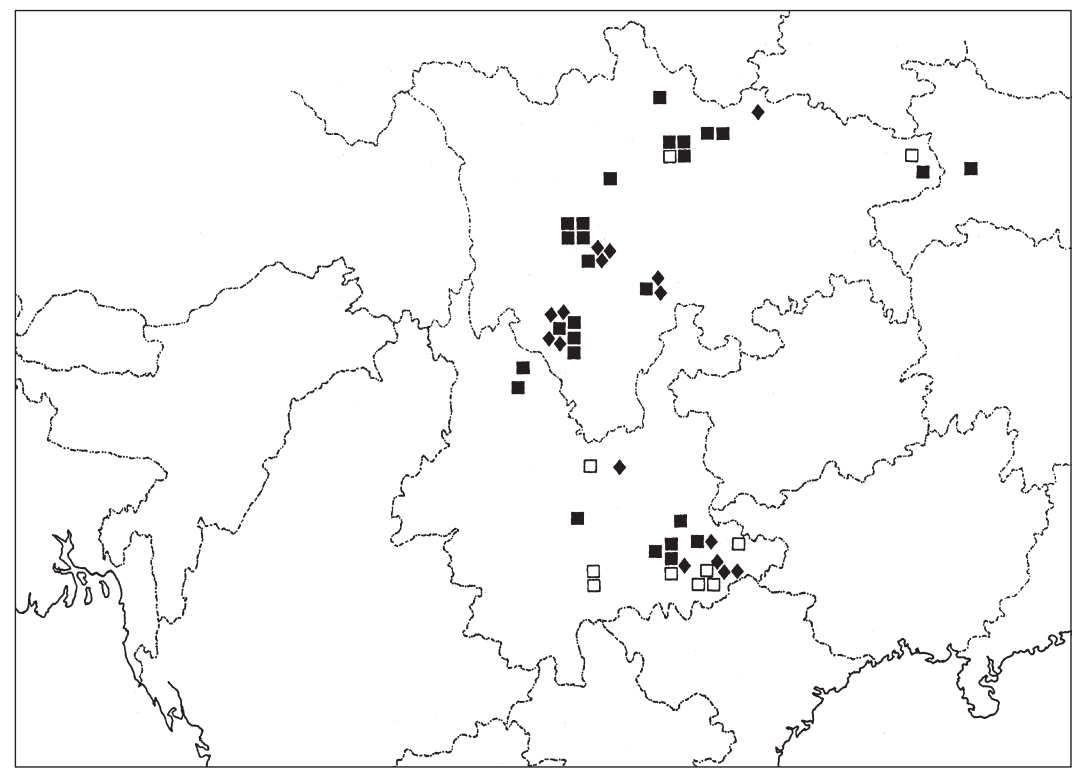

Map 4. Distribution of Dinetus duclouxii (Gagnep. \& Courchet) Staples in western China: dark flowered plants ( $\square$ ); light flowered plants ( $\square$ ); fruiting plants 
unequal stamens inserted in ( 2 or) 3 series below the middle of the tube; 3 prominent bracteoles, which become accrescent and reflexed in fruit, and are borne immediately below the calyx. The presence of viscid, multicellular glandular trichomes on the vegetative parts is also unique to this species, though some individuals have so few as to seem glabrous.

Ducloux 5459 is the only collection cited by Gagnepain \& Courchet that agrees with the protologue in being glabrous and having white corollas; it is here chosen as lectotype. The other cited syntypes are wholly or partly glandular viscid hairy, or have corollas that are not white, which seems to have been overlooked in drafting the protologue.

Dinetus duclouxii is variable in leaf shape (Fig. 9n), corolla colour, relative stamen length, and density of glandular indumentum. This variation has provided the foundation for taxonomic overdescription, with several distinctive phenotypes having received taxonomic recognition. As with numerous other species in the Convolvulaceae, these character states are not taxonomically reliable. The protologue of Porana duclouxii, for example, defines the taxon as glabrous and white-flowered. However, individuals having this combination of character states are a minority within the species as a whole. Most specimens in my sample have glandular trichomes as well as simple trichomes, and dark-coloured corollas outnumber white or pale yellow corollas. The taxonomic concept adopted here recognizes considerable variation as a single polymorphic species.

My examination of all available material demonstrates that the density of glandular hairs varies continuously across populations and it is the extreme ends of the continuum that have been granted taxonomic recognition. I have been unable to demonstrate any correlation between the presence/absence of glandular indumentum and geographic distribution. Likewise, habitat preference, altitudinal range, and season of collection have no apparent correlation with the indumentum character. While recent workers have maintained varietal status for the glandulose plants, I do not find any basis for doing so.

Similarly, the relative lengths of the 5 stamens vary, and three patterns of stamen length have been observed: stamens of 3 lengths (triseriate) and two biseriate patterns (3 long, 2 short) and (2 long, 3 short). These relative lengths are taxonomically uninformative, inter se, but the unequal stamens immediately separate $D$. duclouxii from D. grandiflora, which has equal stamens, 5-6 $\mathrm{mm}$ long.

Leaf shape varies greatly in this species and Porana lobata C.Y. Wu was proposed based on its sinuate trilobate leaves. Even more unusual leaf blade shapes are observable in 2 collections (Chuan Jing A 1737 and 5230) at KUN. Both have leaf blades that are lobed and dissected to an extreme degree for $P$. duclouxii, but in all other characters they conform with that species. Generally speaking leaf shape is an untrustworthy taxonomic character in many species of Convolvulaceae, and recognition of taxa based on it is unwarranted in D. duclouxii.

Corolla colour in D. duclouxii varies from white through pale yellow, lavender, pink, reddish, and blue to violet. Of 50 collections citing corolla colour, 13 report white or pale yellow and 37 report darker colours. This is very near a 3:1 ratio, which suggests a simple case of incomplete dominance in corolla colour. No correlation is apparent between corolla colour and geographic distribution or ecological factors. I believe the white flowered plants do not warrant taxonomic recognition. 


\section{Dinetus grandiflorus (Wall.) Staples - Fig. 9a-f; Map 5}

Dinetus grandiflorus (Wall.) Staples (1993) 199. - Dinetopsis grandiflora (Wall.) Roberty (1952)

27. - Porana grandiflora Wall. in Roxb. (1824) 41. - Type: Wallich s.n. (lecto K-Wal 1324.1,

A, excluding packet contents; isolecto CAL-Wal 1324.bis, sheet 314331), Nepal.

Porana stenoloba Kurz (1873) 136. - Type: S. Kurz s.n. (holo CAL; iso K), India, Sikkim.

Ipomoea cuspidata D.Don (1825) 98. - Type: Hamilton s.n. (not found), Nepal.

Perennial twiner to $7 \mathrm{~m}$ long, branches often pendulous. Stem terete, spirally striate, stramineous to brownish, \pm puberulent. Indumentum tawny yellowish to golden; hairs of axial parts simple, erect; laminar parts puberulous to velutinous, hairs simple, multicelled glandular, and 2-armed. Leaf petiole 2.8-8.5(-14) cm long, puberulent to villous or glabrous; blade narrowly to broadly cordate, rarely subhastate, (8.7-) $10.3-12.5(-17.7)$ by $(5.3-) 7.2-9(-13) \mathrm{cm}$, base usually deeply cordate, apex long attenuate to apiculate, mucronulate, adaxially darker brown, subglabrous, strigose or villous, abaxially paler tan, glabrous to velutinous. Inflorescence solitary (or paired), pendulous, 8-16(-23) $\mathrm{cm}$ long; bracts sessile, subulate to linear, $2-4 \mathrm{~mm}$, attenuate, yellowish pilose, early deciduous, lowermost bract sometimes foliaceous, petiole 4-9(-19) $\mathrm{mm}$ long, blade cordate to attenuate-ovate, $2.2-5.6$ by $1.4-3.7 \mathrm{~cm}$, more rarely bracts all lanceolatelinear, $15-35$ by $2-5 \mathrm{~mm}$; pedicels filiform, $6-16 \mathrm{~mm}$; bracteoles 2 , scale-like, golden pilose, usually deciduous, rarely accrescent and ovate to subcircular, 1-3 mm long, chartaceous, stramineous. Flowers showy, sweetly to spicily fragrant; buds elongate, \pm clavate, base swollen, apex acute. Sepals equal, subulate to triangular, occasionally elliptic-ovate, flat or medially keeled, $3.5-6$ by $0.5-1.25 \mathrm{~mm}$, base truncate, margins entire, apex acute, chartaceous, margins usually golden sericeous, rarely entirely sericeous or glabrous. Corolla (sub)salverform, $3-4.5$ by $2.8-4.4 \mathrm{~cm}$, membranous, mauve to rose or purple with a white eye and throat, rarely white or blue, tube narrow, base swollen, limb flaring abruptly, obscurely 5-lobed, lobes rounded-obtuse, apex tufted with golden hairs, otherwise corolla glabrous. Stamens equal, borne near corolla tube base; filaments $2-3 \mathrm{~mm}$ long, base puberulous to velutinous, glabrous above; anthers linear, 2-2.5 mm, yellow to cream-white; pollen 3-colpate, oblate spheroidal, 12-15 by 15-21 $\mu \mathrm{m}$, surface granulate. Pistil shorter than calyx; disc absent or narrowly annular; ovary ovoid to subglobose, c. $1 \mathrm{~mm}$ tall; style 3-4 mm long; stigma ellipsoid, entire or scarcely 2-lobed, green in life. Fruiting calyx loosely clasping utricle; sepals narrowly ellipsoid to linear-oblong, rarely narrowly obovate, unequal, concave, chartaceous, stramineous to pale brown, glabrous (rarely glandular pubescent), 3 outer 3.2-4.2 by $0.9-1.6 \mathrm{~cm}, 2$ inner $2.3-3.3$ by $0.5-0.7 \mathrm{~cm}$, base \pm naviculate, enclosing utricle, flaring distally, margins entire, flat or occasionally revolute, apex obtuse-rounded to retuse or emarginate, mucronulate. Utricle broadly obovoid to globose, (10-)14-16 by $9-13 \mathrm{~mm}$, apiculate by persistent $2-3 \mathrm{~mm}$ long style, chartaceous, olivaceous to stramineous with darker striations, glabrous. Seed ellipsoid, c. 11 by $9.5 \mathrm{~mm}$, smooth, dark brown, glabrous.

Distribution - Nepal, Sikkim, N West Bengal, Bhutan, and extreme SW China (Tibet).

Habitat - Rare to common in moist situations in cloud forests, deciduous forests, thickets, ravines and along watercourses; in association with Quercus L., Rhododendron L., Juglans L., and Codonopsis Wall. Mostly on north or west facing slopes at 1750-2600 m elevation. 


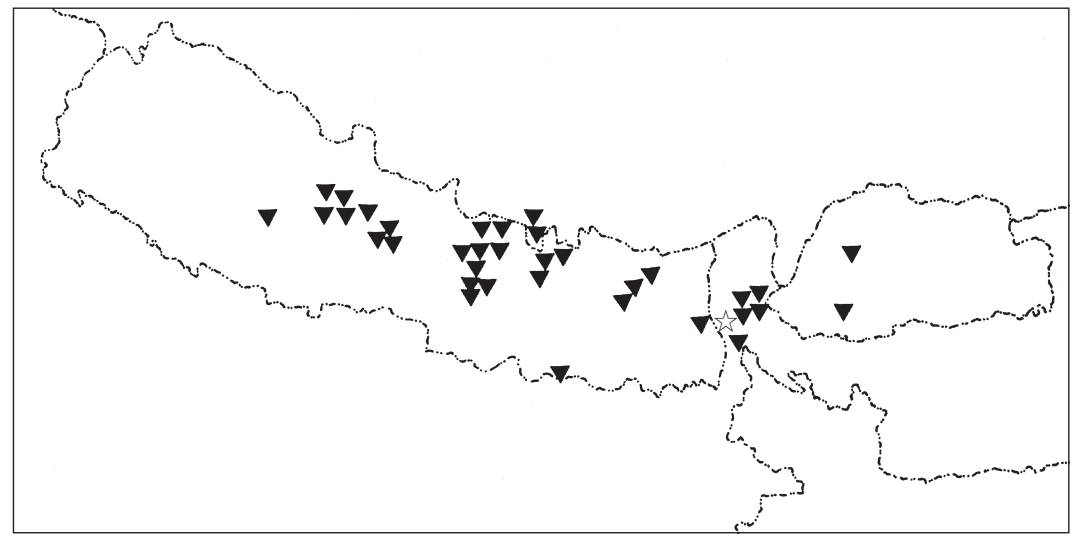

Map 5. Distribution of Dinetus grandiflorus (Wall.) Staples in sub-Himalayan Asia ( $\mathbf{\nabla}$ ); type locality for Porana stenoloba Kurz (它).

Phenology - Flowering: June (6), July (4), August (30), September (26), October (7), December (1). Fruiting: July (1), August (1), September (5), October (4), November (1).

Vernacular names - Chamera lahara, chamero laharo (Nepal); zang fei e teng (China).

Typification - The typification of Porana grandiflora, like that of other Wallich names, is complicated by the uncertain provenance and date of collection for much of the material distributed under the Wallich Catalogue numbers. The protologue for $P$. grandiflora states: "A native of the environs of Katumanda, especially the mountains of Shivapoor (commonly called Sheopore), blossoming during the rainy season, and ripening its fruit in January and February." (Wallich, in Roxburgh 1824: 42). Only one sheet in the Wallich herbarium, numbered 1324.1,A, agrees with the protologue. This sheet is a flowering collection of $D$. grandiflorus, gathered in "Sheopore, July 1821," probably by Wallich himself, since he collected in Nepal from late 1820 until early 1822 . This sheet bears a packet containing corollas of Ipomoea alba L.; in choosing sheet 1324.1, A as lectotype the packet contents are excluded. The Wallich herbarium at Calcutta has a duplicate sheet of this collection (Wallich 1324.bis, CAL 314331); it is here identified as an isolectotype. All other specimens of Wallich dist. 1324 I have examined differ from the protologue in terms of the place or date of collection, or have no label data beyond the Wallich catalogue number, and are thus ineligible as lectotypes.

Porana stenoloba Kurz was described as a distinct species based on its steel blue corolla, caudate foliaceous bracts, shallowly cordate leaves, and very narrow fruiting sepals. In comparison, the leaf blades of $D$. grandiflorus range from shallowly to deeply cordate, with sinuous or distant lobes, the bracts are usually deciduous but occasionally persistent and notably foliaceous (e.g., Saulière 767, G.H. Cave s.n.), and the corolla colour ranges from white through pink, mauve, and blue to violet. Thus, these character states for $P$. stenoloba all fall within the range of variation I accept for $D$. grandiflorus. There remain only the linear-oblong fruiting sepals as a diagnostic character for P. stenoloba. 
Kurz (1873) described his new species from a single collection he made in Sikkim; only one further collection (C.B. Clarke 36065) resembling it has become available since then. The type specimens conserved at CAL and K have what appear to be fruits enclosed by 5 enlarged sepals, $20-30$ by $3-5 \mathrm{~mm}$; a few corollas are still present on the CAL specimen. However, upon dissection no fruits were found inside the accrescent calyces on the type. I interpret these collections as individuals of D. grandiflorus with abnormally developed sepals. Dinetus grandiflorus has accrescent sepals as narrow as 5-9 $\mathrm{mm}$ and the other morphological characters ascribed to P. stenoloba fall within the range of variation I accept for $D$. grandiflorus. Furthermore, the known range of $P$. stenoloba is confined to Sikkim, entirely encompassed by that of D. grandiflorus, thus there is no geographic basis for recognizing two taxa. I find no consistent grounds for maintaining this species and follow Bentham \& Hooker (1876: 876) in reducing $P$. stenoloba to synonymy.

Note - Dinetus grandiflorus is distinctive for its equal sepals with golden sericeous margins (entirely sericeous in Tibetan material), showy salverform corolla with a swelling near the base of the tube, equal stamens borne at the level of the swelling, and fruits without enlarged, reflexed bracteoles. The plants are softly puberulous or subglabrous, rarely velutinous, but never viscid glandular as is D. duclouxii.

\section{Dinetus malabaricus (C.B. Clarke) Staples, comb. nov. - Fig. 8m-q; Map 6}

Porana malabarica C.B. Clarke (1883) 223. - Type: Stocks \& Law s.n. distributed as '\# 3 Porana' (lectotype (here designated) K; isolectotypes BM, C, CAL, E, FI, G, GH, GOET [mixed with Evolvulus alsinoides], L, LE, M, MEL, MO, NY, P, S, W), India, Karnataka.

Porana racemosa auct. non Roxb. (1824): Dalzell \& Gibson (1861) 162.

Subglabrous twiner several meters long. Stems terete, stout, striate or verruculose, stramineous to purplish brown. Indumentum on axial parts velutinous or tomentose, hairs simple; laminar structures strigose, hairs simple, rarely some 2- or 3-armed, erect hairs. Leaf petiole terete, 2.4-7 cm long, subglabrous; blade broadly cordate, $6.8-12$ by $4.2-7.4 \mathrm{~cm}$, base cordate, sinus deep, broad, apex abruptly acuminate to apiculate, adaxially darker brown, glabrous or sparsely strigose, abaxially paler tan, hairs especially dense along margins and on veins. Inflorescence lax, 12-20 cm long, slightly longer in fruit, axis stout, subglabrous; lower bracts sessile and amplexicaule, or petiolate, petiole $2-18 \mathrm{~mm}$ long, blade ovate to cordate, $3-5.5$ by $1.7-3.7 \mathrm{~cm}$, base cordate, apex apiculate to acuminate, persisting in fruit; upper bracts sessile, attenuateovate to lanceolate, $5-10$ by $2-5 \mathrm{~mm}$, deciduous; uppermost bracts linear, $2-4 \mathrm{~mm}$ long, deciduous; bracteoles 2 , minute, immediately subtending calyx, sparsely sericeous or glabrous, deciduous or persisting, enlarged to 1-3 mm long; pedicels filiform, 2-3 $\mathrm{mm}$, elongating to 6-12 $\mathrm{mm}$ in fruit, velutinous to sericeous. Flowers small; buds slenderly fusiform, attenuate at both ends, 5-6.5 mm long, apex acute. Sepals equal, lanceolate, $2-3$ by $1 \mathrm{~mm}$, base truncate, margins entire, apex attenuate, chartaceous, sparsely golden sericeous. Corolla slenderly funnelform, diaphanous, white, 7-9(-10) by $5-9(-11) \mathrm{mm}$, tube widening gradually, limb spreading abruptly, deeply 5-lobed, lobes broadly elliptic to ovate, apically obtuse to acute, tufted with tawny hairs, corolla otherwise glabrous. Stamens unequal, 1-2.5 mm long, included; filaments glabrous or bases sparsely pilose; anthers ovoid-sagittate, $<0.5 \mathrm{~mm}$ long; pollen 3-colpate, 


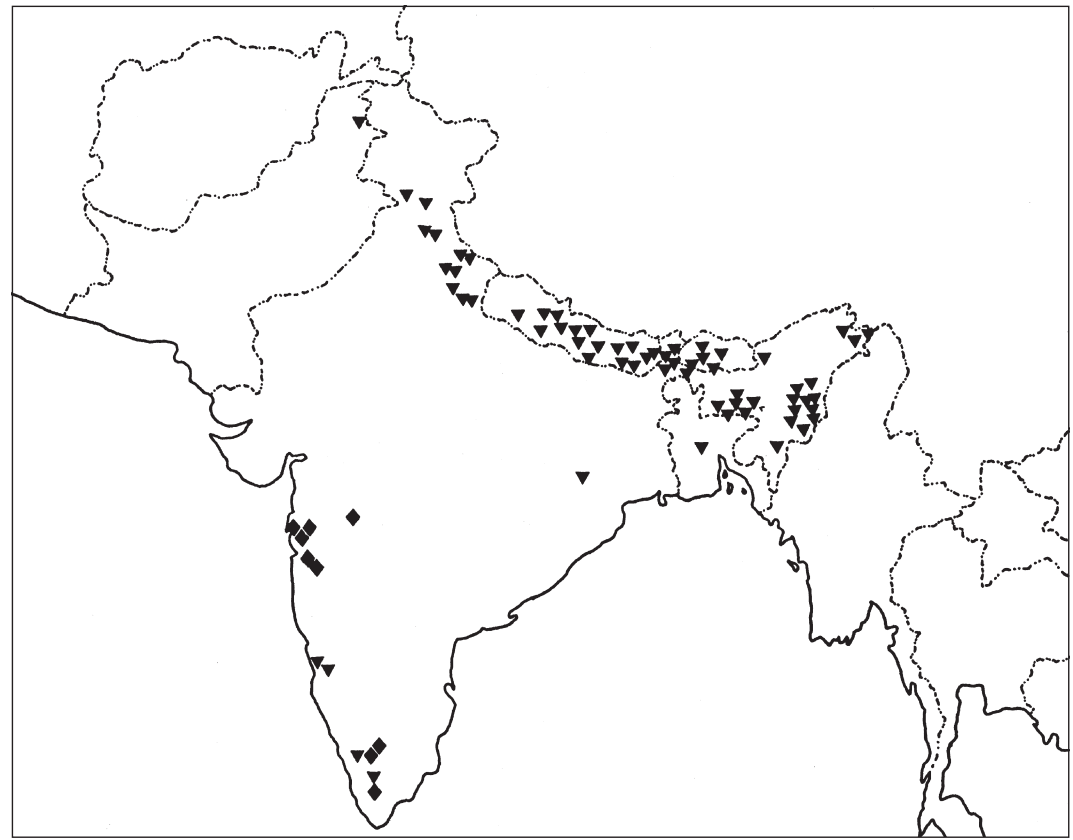

Map 6. Distribution of Dinetus racemosus (Roxb.) Buch.-Ham. ex Sweet $(\boldsymbol{\nabla})$ and D. malabaricus (C.B. Clarke) Staples $(\bullet)$ in the Indian subcontinent.

spheroidal, c. $15 \mu \mathrm{m}$ diam., surface psilate. Pistil c. $2 \mathrm{~mm}$ long, included; disc annular, tan; ovary attenuate-ovoid, $<1 \mathrm{~mm}$ tall, tapering into style; style c. $1 \mathrm{~mm}$ long; stigma clavate, apically emarginate to slightly bilobed, greyish. Fruiting calyx loosely clasping utricle (reflexed at maturity?), sepals all enlarged \pm equally, inner 2 narrower than outer 3, elliptic to narrowly obovate-spatulate, occasionally ovate to lanceolate, $17-23.5$ by $7-12.5 \mathrm{~mm}$, base truncate, margins entire, flat, apex obtuse, rounded, or retuse and mucronulate, chartaceous, stramineous to brownish or purplish, glabrous (rarely sparsely sericeous). Utricle ellipsoid, widest near middle, (8-)10-13(-14) by 4-5.5 mm, apex acute or obtuse, apiculate with persistent style base, chartaceous, stramineous to brownish tan, glabrous. Seed ellipsoid to obovoid, 6-8 by 3-4 mm, brown to reddish brown, smooth, glabrous.

Distribution - India (Maharashtra, Karnataka, Tamil Nadu).

Habitat - Rare to abundant in dry fields, Carissa scrub, forest margins and along roadsides, at 1000-1500 m elevation.

Phenology - Flowering: October (6), November (2), December (1). Fruiting: January (1), March (1), October (4), November (3).

Vernacular names - Bowri, gariya (Marathi, ex Talbot 1894: 149).

Notes - Dinetus malabaricus is distinctive for its elliptic to narrowly obovatespatulate fruiting sepals and ellipsoidal utricle. Overall, the plants have a more robust aspect than $D$. racemosus, with stouter stems, thicker leaf blades, noticeably larger fruiting sepals and utricles. Admittedly, this gestalt is not easily quantifiable, but the plants are recognizable after one has become familiar with the morphological variability 
of both taxa. The shape of the fruiting sepals and utricle also serves to differentiate D. malabaricus from D. rhombicarpus and D. truncatus, the nearest relatives of this species within the 'Dinetus' species group.

The distribution of D. malabaricus in southern peninsular India is entirely disjunct from that of D. rhombicarpus (north-eastern India and upper Myanmar) and of D. truncatus (north-eastern India across to eastern China). The range of D. racemosus marginally overlaps that of $D$. malabaricus but they are mostly allopatric. Clarke (1883) considered that these taxa might be varieties of $P$. racemosa, but rejected this in favour of species rank for each. Based on the distinctive fruiting characters and the almost completely allopatric distribution of these 4 taxa I also recognize them at species rank. Further study is needed to verify this placement. In particular, cytological study of D. malabaricus might prove instructive.

\section{Dinetus racemosus (Roxb.) Buch.-Ham. ex Sweet - Fig. 8a-g; Map 6-8}

Dinetus racemosus (Roxb.) Buch.-Ham. ex Sweet (1825) t. 127. - Porana racemosa Roxb. (1824) 41. - Type: Roxburgh s.n. sub Wallich Catalogue 1326E.1 (lecto K-W), India, Calcutta Botanic Garden.

Porana cordifolia Ledeb. (1824) 6. - Type: Herb. Ledebour s.n. (lecto LE; isolecto LE, W), Estonia, cultivated in hort. bot. Dorpat.

Porana racemosa J. Jacq. in Sprengel (1825) 614; J. Jacq. (1844) 11, t. 165, non Roxb. (1824). - Type: Wallich Cat. 1326 (lecto here chosen: W; isolecto LE, S, W), Nepal.

Porana dichotoma Buch.-Ham. ex D.Don (1825) 99, nomen pro syn., invalid under Art. 34.

Porana elegans Zoll. (1846) 571. - Type: Zollinger distr. 2560 (lecto here chosen: A; isolecto BM, G, LE, P), Java.

Porana gagnepainiana H. Lév. (1916) 58. - Type: E. Maire s.n. (holo E; iso A, G, W), China.

Porana racemosa Roxb. var. tomentella C.Y. Wu in Wu \& Li (1965) 103, t. 33, f. 4. - Type: C.W. Wang 80276 (holo KUN; iso A), China.

Porana racemosa Roxb. var. violacea C.Y. Wu in Wu \& Li (1965) 103, t. 34, f. 1. - Type: T.T. Ÿ̈ 14179 (holo KUN; iso A, KUN), China.

Perennial (or annual) twiner to 3-5(-20) m long, sericeous or glabrous. Stem terete, smooth or striate, often minutely verruculose, stramineous to purplish, pubescent, later glabrate. Indumentum yellowish to silvery, axial parts: hairs simple and 2-armed; laminar parts: hairs simple on veins and along blade margins, 2- and 3-armed on blade surface. Leaf petiole 2.9-7.7 cm long, glabrous or puberulent; blade deeply cordate, $6-16.7$ by $3.3-9.4 \mathrm{~cm}$, basal sinus narrow, apex attenuate-acuminate, adaxially darker, strigose, abaxially paler, puberulous to tomentulose or rarely tomentose-sericeous. Inflorescence solitary (or paired), spreading, paniculate, 13-45 cm long; lower bracts petiolate, petiole 3-20 mm long, or sessile, amplexicaule, blade cordate, $2.6-4.6$ by $1.4-2.8 \mathrm{~cm}$, persistent; upper bracts $1.8-2.8$ by $0.9-2.2 \mathrm{~cm}$, diminishing to scales, deciduous; pedicel filiform, 4-7 mm; bracteoles 2, minute scales. Flowers fragrant; buds slenderly fusiform, (4-)5-7(-8) mm long, apex acute, tufted with yellowish gold hairs. Sepals lanceolate-linear, equal, $1-2$ by $<1 \mathrm{~mm}$, acute to attenuate, glabrous and dark coloured to densely silvery or golden sericeous. Corolla funnelform, white (rarely violet, see Notes), tube base yellow, membranous, (7-) $8-11$ by $(6-) 8-12(-13) \mathrm{mm}$, tube narrow, limb flaring, deeply 5-lobed or 5-parted, lobes obtuse, apiculate, glabrous inside and out except for abaxial tufts of hairs on lobe apices. Stamens unequal, 1.5-2.5 mm long; filaments adnate to corolla tube, base pilose, glabrous above; anthers c. 0.5 
$\mathrm{mm}$ long, white; pollen 3-colpate, prolate to obtuse rectangular, $18-20$ by $12-13(-15)$ $\mu \mathrm{m}$, surface psilate. Pistil equal to or just longer than calyx; disc absent; ovary ovoid, $<0.5 \mathrm{~mm}$ tall, smooth; style $1.5-2.5 \mathrm{~mm}$ long; stigma ellipsoid to claviform, apically emarginate or slightly bilobed. Fruiting calyx venose, reflexed; sepals spatulate to slenderly obovate, flat or slightly concave, $9-14(-18)$ by $2.5-4(-5) \mathrm{mm}$, margins entire, apex rounded or obtuse, apiculate, chartaceous, tan, brownish or purplish, inner surface opaque or slightly shiny, glabrous, outer surface opaque, puberulent or glabrous. Utricle pendant, slenderly ellipsoid to obovoid, 5-7(-9) by 3-4(-5) $\mathrm{mm}$, apex apiculate or acute, thinly chartaceous, fragile, tan to stramineous, basally sometimes with 5 darker brown-purple streaks, glabrous. Seed ellipsoid to subglobose, $3-5$ by 2.5-4 mm, reddish brown to dark brown, smooth, glabrous. Seedlings with visible hypocotyl; cotyledons ovate, apex acute or tridentate; chromosome number $\mathrm{n}=14$ (Manitz, 1983, as P. racemosa).

Distribution - Pakistan throughout N India, Nepal, Bhutan (Map 6), China (Map 7), Myanmar and Southeast Asia to Malesia (Map 8).

Habitat - Open sites in forests, thickets, scrub, on hillsides and along watercourses on diverse soil types (e.g., sand, limestone, humus, granitic, loam, schistaceous, rocky, 'terre rouge riche') at (50-)1000-2000(-3200) m elevation. Evidently weedy and now often associated with human habitations and disturbance.

Phenology - By geographic region:

Indian subcontinent, East to Bangladesh - Flowering: January (2), February (2), April (1), May (3), June (2), August (2), September (23), October (47), November (9).

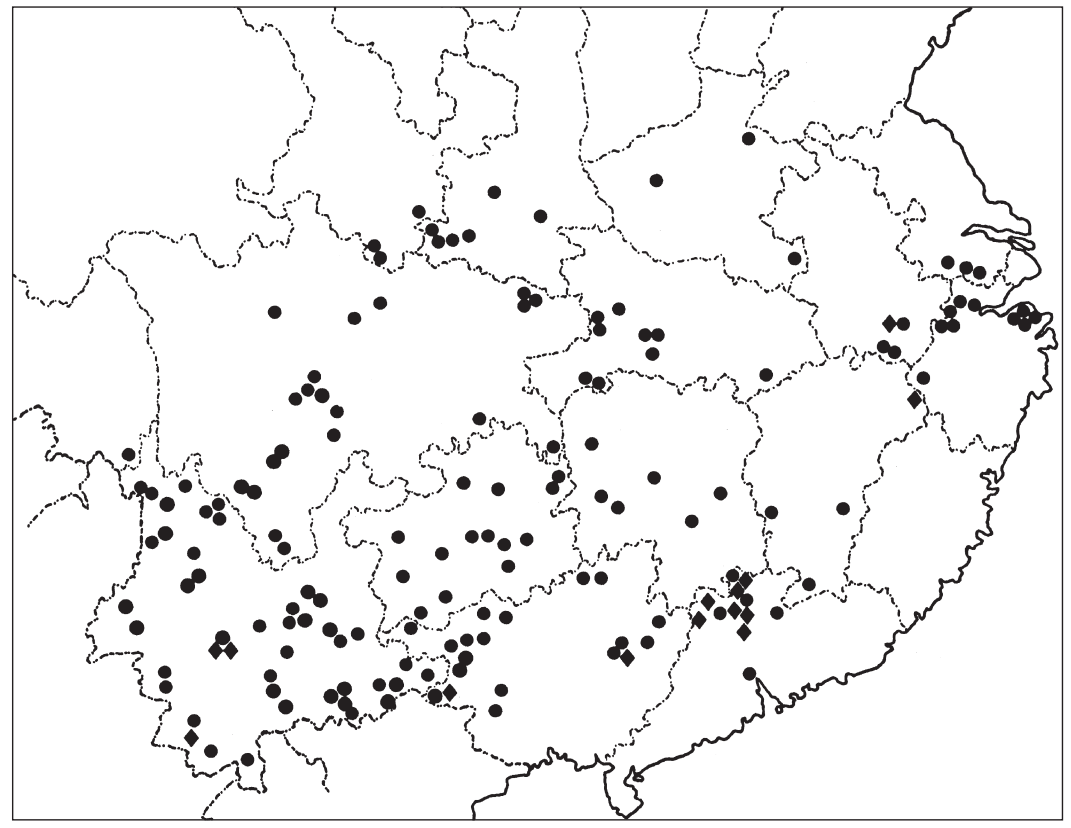

Map 7. Distribution of Dinetus racemosus (Roxb.) Buch.-Ham. ex Sweet (•) and D. truncatus (Kurz) Staples $(\diamond)$ in China. 
Fruiting: January (3), February (4), March (1), April (2), October (5), November (23), December (14).

Myanmar, Southeast Asia, Peninsular Malaysia - Flowering: April (2), July (1), September (5), October (16), November (14), December (8). Fruiting: January (4), April (2), October (1), November (6), December (15).

China - Flowering: February (4), May (2), June (2), July (3), August (8), September (83), October (56), November (10), December (2). Fruiting: April (1), July (2), August (1), September (10), October (58), November (38), December (16).

Insular Malaysia, Indonesia - Flowering: April (5), May (5), June (5), July (5), August (1), October (1). Fruiting: June (2), July (3), August (1), October (1).

Vernacular names - Snow creeper (Nepal, Bhutan); ma-ywe (Myanmar, Kachin); bai hua teng, xiao yuan bao (China); phung khruea daeng (Thailand, Chiang Mai); khua tak tenk (Laos); rendeng, srintil, tjloenga, tjoenlor (Java); bofa-bofa (Alor, Lesser Sunda Islands).

Typification \& Nomenclature - Three names were published in 1824 for this species: Porana racemosa Roxb. (1824) appeared between March and June 1824; P. racemosa

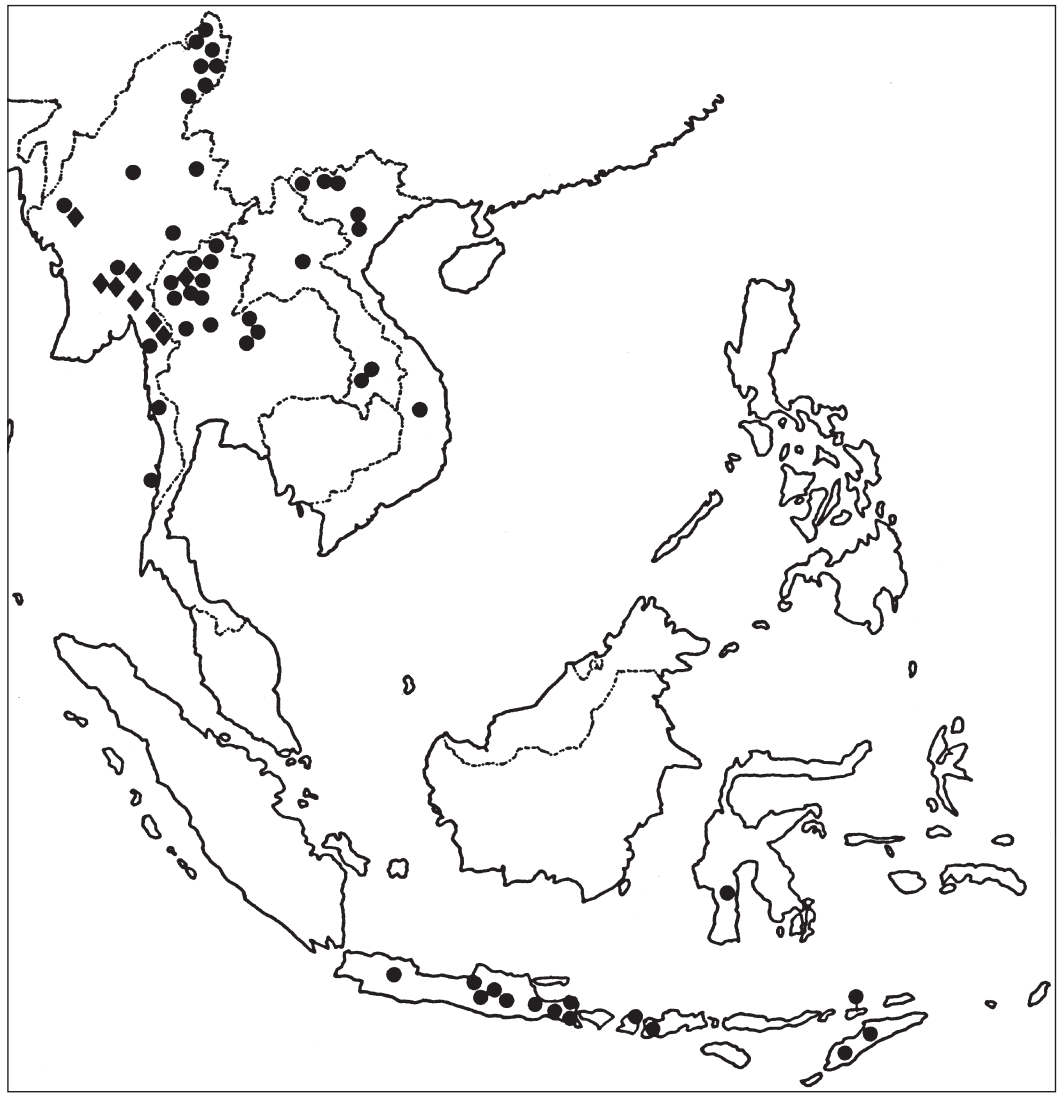

Map 8. Distribution of Dinetus racemosus (Roxb.) Buch.-Ham. ex Sweet (@) and D. truncatus (Kurz) Staples $(>)$ in south-eastern Asia and Malesia. 
J. Jacq. (in Sprengel, 1825) was actually published late in 1824; and P. cordifolia Ledeb. (1824) appeared on 6 December 1824.

Porana racemosa was first published as a nomen nudum by Roxburgh in 'Hortus bengalensis' (Roxburgh, 1814). Wallich (in Roxburgh, 1824) later took up the name and validated it by publishing Roxburgh's draft description in 'Flora indica'. Wallich did not typify the name. One element in the Wallich Herbarium at Kew conserved under Catalogue number 1326 has been authenticated as a Roxburgh specimen by L. Forman (pers. comm., 1993): the small label at the top left corner "Porana racemosa" is in Roxburgh's handwriting. This element (excluding the fruiting specimen mounted on the same sheet) has been chosen as the lectotype (Staples, 1993).

Notes - The characters diagnostic for D. racemosus are: a small, funnelform, deeply 5-lobed corolla; unequal stamens with almost the entire filament adnate to the corolla tube; an ellipsoid, scarcely bilobed stigma; narrowly obovoid to spatulate fruit sepals; and the ellipsoid utricle with an apiculate apex (Fig. 8g). Other members of the 'Dinetus' species group have characters that intergrade with $D$. racemosus; only the shape of the fruiting sepals and the utricle are reliable for distinguishing this species from others in the 'Dinetus' species group.

Dinetus racemosus is the core species in a group of 5 herbaceous perennial species that are widespread in tropical and subtropical Asia. Of the members of this group, only $D$. dinetoides is distinct from $D$. racemosus in terms of vegetative, floral, and fruit characters. Three other species (D. malabaricus, D. rhombicarpus, and D. truncatus) cannot be separated from $D$. racemosus at the present state of knowledge, based on the available collections, by vegetative and floral characters. Only fruiting sepal and utricle characters serve to conclusively differentiate these three species from $D$. racemosus.

Dinetus racemosus exhibits considerable variation in stem colour, leaf indumentum, bract morphology and duration, flower size, degree of filament fusion to the corolla, corolla colour, fruiting sepal shape and size, and utricle shape and size. Several variants have been recognized as distinct taxa, yet when these characters are examined across a wide sample (a large number of specimens from throughout the geographic range of the species) they do not vary in a correlated pattern that I can discern. I have reduced all segregates to synonymy and recognize a single variable species. Only one variant warrants specific comment.

Violet flowers (or corollas) have been reported in D. racemosus from collections made in Nepal, China, and Vietnam. Some of these records (e.g., Q.X. Liu 51376 (IBSC), Sino-Russian Exped. A0174 (YUKU)) are dubious because they are fruiting specimens with purplish calyces and a label that states "flower violet". I regard these as cases of poor field notation or inaccurate translation from Chinese into English. But in other cases the corolla is reported to be some shade of purple and there is nothing to contradict the label information. Such specimens are few and they are scattered throughout the continental Asian range of D. racemosus (e.g., Nepal, D.H. Nicolson 2369 (US); China, August, E. Maire s.n. (A, P), Sept., E. Maire s.n. (A, P), Y. Tsiang 12048 (IBSC); Vietnam, E. Poilane 26636 (A, P)). Wu in Wu \& Li (1965) described Porana racemosa var. violacea based on one such specimen (T.T. Yü 14179 (KUN)) from Muli Xian in Sichuan province. Because these purplish flowered collections are so few in number and they are scattered throughout the range of D. racemosus I regard them as individual variations in flower colour, and reduce Wu's variety to synonymy. 
Dinetus racemosus has several ethnobotanical uses across its geographic range. In China it is used for treating 'wind damage' and dyspepsia (Fang et al., 1986); the plant parts used and the method of preparation are not stated. In Laos, "... les jeunes feuilles sont comestibles les Laotiens les mangent avec du piment." (ex label Poilane 2080) and "... sont comestibles à l'état vert et à l'état sec." (ex label Poilane in herb. A. Chevalier 2375).

\section{Dinetus rhombicarpus Staples, spec. nov. - Fig. 10; Map 2}

Herba annua volubilis, similis D. truncato (Kurz) Staples et ad multos annos ea confusa, sed a sepalis fructificantibus ovatis ad basin plus minusve abrupte attenuatis, et utriculis late obtrulloidis apice obtusis vel rotundatis, differt. Flores ignoti. - Typus: C.B. Clarke 16602 (holo K; iso BM, CAL, FI, K, LE, SING, US), India, Assam.

Porana truncata auct. non Kurz (1873): C.B. Clarke (1883).

Herbaceous, subglabrous twiner to $2 \mathrm{~m}$ long. Stem terete, often minutely verruculose, stramineous to purplish brown, glabrous or sparsely pubescent in axillae near tips. Indumentum on axial parts: hairs 2-armed, simple, appressed, rarely some setose; laminar parts: hairs simple, straight, appressed. Leaf petioles $3.5-13 \mathrm{~cm}$ long, flattish; blade broadly cordate, $7.5-11$ by $4.6-8.2 \mathrm{~cm}$, basal sinus deep, broad, apex attenuateacuminate, adaxially darker brown, glabrous or sparsely strigose, abaxially paler greyish, glabrous. Inflorescence and flowers not seen. Infructescence a raceme or panicle, 12-27 cm long; fruits pendulous; bracts foliaceous, sessile, cordate-auriculate, lower ones $4.1-6.2$ by $2.1-3.6 \mathrm{~cm}$, both sides \pm shiny, glabrous, tardily deciduous, upper bracts similar, $1.8-3$ by $1.2-1.8 \mathrm{~cm}$, early deciduous; pedicels filiform, deflexed, (8-)11-13(-15) mm. Fruiting calyx reflexed, sepals enlarged \pm equally, inner 2 slightly narrower, ovate to ovate-elliptic, $(11.5-) 14-16(-18)$ by $(4.5-) 8-10(-11) \mathrm{mm}$, base \pm abruptly attenuate, margins entire, apex obtuse to rounded (rarely acute), usually mucronulate, stiffly chartaceous, outside brownish purple, inside paler, becoming translucent with age, glabrous or outside sparsely pubescent basally. Utricle broadly rhombic to broadly obtrulloid, $5-7$ by $6-8(-9) \mathrm{mm}$, stramineous, thickly chartaceous, smooth to coarsely wrinkled, with a spongy white mass inside between seed and fruit wall, glabrous. Seed globose, faintly keeled, 3-4 mm diam., surface slightly resinousmealy, dark brown to reddish brown.

Distribution - NE India and W Myanmar, perhaps also in Bangladesh.

Habitat - Rare to common at elevations ranging from 1300-2075 m, on slopes and along streams, in open forests.

Phenology - Flowering: none. Fruiting: May (1), October (1), November (3).

Vernacular name - He rut te (Myanmar, Chin State).

Typification - Clarke customarily designated duplicates of his collections with letters. I have seen 8 duplicates of Clarke 16602, two of them in K. The duplicate $16602 \mathrm{~A}$ is designated as holotype, while $16602 \mathrm{~F}$ is an isotype.

Notes - Dinetus rhombicarpus is most similar morphologically to D. truncatus and D. malabaricus in the 'Dinetus' species group. For many years it was confused with $D$. truncatus (q.v.) and had been considered conspecific with that species. While the two are similar, $D$. rhombicarpus is unique in terms of its ovate to ovate-elliptic fruiting sepals with \pm abruptly attenuate bases, and in its broadly rhomboid to broadly obtrulloid utricles. The specific epithet denotes the latter character. 

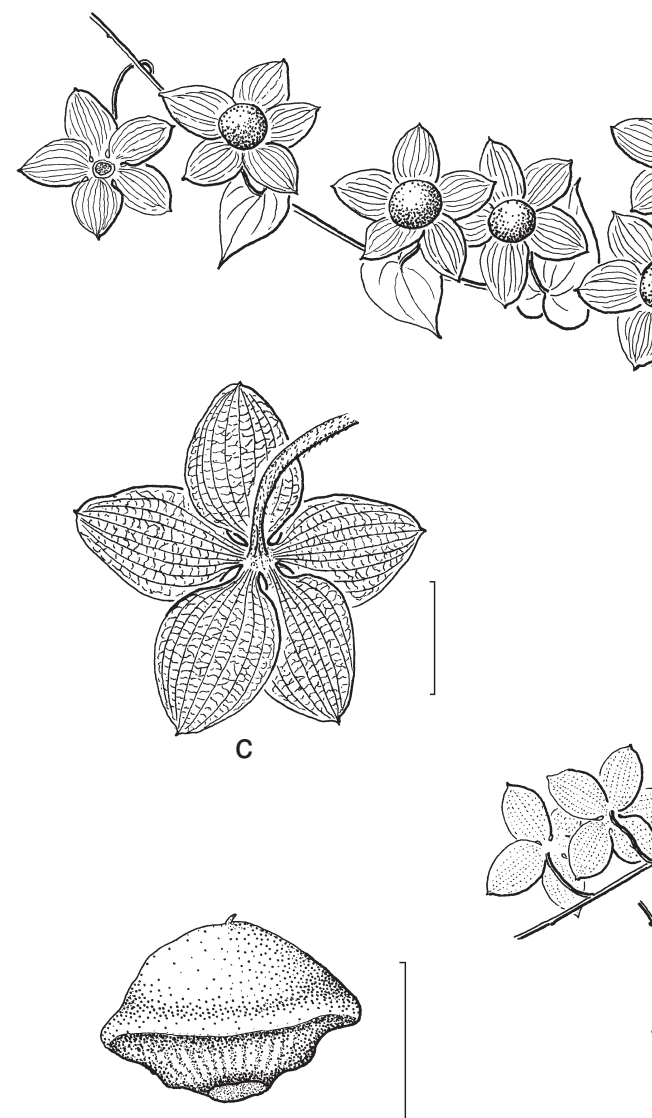

d
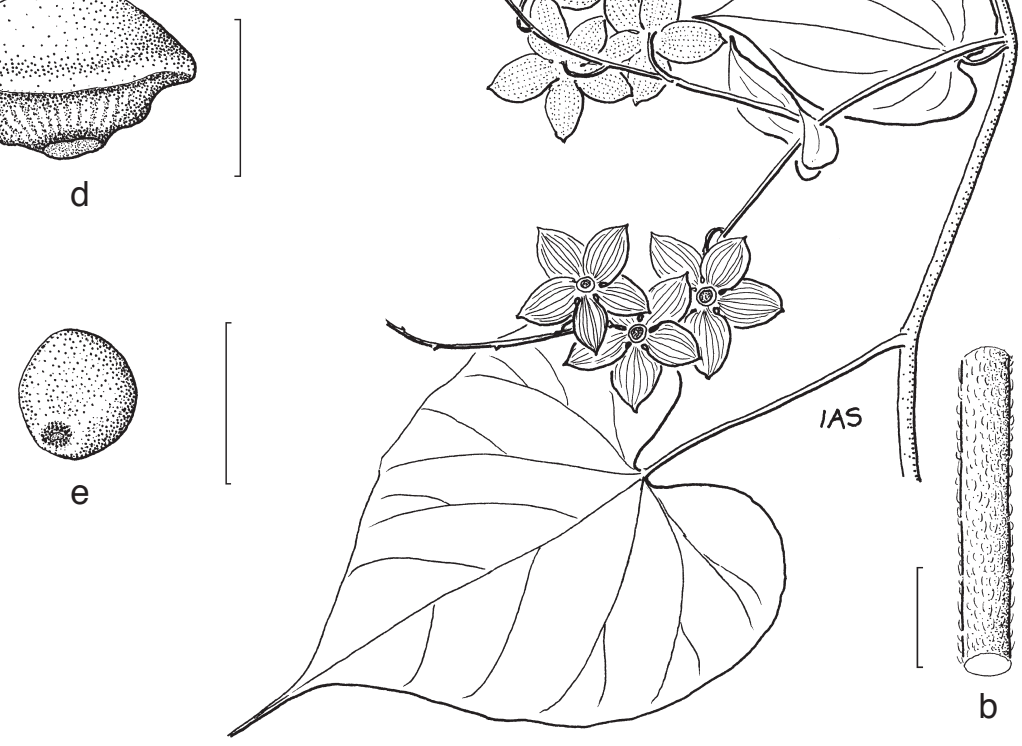

a
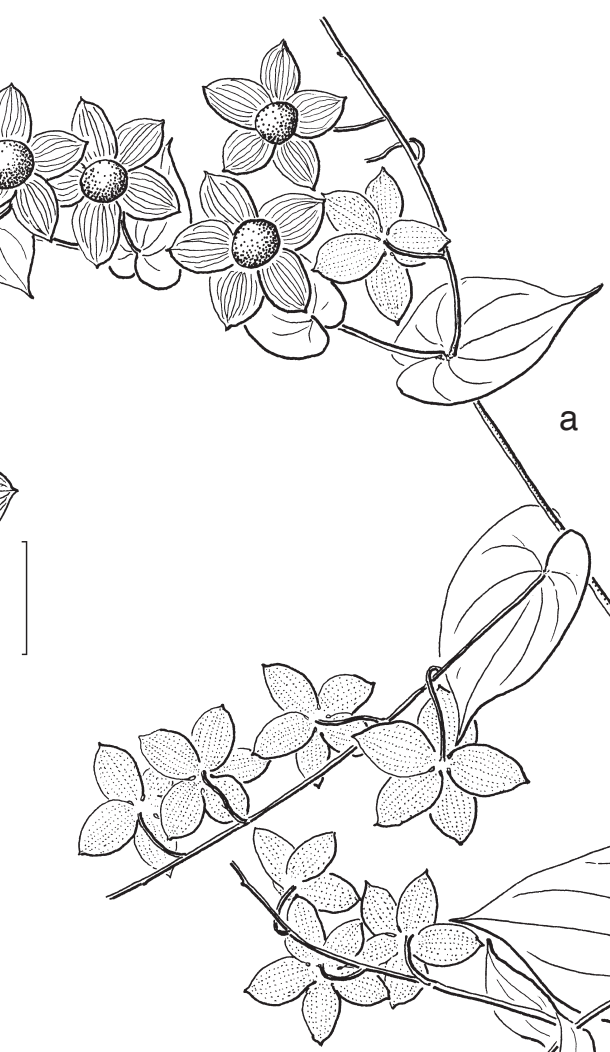

Fig, 10. Dinetus rhombicarpus Staples. a. Habit; b. stem; c. fruiting calyx from the outside; d. utricle; e. seed (all: Dickason 7706). Scale bars: $\mathrm{a}=5 \mathrm{~cm} ; \mathrm{b}=2 \mathrm{~mm} ; \mathrm{c}=1 \mathrm{~cm} ; \mathrm{d}, \mathrm{e}=5 \mathrm{~mm}$ 
Dinetus rhombicarpus remains under-collected and consequently it is little better known today than it was in 1873 when Kurz first considered it a distinct species, one which he hesitated to describe until better material was available. The flowering stages remain unknown and only fruiting material, some including vegetative organs, has been collected since then. The fruit morphology and the distinctive shape of the fruiting sepals, however, indicate that this is a distinct species; flowering material may provide additional taxonomic characters.

\section{Dinetus truncatus (Kurz) Staples - Fig. 8h-1; Map 7, 8}

Dinetus truncatus (Kurz) Staples (1993) 200. - Porana truncata Kurz (1873) 136. - Type: F. Mason 17 (lecto K; isolecto HBG), Myanmar; non P. truncata (Göpp.) Schimp. in Schimper $\&$ Schenk (1890), a fossil taxon.

Porana racemosa Roxb. var. sericocarpa C.Y. Wu in Wu \& Li (1965) 103, t. 33, f. 3. - Type: P.Y. Chiu (Qiu Bing-yun) 53220 (holo KUN; iso KUN, PE), China.

Herbaceous twiner to $2 \mathrm{~m}$ long. Stems terete, slightly verruculose with blackish dots, stramineous to reddish brown, sparsely sericeous, glabrate. Indumentum on axial parts sericeous: hairs simple or 2-armed; laminar parts: hairs simple or 3-armed. Leaf petiole terete, $3.8-6.4 \mathrm{~cm}$ long, base pulvinate; blade broadly ovate-cordate, $8.3-9.5$ by 5.6-6.9 $\mathrm{cm}$, base cordate, sinus deep, broad, apex \pm caudate, adaxially darker brown, glabrous or sparsely strigose, abaxially sparsely sericeous along veins with simple hairs, sparsely stellate on lamina. Inflorescence racemose or paniculate, bracteose; bracts foliose, sessile and amplexicaule, ovate-cordate, $3.6-3.9$ by $2-2.4 \mathrm{~cm}$, persisting and enlarging. Flower buds acute; apex minutely tufted with shining hairs. Sepals clasping corolla base, lanceolate, equal, 2-2.5 mm long, sparsely sericeous, apex tapering-acute, often slightly recurved. Corolla slenderly funnelform, 7-10 by $9-11 \mathrm{~mm}$, glabrous outside, tube flaring gradually, limb 5-parted, lobes broadly ovate, about as long as tube, faintly 3-veined, apex mucronate. Pistil shorter than calyx (not visible after corolla drops off). Infructescence lax, 15-23 cm long; bracts 3.6-5 by $2.3-2.8 \mathrm{~cm}$, purplish, chartaceous, adaxially \pm shiny, abaxially opaque, glabrous or sparsely sericeous; pedicels filiform, (7-)10-11(-15) mm, deflexed. Fruiting calyx spreading, sepals all enlarged \pm equally, slenderly elliptic to oblong, (10-)17-21 by (3-)4-5 mm, margins entire, apex obtuse to rounded, mucronulate (rarely apiculate), stiffly chartaceous, purplish tan to brownish, glabrous or sparsely pubescent toward base, along margins, and on veins. Utricle pendulous, inflated, broadly obovoid to rhomboid, often 5-angled, 4-6(-8) by 4-6.5(-8) $\mathrm{mm}$, base with an annular lip, tapering smoothly upward, apex truncate or depressed concave, chartaceous, wrinkled or smooth, stramineous to rusty-brown, often darker on $3(-5)$ angles, glabrous or puberulent with yellowish hairs, filled with a spongy, whitish mass between seed and pericarp. Seed ellipsoid to subglobose, $3-5$ by (2-)3-4 mm, yellowish brown to dark red-brown, smooth to coarsely wrinkled, glabrous. Seedling hypocotyl visible above ground; cotyledons ovate, apex acute to tridentate.

Distribution - This species ranges from eastern Myanmar across northern Thailand and in a wide arc across southern China as far as Anhui Province in central China; it very likely occurs in Laos but no material has been seen from there.

Habitat - Rare to locally abundant in damp clearings in conifer/hardwood forests, along roadsides, in thickets and old taungyas (cultivated land) at elevations ranging from $700-2500 \mathrm{~m}$. Soils are variously noted as sandy, silty, clay, and fertile. 
Phenology - Flowering: January (1), October (2). Fruiting: October (6), November (10), December (5).

Vernacular name - Khya nám myg (northern dialect, Thailand).

Typification - The taxonomic concept for Porana truncata has been somewhat obscure since Kurz (1873) named the species, based on fruiting material only. I have identified syntypes in the herbaria at CAL, HBG, and K. No illustration accompanied the description and the type collections at HBG and $\mathrm{K}$ were inserted in the general herbaria, labelled P. racemosa. In his observations for this species Kurz mentioned that, "another species nearly allied to the above" was represented by fruiting material collected in East Bengal (Griffith 5876). This number lacks both leaves and flowers and Kurz declined to name it.

Clarke (1883: 223) treated Griffith 5876 as a specimen of Porana truncata, indeed it is the only specimen he cited for this species. His description of the utricle of P.truncata agrees with Griffith 5876, but is quite different from that of the type specimens of P. truncata. In the Kew herbarium a sheet of Griffith 5876 was filed in the type folder for $P$. truncata whereas the actual type material of $P$. truncata at Kew was not recognized as such. Because the Griffith collection was more widely available to botanists Griffith 5876 was misinterpreted as representative of $P$. truncata. In fact it is a distinct species treated in this revision as $D$. rhombicarpus.

Notes - Dinetus truncatus is recognized by its distinctive larger, truncate, often 5-angled and purplish streaked utricle, and elliptic-oblong, purplish fruiting sepals. The purplish streaks on the utricle correspond to gaps between the sepals where the fruit wall is exposed to light. The utricle is bladdery and inflated and the space between the fruit wall and the seed is filled with a whitish, spongy material.

Dinetus truncatus is morphologically similar to both D. racemosus and D. malabaricus; indeed Clarke (1883) suggested the three might be varieties of a single species. Within the genus Dinetus, the members of the 'Dinetus' group are separable based on characters of the fruiting calyx and utricle such as sepal shape, size, coloration, utricle shape, degree of separation between the pericarp and the single seed, and the coloration and pubescence of the utricle. The species in the 'Dinetus' group share the common features of 5 equally enlarged sepals that are reflexed at maturity, and a valvate aestivation pattern for the calyx. This is evident in the fruit, but less easily seen in the flower due to the small size (1-2 mm) of the sepals.

I am unable to associate the distinctive fruiting stage of $D$. truncatus with the flowering stage, which seems to intergrade completely with that of $D$. racemosus. Only two flowering specimens are here referred to D. truncatus, albeit with some hesitation. Sin 1210 was cited by Wu in Wu \& Li (1965) as a paratype of P. racemosa var. sericocarpa. The holotype specimen for Wu's variety is in fruit; it agrees fully with the concept of $D$. truncatus and on this basis Wu's variety is reduced to synonymy. But there is nothing to distinguish the flowers of $\operatorname{Sin} 1210$ from those of $D$. racemosus. I provisionally refer this collection to D. truncatus. The second collection, Parish 178, legit 1859 (K), has five short pieces mounted on the sheet: two with flowers and three with fruit; all parts are glued tightly on the sheet and so details of the internal parts are unavailable. The fruits are certainly D. truncatus and the flowers, if taken from the same plant and not a mixed gathering, can be assumed to be conspecific. They are the basis for the foregoing description but do not differ significantly from those of D. racemosus, which 
is quite variable. Further study, preferably a common garden experiment, is needed to ascertain how the flowers of $D$. truncatus differ from those of D. racemosus.

\section{DUPERREYA}

Duperreya Gaudich. (1829) 452. - Type: Duperreya sericea Gaudich.

Slender, suffrutescent, sericeous twiners. Roots fibrous. Leaf petiole terete, blade linearoblong, entire, chartaceous, venation with a single pair of secondary veins departing above blade base. Flowers solitary, axillary; bracteoles 2, sepaloid, borne just below calyx, persisting. Sepals 5, free, quincuncial, (sub)equal, about 3/4 as long as corolla. Corolla campanulate (or broadly funnelform), subentire to 5-toothed, contortuplicate, lobe apices with abaxial hair tuft (rarely sparsely sericeous along interplicae), otherwise glabrous. Stamens 5, included, filaments fused below to corolla tube, free above, glabrous; anthers ellipsoid, longitudinally dehiscing prior to anthesis; pollen 3-colpate, nonspinose. Pistil included or exserted; disc annular; ovary 1- or 2-celled; ovules 2, basal, erect; style terminal, simple; stigma 1, biglobose. Fruiting calyx with all sepals equally enlarged, scarious, veins 3 or 5, parallel, longitudinal. Utricle chartaceous, \pm enclosed in accrescent calyx. Seed 1, smooth, glabrous; hilum basal, circular.

There are 2 species of Duperreya, both endemic in Australia. Gaudichaud named the genus in honour of Louis-Isidore Duperrey, an officer of the marines attached to Commander Freycinet's hydrographic expedition, in recognition of his diligence as a collector of plants.

\section{KEY TO THE SPECIES}

1a. Sepals elliptic to lanceolate, only partly covering corolla tube; in fruit becoming elliptic-oblong to narrowly ovate $\ldots \ldots \ldots \ldots \ldots \ldots \ldots \ldots$ 11. D. commixta

b. Sepals ovate to broadly elliptic, completely covering corolla tube; in fruit becoming

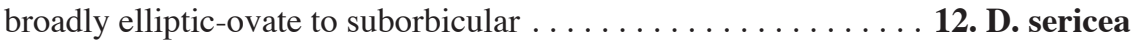

\section{Duperreya commixta (Staples) Staples, comb. nov. - Map 9}

Porana commixta Staples (1987b) 52. - Type: P.G. Wilson 8965 (holo PERTH; iso A, CANB, K), Australia.

Perennial twiner to $4 \mathrm{~m}$, silvery grey-sericeous. Stems woody, cylindrical, 3-5 mm diam., brownish red with sparse paler lenticels, glabrate, bark peeling with age. Indumentum of 2-armed hairs up to $1 \mathrm{~mm}$ long, arms mostly equal, appressed, occasionally unequal and erect. Leaf petiole $<1 \mathrm{~mm}$ long; blade linear to narrowly lanceolate or narrowly oblong, $16-57$ by $1.5-5 \mathrm{~mm}$, base cuneate to obtuse, apex acuminate to acute, rarely obtuse or rounded, usually mucronulate, adaxially darker, sparsely sericeous, abaxially sericeous. Flower pedicel filiform, 6-8 mm long; bracteoles subopposite, narrowly elliptic-lanceolate, subequal, $2-5$ by $<1 \mathrm{~mm}$, slightly enlarging in fruit; buds ellipsoidal, apex obtuse, \pm sparsely sericeous. Calyx incompletely covering corolla tube; sepals equal in length, outer 2 broader, narrowly elliptic to tapering lanceolate, $5-7$ by 1-2.5 mm, base rounded to truncate, margins entire, apex acute, chartaceous, outside 
sparsely pubescent, shining, inside glabrous; veins 3 . Corolla campanulate, $7-13$ by 8-15 mm, membranous, blue, purple-blue, purple or white, limb entire to lobed, lobes obtuse, apiculate, glabrous (rarely subsericeous along interplicae). Stamens (sub)equal; filaments 2-3 mm long; anthers 1.5-2 mm long, introrse, dehiscing in bud; pollen 3-colpate (rarely 3-zonocolpate), prolate spheroidal, $32-33$ by $27-31 \mu \mathrm{m}$, surface psilate. Pistil just exceeding corolla tube, glabrous; disc dark brown; ovary ovoid-ellipsoid, c. $1 \mathrm{~mm}$, unilocular; style filiform, 3.5-5 mm long, sometimes jointed above ovary; stigma $<1 \mathrm{~mm}$ diam., wrinkled. Fruiting calyx spreading; narrowly elliptic-oblong to narrowly ovate, $11-15(-20)$ by $3-6(-10) \mathrm{mm}$, stramineous to tan, glabrate; veins 5 . Utricle ellipsoid, apiculate, $5-5.5$ by $3.5-4.5 \mathrm{~mm}$, brownish tan with darker striations, smooth, glabrous or apex with a few hairs. Seed ellipsoid to subspherical or obovoid, c. $4 \mathrm{~mm}$ diam., reddish brown; hilum c. $1 \mathrm{~mm}$ diameter.

Distribution - Australia (Western Australia, SE Queensland, and NW New South Wales).

Habitat - Inland situations in dry habitats near pools and watercourses: on rocky slopes in dead scrub, mulga, bloodwood, among lancewood escarpments, in Dodonaea thickets, over rocks, and along forest margins. Soil types recorded as red sands, loamy or sandy-clay soils, and crevices in limestone-conglomerate cliffs. At 0-200 m elevation.

Phenology - Flowering: July (7), August (11), September (6), October (6). Fruiting: February (2), April (1), September (1), October (3), November (2).

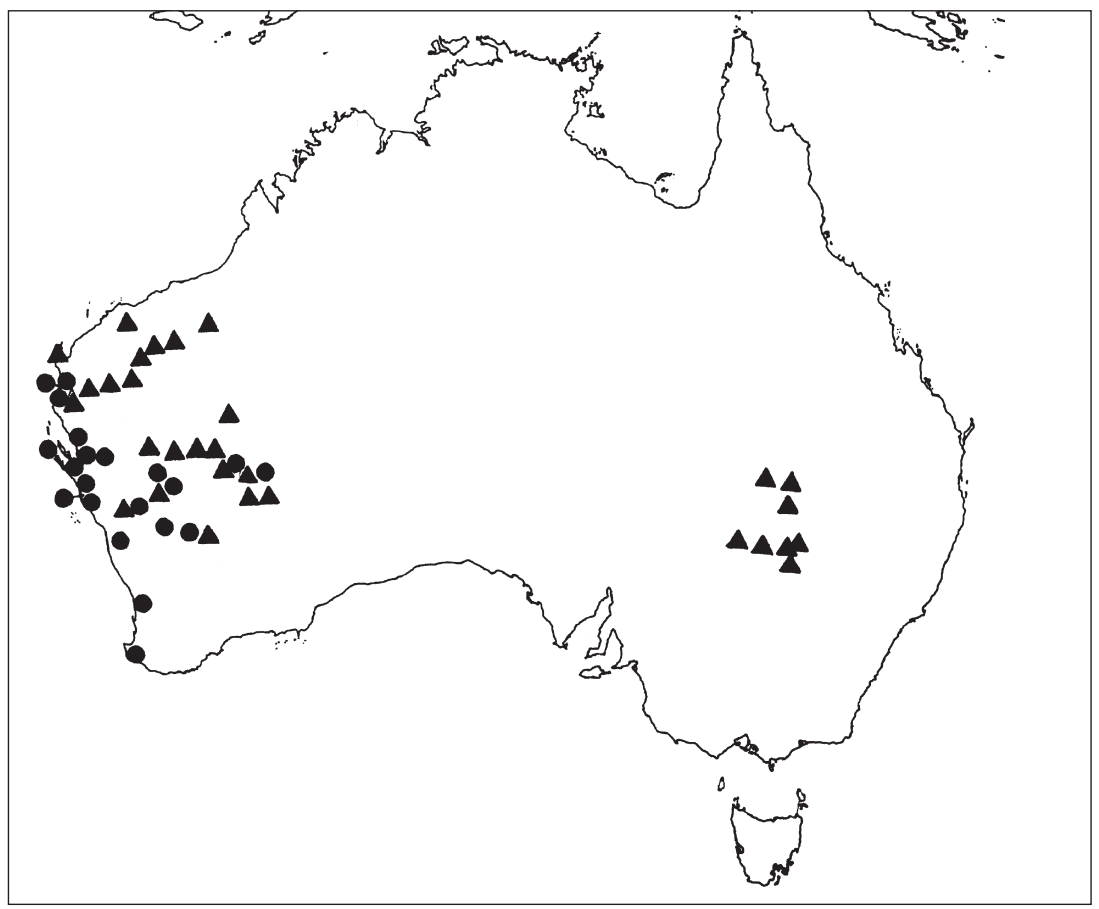

Map 9. Distribution of Duperreya commixta (Staples) Staples (ム) and D. sericea Gaudich. (•) in Australia. 
Notes - The diagnostic characters for $D$. commixta are: the narrowly elliptic to lanceolate sepals, widest below the middle and gradually tapering distally; the calyx incompletely covering the lower corolla (the corolla tube is visible between the sepals); the biglobose stigma, each lobe directed more or less horizontally from the style apex; the fruiting sepals narrowly elliptic-oblong or narrowly ovate. Dried material of D. commixta has a silvery-grey aspect due to the colour of the indumentum.

Plants from around Cobar in New South Wales have wider fruiting sepals, on average, than plants from Western Australia or Queensland. These plants are intermediate in this character between $D$. commixta and $D$. sericea, but in other respects they are typical of the former species.

The range of $D$. commixta overlaps in Western Australia with that of $D$. sericea. The former is found primarily on inland sites, while D. sericea has a more coastal distribution.

\section{Duperreya sericea Gaudich. - Fig. 11; Map 9}

Duperreya sericea Gaudich. (1829) 452. - Porana sericea (Gaudich.) F. Muell. (1868) 100. - Type: Gaudichaud s.n. (holo P; iso G), Australia. Ipomoea modesta F. Muell. (1860) 22. - Type: Oldfield s.n. (holo MEL; iso K), Australia.

Perennial twiner to $1.6 \mathrm{~m}$ long, golden-grey sericeous. Stem terete, smooth or sparsely lenticellate or verrucate, glabrate. Indumentum of 2-armed hairs, arms equal, opposite, appressed, stalk short. Leaves solitary or axillary shoots developed and leaves appearing fascicled; petiole $<1 \mathrm{~mm}$; blade attenuate-lanceolate, linear-oblong, to narrowly elliptic, $21-65$ by $1.5-6 \mathrm{~mm}$, base rounded to cuneate, margins entire or slightly involute, apex acute to acuminate (to rounded or obtuse), sometimes mucronulate, adaxially darker, sparsely sericeous, margins subglabrous, abaxially golden-grey sericeous; venation with 1 strong basal pair and 4-6(-8) weak distal pairs of secondary veins. Flower pedicel filiform, $9-11 \mathrm{~mm}$, to $15-18 \mathrm{~mm}$ in fruit; bracteoles subequal, tapering elliptic to lanceolate, $3-4$ by $1-1.5 \mathrm{~mm}$, chartaceous, sericeous outside, glabrous inside, to $5 \mathrm{~mm}$ long in fruit; buds ovoid (to ellipsoid), apex acute (to obtuse). Calyx covering corolla tube; sepals (sub)equal in length, outer 2 slightly wider, broadly ovate to elliptic to broadly elliptic, $5-8$ by $3-5.5 \mathrm{~mm}$, base obtuse to rounded, margins entire, apex acute to acuminate, chartaceous, smooth, outside golden sericeous, inside glabrous; veins 3 or 5. Corolla campanulate (or broadly funnelform), (6-)8-10(-11) by (10-)13-15(-16) $\mathrm{mm}$, membranous, pale to dark blue or blue-violet with a white centre, limb entire to 5-toothed, interplical areas sparsely sericeous, plicae and corolla interior glabrous. Stamens equal; filaments c. $5 \mathrm{~mm}$ long; anthers 1-2 mm long, extrorse, whitish, bases free and slightly divergent; pollen oblate spheroidal, $22-25$ by $24-31 \mu \mathrm{m}$, surface psilate. Pistil included, glabrous; disc annular; ovary ellipsoid, c. 1 by $1 \mathrm{~mm}$, unilocular, dark brown, rough; style c. $4 \mathrm{~mm}$ long; stigma bilobed, $<1 \mathrm{~mm}$ diam., lobes cordiform. Fruiting calyx loosely clasping utricle; all sepals accrescent, broadly elliptic-ovate to suborbicular, 3 outer $14-19$ by $10-19 \mathrm{~mm}, 2$ inner $14-16$ by $8-16 \mathrm{~mm}$, tan to pale brown, outside sparsely appressed pubescent (or glabrate), inside glabrous; veins 5 . Utricle obovoid, apiculate, $4-5$ by $3-4 \mathrm{~mm}$, stiffly chartaceous to thinly coriaceous, brownish with darker striations, smooth, glabrous. Seed ellipsoid to subglobose, 3-4 by $2 \mathrm{~mm}$, brownish to black-brown; hilum c. $1 \mathrm{~mm}$ diameter. 


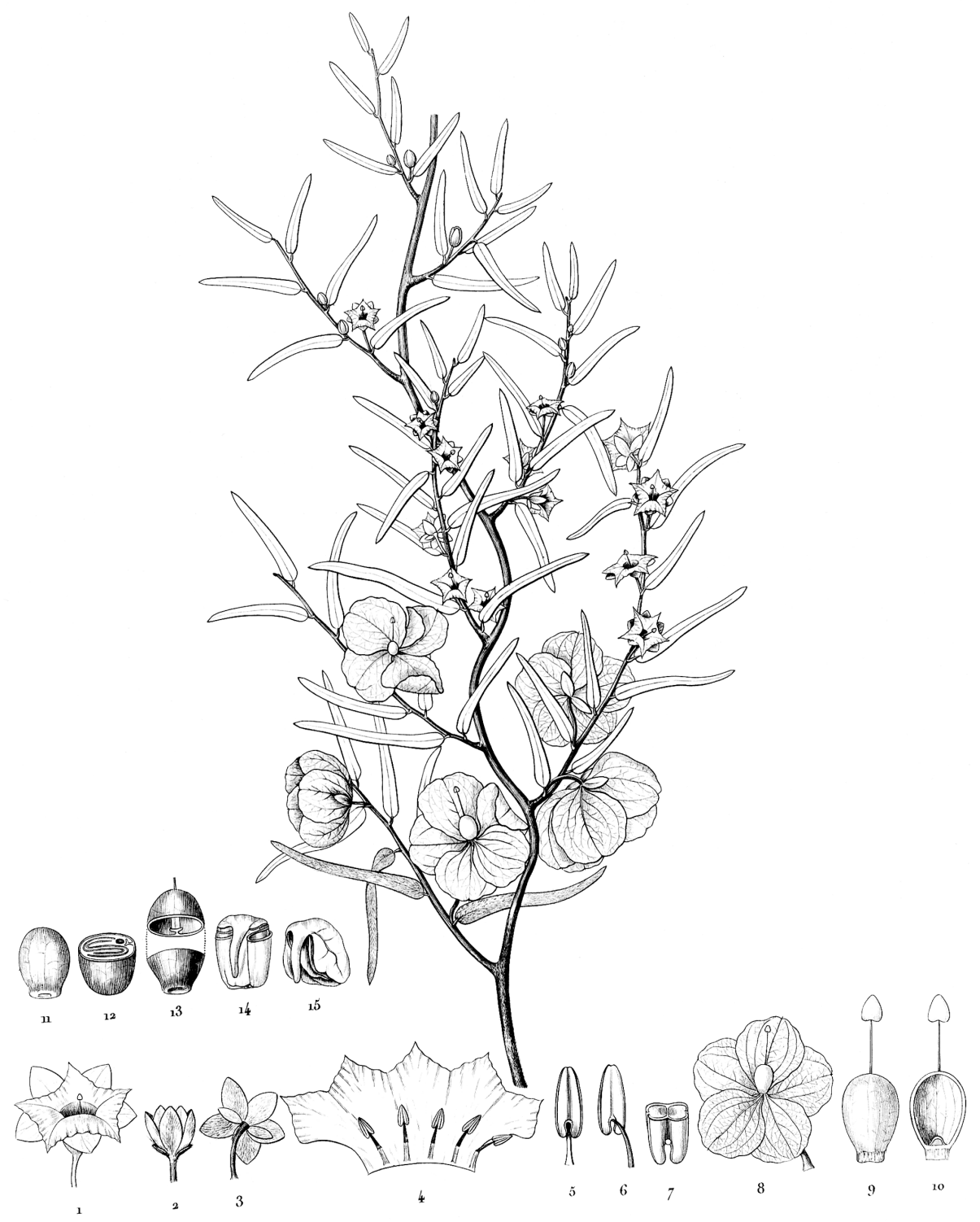

Fig. 11. Duperreya sericea, reproduced from Gaudichaud 1829: t. 63 (original life size). 1. Flower, natural size; 2, 3. calyx and bracteoles; 4. corolla opened; 5, 6. stamens; 7. anther in transverse section; 8 . developed ovary, fruit surmounted by the style and stigma; 9. pistil; 10. ovary in vertical section, inner surface of wall, the base protuberant; 11. ovule, concavity at the base; 12 . ovule in transverse section; 13. the same figure, type of lateral placentation near which the radicle was found to be placed; 14, 15. embryo with deflexed radicle, and folded and crumpled cotyledons. [Legends translated from original French.] 
Distribution - Australia (Western Australia).

Habitat - Deserts including Hakea-Acacia bush, open heath, Triodia-Acacia steppe, on rocky slopes climbing Casuarina dielsiana, and in Acacia (Wanya) scrub. Recorded from red sands and granitic soil (once); in creek beds and on hilltops among lateritic boulders. No elevation data reported on specimen labels.

Phenology - Flowering: July (2), August (4), September (6), October (2). Fruiting: March (1), September (2), October (2).

Typification - The holotype sheet of Ipomoea modesta is at MEL. A sheet at Kew so-labelled has three collections mounted together. The collection on the left side of the sheet is labelled "Murchison River" and is inscribed Ipomoea modesta F. Muell., which agrees with the holotype sheet at Melbourne. Therefore only this fragment on the Kew sheet is recognized as isotype material for I. modesta.

The Gaudichaud specimen in $\mathrm{P}$ is taken to be the holotype for D. sericea. The notation on that sheet at lower right "tab. 60" is an error; that at lower left "t. 63" correctly corresponds to the plate cited in the protologue.

Notes - Duperreya sericea may be recognized by the following combination of characters: the broadly ovate, elliptic to broadly elliptic sepals, widest near the middle; the calyx completely covering the lower corolla; the biglobose stigma with the two lobes more or less cordiform in shape and deflexed downward along the style; the fruiting sepals subcircular or broadly elliptic-ovate. Dried material of this species has a golden aspect due to the yellowish colour of the indumentum.

Study of living plants grown in cultivation shows that the style elongates during anthesis. Initially, when the flowers open in the morning, the pistil is shorter than the androecium, but during the course of the day the pistil elongates so that by day's end it equals the stamens in length. This developmental pattern, plus the fact that the anthers dehisce in bud, suggests that $D$. sericea, like many Convolvulaceae, is protandrous.

\section{PORANA}

Porana Burm.f. (1768) 51. - Type: Porana volubilis Burm.f.

Subglabrous lianas. Roots fibrous. Leaf petiole sulcate, blade simple, entire, chartaceous; venation pinnate, veins prominent abaxially. Inflorescence thyrsiform: an axillary (or terminal), bracteose, compound panicle; bracts foliaceous and petiolate, diminishing distally and becoming sessile; bracteoles 2, scale-like, borne at peduncle/pedicel junction; anthesis proceeding acropetally. Flowers erect, small, fragrant. Sepals 5, free, quincuncial, outer ones half as long as corolla, equally or unequally accrescent in fruit. Corolla campanulate or broadly funnelform-campanulate, 5-lobed, lobes plicate and valvate (not twisted), interplicae hairy outside, plicae diaphanous, glabrous. Stamens 5 , unequal, longest 2 or 3 exserted, filaments fused below to corolla tube, free above, glabrous; anthers ellipsoid, longitudinally dehiscing prior to anthesis; pollen 3-colpate, nonspinose. Pistil exserted; disc annular; ovary unilocular or incompletely bilocular; ovules 4, basal, erect; style terminal, unequally 2-branched; stigmas 2, reniform. Fruiting calyx chartaceous, all 5 sepals equally enlarged or outer 3 larger than inner 2, venation parallel, with 7 or 9 longitudinal veins, forming a subapical reticulum, veins 
\pm prominulous. Utricle chartaceous, 1 suture visible, breaking irregularly or tardily splitting along suture in acropetal direction. Seed 1 (rarely 2), scurfy at first, smooth later, glabrous; hilum basal, C-shaped.

As defined here, Porana consists of just two species, one from Southeast Asia and Malesia, and the other from Mexico ${ }^{1}$. The morphological characters diagnostic for Porana are: lenticellate stems; pinnate leaf venation; a large calyx that covers much of the corolla; a campanulate or broadly funnelform-campanulate corolla; a 2-branched style; fruiting calyx with outer 3 or all 5 sepals \pm equally enlarged; and the looping, weakly developed longitudinal veins of the fruiting sepals. Recent molecular studies support this generic concept (Stefanovic et al., 2002).

The generic concept adopted for Porana in this revision is the narrowest since the late eighteenth century. Wight (1843) recognized that the generic concept of Porana, based on $P$. volubilis, was very close to that for Bonamia Thouars, due principally to similarities in vegetative and floral characters. However, Myint \& Ward (1968) made no mention of the similarities between $P$. volubilis and Bonamia in their revision of the latter genus. The fruits, long thought to be diagnostic (septicidal capsules in Bonamia and indehiscent or irregularly fragmenting utricles in Porana) are not so distinctive as once thought. Field observation of some Mexican Bonamia spp. revealed that their fruits break open irregularly (A. McDonald, pers. comm. 1987). And the suture in the fruit of $P$. volubilis sometimes first splits apart near the base and the fruit later shatters irregularly. The accrescent calyx of Porana immediately sets this genus apart from Bonamia, which has persistent but nonaccrescent calyces. Clearly the relationship between Porana s.s., and Bonamia bears further investigation.

\section{Porana volubilis Burm.f. - Map 10}

Porana volubilis Burm.f. (1768) 51, t. 21*, f. 1. - Type: sine collector, “Herb. Burman 2087” (neotype G), locality unknown.

Porana volubilis Burm.f. var. burmanniana Blume (1826) 723. - Type: Zippelius 91 (lectotype (here designated): L sheet 901.184-360), Timor.

Porana volubilis Burm.f. var. microcarpa Engl. (1886) 472. - Type: Naumann s.n. (holotype not found at B, presumed destroyed), Timor.

Liane 6-10(-20) m long, innovations sparsely golden velutinous. Mature stem woody, to $4 \mathrm{~cm}$ diam., bark brown, coarsely wrinkled, ridged to verrucose, glabrate; younger stems flexuous, 2-5 mm diam., greyish brown, dotted with whitish, elliptic to fusiform lenticels, tips weakly twining. Indumentum on axial parts, along veins on laminar parts, calyx, and corolla of simple, curved, appressed, hairs. Leaf petiole $1.3-2.7(-3.8) \mathrm{cm}$ long, base slightly pulvinate, \pm velutinous within groove; blade ovate, ovate-elliptic, or rarely suborbicular, $5.8-10.7$ by $3.7-6.3 \mathrm{~cm}$, base truncate, emarginate or shallowly cordate, margins sometimes undulate when dry, apex acuminate or caudate, mucronulate, adaxially olivaceous to reddish brown, glossy, glabrous, abaxially paler, more opaque, glabrous or sparsely velutinous along veins; midvein sunken and sparsely velutinous

1) Porana nutans (Choisy) O'Donell (1960) 62. - Ipomoea nutans Sessé \& Moç. ex Choisy (1845) 368. - Calycobolus nutans (Sessé \& Moç. ex Choisy) D.F. Austin (1971) 244. - Type: unpublished Sessé \& Moçiño plate of Trivolvulus nutans (lectotype chosen here, G). 
adaxially, secondary veins ( 5 or) 6 or 7 (or 8) pairs, veins darker than blade. Inflorescence ascending, $12.5-26 \mathrm{~cm}$ long; lower bracts \pm persisting, blade ovate, $2.4-4.7$ by $1.5-3.2 \mathrm{~cm}$; upper bracts smaller, becoming (sub) sessile, deciduous, blade 9-15(-21) by 4-9(-11) $\mathrm{mm}$; bracteoles triangular or subulate, 2-4 mm long, deciduous; pedicels filiform, 3-5 mm long, to 5-9 $\mathrm{mm}$ in fruit; buds obovoid, basally \pm angular, apically obtuse or rounded, sparsely sericeous. Calyx loosely clasping corolla tube; sepals equal, outer 2 elliptic-ovate, $4-5$ by $1-2 \mathrm{~mm}$, inner 3 elliptic, $4-5$ by $<1-1.5 \mathrm{~mm}$, base truncate, margins entire, apex rounded to obtuse, herbaceous and pale green in life, chartaceous and brownish when dry, sparsely puberulent outside, glabrous inside, longitudinal veins several, indistinct, darker. Corolla $7-8$ by $7-8 \mathrm{~mm}$, membranous, white, limb lobes acute, margins hyaline, outside sparsely golden puberulent, inside glabrous. Stamen filaments 4-5 mm long; anthers c. $1 \mathrm{~mm}$ long, introrse, white; pollen oblate (or prolate) spheroidal, $19-28$ by $18-27 \mu \mathrm{m}$, surface psilate. Pistil 7-8 mm long; disc glossy orange; ovary broadly ovoid, slightly 4-lobed, $\leq 1 \mathrm{~mm}$ tall, glossy green dotted brown, apically sericeous; style 3-5 mm long, whitish, sericeous basally, glabrous above; stigmas $<1 \mathrm{~mm}$ diam., white. Fruiting calyx reflexed at maturity, all sepals equally enlarged, elliptic to narrowly obovate or spathulate, 7-9(-11) by $3-4.5 \mathrm{~mm}$, slightly concave, base shortly keeled, distally thin, scarious, stramineous to tan, glabrous; veins \pm parallel, 9 at base, 3 reaching apex. Utricle globose, depressed globose or ovoid, sometimes faintly lobed, 2-4 mm diam., apiculate, stiffly chartaceous, stramineous to dark brown, glossy or opaque, glabrous or sparsely sericeous apically. Seed globose or faintly 2- or 3-lobed, 1.5-3 mm diam., dark brown to black; hilum $<1 \mathrm{~mm}$ diameter.

Distribution - Probably native in Thailand, Laos, Cambodia, Vietnam, Malaysia, and Indonesia; seemingly introduced and naturalized in southern India, Myanmar, and the Philippines.

Habitat - Coastal forests, monsoon forests, thickets, savannahs, along riverbanks and on rocks, and in many situations near human habitations. Soil types reported to be sand, rocky, and 'terre rouge riche'; from sea level to $500 \mathrm{~m}$ (exceptionally to 750 or $1000 \mathrm{~m}$ ) elevation.

Phenology-By geographic region:

Continental Asia, including Peninsular Malaysia and Singapore - Flowering: January (7), February (1), March (3), June (1), September (1), October (8), November (19), December (7). Fruiting: January (2), February (1), March (2), June (2), October (1), November (3), December (2).

Insular Malaysia, Indonesia, Philippines - Flowering: January (1), February (5), March (2), April (5), May (8), June (3), July (5), August (4), September (1), October (1), November (3), December (2). Fruiting: January (1), April (1), May (2), June (1), July (2), August (5), October (1), November (4), December (5).

Vernacular names - Bridal creeper (India, Malaysia, English); saung daw pu (Myanmar); ladaa, ladaawan, maliwan (C Thailand); kalaa phueak (N Thailand); mok-han-sen (N Thailand, Shan dialect); nada (N Thailand, Lao dialect); dây bìm bìm núi (Vietnam, Annamite dialect); mac lôi, uu muôa (Vietnam, Möi dialect); widosarie, widosari, wedosari (Indonesia, Java); plilitan (Indonesia, Soebah); lapat (Indonesia, akar, Idahan); domag-ac, bevoio al Paro (Philippines); German vine (Philippines, English). Additional vernacular names are cited by Van Ooststroom (1938: 90). 


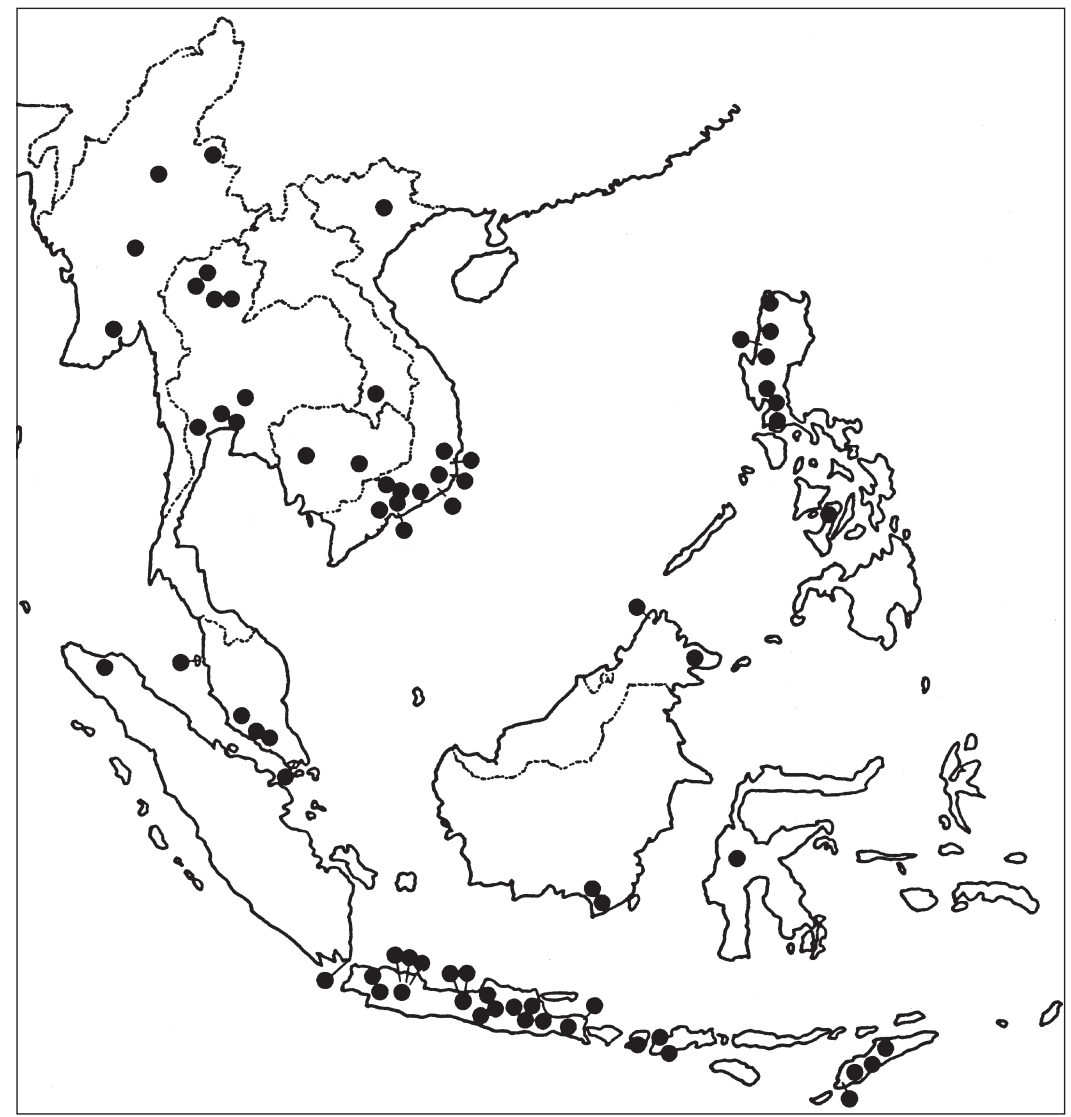

Map 10. Distribution of Porana volubilis Burm.f. in south-eastern Asia and Malesia.

Typification - The types of Burman's 'Flora indica' are mostly in the Delessert herbarium at Geneva, with some duplicates at Munich (Merrill, 1921). Curiously, of the Flora indica Convolvulaceae described by Burman f., all the original material identifiable as potential type specimens were located in $\mathrm{G}$ except for that of $P$. volubilis (Staples \& Jacquemoud, 2005). One sheet of $P$. volubilis at Geneva is labelled "Herb. Burman 2087." It has no locality [Java] or collector [Kleinhof or Kleynhoff] corresponding to the protologue, and thus it cannot be considered original material for the name. Yet the sheet has a brief Latin diagnosis and the words novum genus written on it in Burman's minute handwriting (confirmed by D.O. Wijnands, pers. comm. 1987). This sheet was clearly a specimen Burman studied and it has been chosen as the neotype of $P$. volubilis.

Notes - The following characters are diagnostic for $P$. volubilis: prominently lenticellate stems; pinnate leaf venation; calyx about half as long as the corolla; fully or partly 2-locular ovary; 2-branched style; reniform stigmas; and the fruiting sepals only slightly accrescent relative to their size at flowering. Additional, more subjective 
characters are the weakly twining or scrambling habit, and the (often) grooved or lobed seeds.

This species enjoys localized use in folk medicine. In Vietnam "racines à faire des médicaments" (ex label Phung v. Dien 300). Van Ooststroom (1938: 90) and Perry (1980: 108) cite the use in Indonesia of the fresh leaves as one ingredient in the tonic djamboe bagolan, chewed to freshen the mouth, and in the preparation of a decoction given to women following childbirth.

Porana volubilis is grown widely in Asia as an ornamental. In Myanmar, women wear the flowers in the hair and the inflorescences are sold for that purpose in the market (ex label O.E. White 123). The flowers are esteemed for their delicate fragrance.

\section{PORANOPSIS - Fig. 12}

Poranopsis Roberty (1952) 27. - Type: Poranopsis paniculata (Roxb.) Roberty.

Lianas, lower stem woody, glabrescent, the branches and stem tips herbaceous, tawny or greyish villous or sericeous with 2-armed hairs. Roots fibrous. Leaf petiole terete or flattish, slightly pulvinate; blade cordate-ovate, chartaceous, often rugulose and moderately pubescent adaxially, densely pubescent abaxially; venation pedate. Inflorescence axillary (or terminal), bracteose, paniculate, flowers fascicled at nodes; bracts foliaceous, texture, indumentum and venation like the leaves, bracteoles 2 , scale-like, attached just below calyx. Flowers small, numerous, often fragrant; sepals 5, free, quincuncial, clasping corolla tube base, unequally accrescent in fruit. Corolla funnelform or campanulate-funnelform, limb 5-lobed, lobes plicate (but not twisted) in bud. Stamens 5, filaments basally adnate to corolla tube, free and filiform above; anthers ellipsoidal, $<1 \mathrm{~mm}$ long, longitudinally dehiscent; pollen 3-colpate, nonspinose. Pistil included; disc annular or absent; ovary unilocular; ovules 4, basal, erect; style simple or absent; stigma terminal, biglobose. Fruiting calyx enclosing or partially reflexed from utricle, outer 3 sepals greatly enlarged, ovate or subcircular, margins free or partially adherent basally, inner 2 sepals only slightly enlarged, often falcate; sepals all thinly chartaceous, midvein 1 , finer veins reticulate, prominulous, darker. Utricle globose to ellipsoid, often apiculate by persistent style, chartaceous, smooth or slightly wrinkled, glabrous or puberulent. Seed 1, reddish brown to black, smooth, glabrous; hilum (semi-)circular.

A genus of three species, ranging across the Indian subcontinent to southwestern China and throughout Southeast Asia.

Typification - Roberty (1952) diagnosed his new genus Poranopsis as follows "Poranineae, corolla subintegra, profunde infundibuliforme, minima vel maxima". He included two taxa in it, $P$. paniculata (Roxb.) Roberty and P. spectabilis (Kurz) Roberty, placing Porana megalantha Merr. in synonymy with the latter species. Later, Roberty (1964) typified the genus, selecting $P$. paniculata as the type species. In the generic concept adopted here, I include only the small-flowered plants, excluding the large-flowered species to the genus Tridynamia.

Notes - The characters diagnostic for Poranopsis are: the lianoid habit; densely velvety pubescent leaves; small funnelform corolla; unequally accrescent fruiting calyx with the outer 3 sepals much enlarged, ovate or suborbicular, and the inner 2 only slightly enlarged; the fruit sepals with a single midvein and a reticulum of secondary veins. 

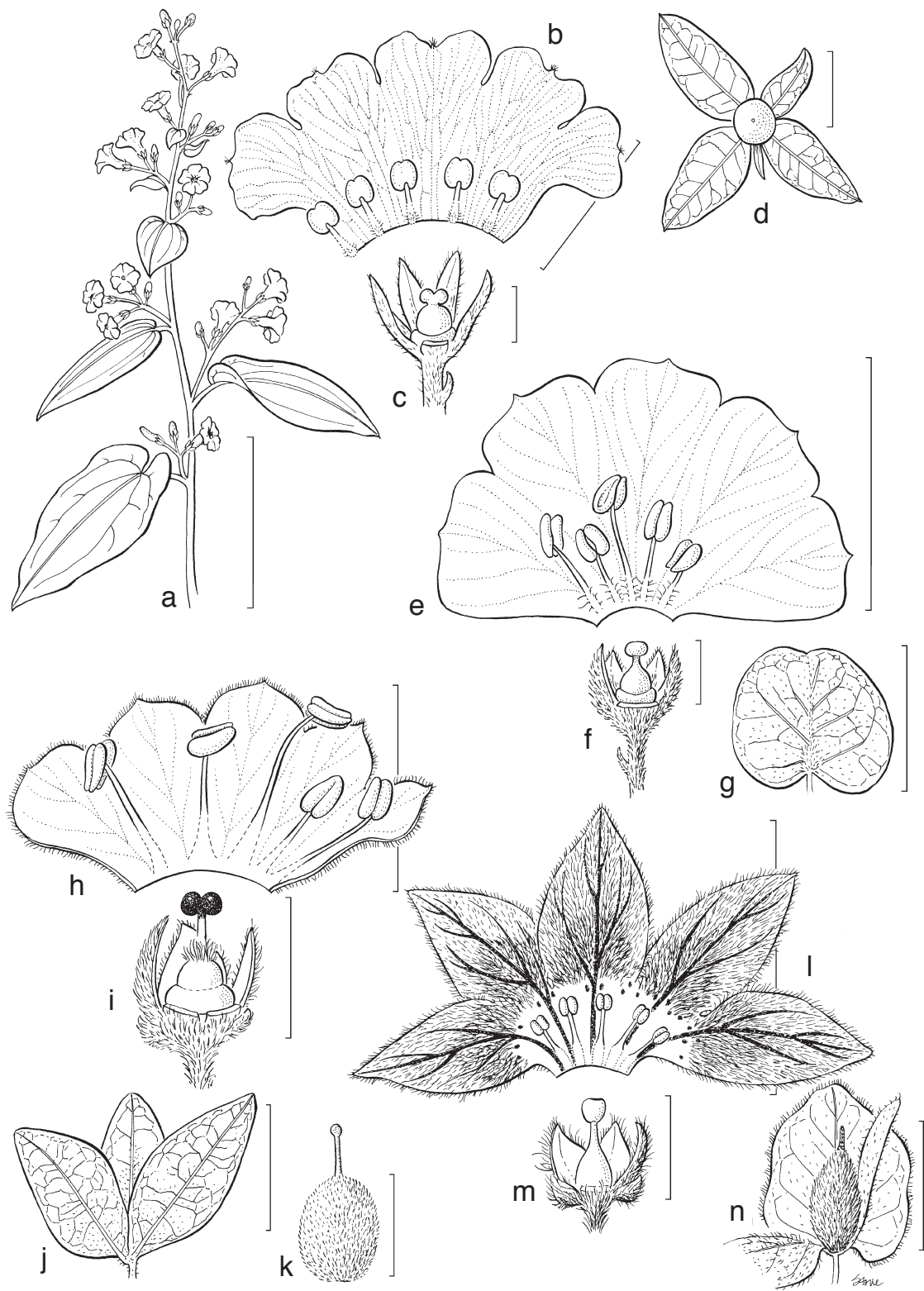

Fig. 12. Poranopsis and Cordisepalum species. a-d: Poranopsis paniculata. a. Flowering stem habit; b. corolla opened; c. calyx (1 sepal removed), gynoecium, and bracteole; d. fruiting calyx and utricle. - e-g: P. sinensis. e. Corolla opened; f. calyx (1 sepal removed), gynoecium, and bracteole; g. fruiting calyx. $-\mathrm{h}-\mathrm{k}$ : P. discifera. h. Corolla opened; i. calyx (2 sepals removed), gynoecium, and bracteoles; j. fruiting calyx; k. gynoecium. - 1-n: Cordisepalum thorelii. l. Corolla opened; m. calyx ( 2 sepals removed), gynoecium, and bracteoles; $n$. fruiting calyx and utricle (a-c: drawn from living plant; d: Koeltz 4273; e-g: Henry 9489; h-k: Poilane 26707; 1-n: Chevalier 30976). Scale bars: $\mathrm{a}=5 \mathrm{~cm} ; \mathrm{b}, \mathrm{e}, \mathrm{l}=5 \mathrm{~mm} ; \mathrm{c}, \mathrm{f}=1 \mathrm{~mm} ; \mathrm{d}, \mathrm{j}=1 \mathrm{~cm} ; \mathrm{g}=1.6 \mathrm{~cm} ; \mathrm{h}=3 \mathrm{~mm} ; \mathrm{i}, \mathrm{m}=2 \mathrm{~mm}$; $\mathrm{k}=4 \mathrm{~mm} ; \mathrm{n}=8 \mathrm{~mm}$. 
The three species are very similar and it is essential to have fertile material to differentiate between them; vegetatively they are indistinguishable. Geographic provenance is helpful, at least narrowing the choice to two of the three possibilities.

\section{KEY TO THE SPECIES}

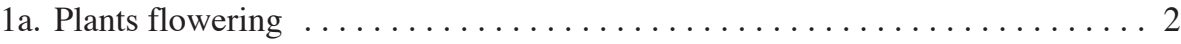

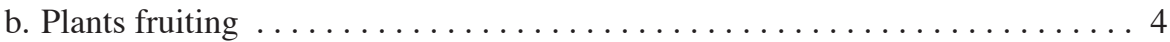

2a. Style very short, stigma subsessile; stamens \pm equal $\ldots \ldots \ldots$ 15. P. paniculata

b. Style length $\geq$ ovary; stamens unequal in length . . . . . . . . . . . 3

3a. Longest stamens exserted from the corolla throat $\ldots \ldots \ldots \ldots$ 14. P. discifera

b. Longest stamens included within corolla throat . . . . . . . 16. P. sinensis

4a. Sepals cordate to suborbicular; utricle glabrous . . . . . . . . . 16. P. sinensis

b. Sepals ovate to elliptic-oblong; utricle puberulent $\ldots \ldots \ldots \ldots \ldots \ldots \ldots 5$

5a. Sepals \pm shiny and glabrous on the inner face; utricle trichomes simple and sep-

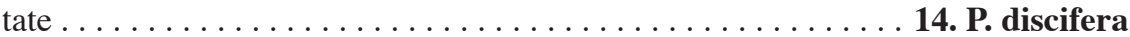

b. Sepals opaque and puberulent on the inner face; utricle trichomes 2 -armed ....

15. P. paniculata

\section{Poranopsis discifera (C.K. Schneid.) Staples - Fig. 12h-k; Map 11}

Poranopsis discifera (C.K. Schneid.) Staples (1993) 200. - Porana discifera C.K. Schneid. (1916) 358. - Cardiochlamys discifera (C.K. Schneid.) C. Y. Wu in Wu \& Li (1965) 106. - Type: A. Henry 12694 (holo A; iso A, K, MO, NY, fragment W), China.

Porana henryi auct. non Cardiochlamys sinensis Hand.-Mazz. (1920): Verdc., p.p. (1971) 137, quoad Forrest 13591, Anderson \& Smitinand 7219.

Lianas to $10 \mathrm{~m}$ long, vegetative parts tawny to ferruginous. Mature stem brownish, striate or wrinkled, solid; younger stems terete, smooth, 3-5 mm diam., appressed pubescent, fistulose when dry. Indumentum arms usually appressed. Leaf petiole 2.1-5 cm long; blade broadly ovate-cordate to nearly orbicular, $5.8-13$ by $4-10.5$ $\mathrm{cm}$, base cordate, apex acuminate, adaxially darker sericeous to glabrate, abaxially densely villous; venation with 3 or 4 basal pairs and 2 (or 3) distal pairs of secondary veins. Inflorescence congested, to $36 \mathrm{~cm}$ long; bracts foliose; lower bracts petiolate, petiole (5-)13-16(-23) $\mathrm{mm}$ long, blade ovate, $3.7-6.3$ by $2.5-4.3 \mathrm{~cm}$, base cordate, apex acute to acuminate; upper bracts subsessile, lanceolate to linear, (0.5-)1-3.3 by $0.4-1.8 \mathrm{~cm}$; pedicels filiform, $3-5 \mathrm{~mm}$ long, increasing to $9 \mathrm{~mm}$ in fruit. Flowers slightly fragrant; buds ellipsoid, obtuse to rounded, to $5 \mathrm{~mm}$ long, villous. Sepals \pm equal, $1-1.5$ by $<1 \mathrm{~mm}$, outer 3 lanceolate to narrowly ovate, inner 2 lanceolate to falcate, all 5 flat medially keeled or \pm naviculate, base truncate, margins entire, apex acute to acuminate, chartaceous, villous outside, glabrous inside. Corolla $3-5$ by $3-5$ $\mathrm{mm}$, membranous, white or cream-coloured, outside tube base glabrous, upper tube and interplical areas tawny villous, plicae glabrous, inside entirely glabrous. Stamens unequal, 3 exserted, 2 included; filaments 3-5 mm long, sparsely pubescent below with crinkled hairs, glabrous above; anthers introrse, whitish; pollen oblate to prolate spheroidal, $11-13$ by $12-15 \mu \mathrm{m}$, surface psilate to finely granulate, pilate-multiangulate inside colpi. Pistil 1.5-2 mm long, just exceeding to twice as long as calyx; disc 
annular, c. twice diameter of ovary, black when dry, glabrous; ovary ovoid, apically or entirely rusty velutinous; style present; stigma biglobose, black when dry. Fruiting calyx spreading; outer 3 sepals ovate-oblong to elliptic-oblong, 15-22 by 7-13 mm, base truncate to shallowly cordate, margins entire, free, apex obtuse, acute, or acuminate, often mucronulate, inner 2 linear to oblanceolate, \pm falcate, $3-11$ by $1-4 \mathrm{~mm}$; sepals all pale tan to brownish, translucent with age, abaxial surface \pm puberulent, opaque, adaxial surface subglabrous, shiny. Utricle globose to broadly obovoid, flaring above disc, apiculate, $4-6(-8)$ by $3-5 \mathrm{~mm}$, dark brown, smooth, tawny pilose with erect, multicellular, simple hairs. Seed spherical, c. $3 \mathrm{~mm}$ diam., glabrous or tawny puberulent at first, glabrate; hilum c. $1 \mathrm{~mm}$ diameter.

Distribution - NE India, N Myanmar, SW China, N Thailand, and Vietnam; probably also in Laos, but no collections seen from there.

Habitat - Open situations in evergreen forests, scrub jungles, thickets, along riverbanks and roadsides and at the margin of cultivated areas. Often on rich, calcareous soils; at 380-1800 m elevation.

Phenology - Flowering: January (1), March (1), September (1), October (6), November (14), December (15). Fruiting: January (5), February (2), April (1), December (4).

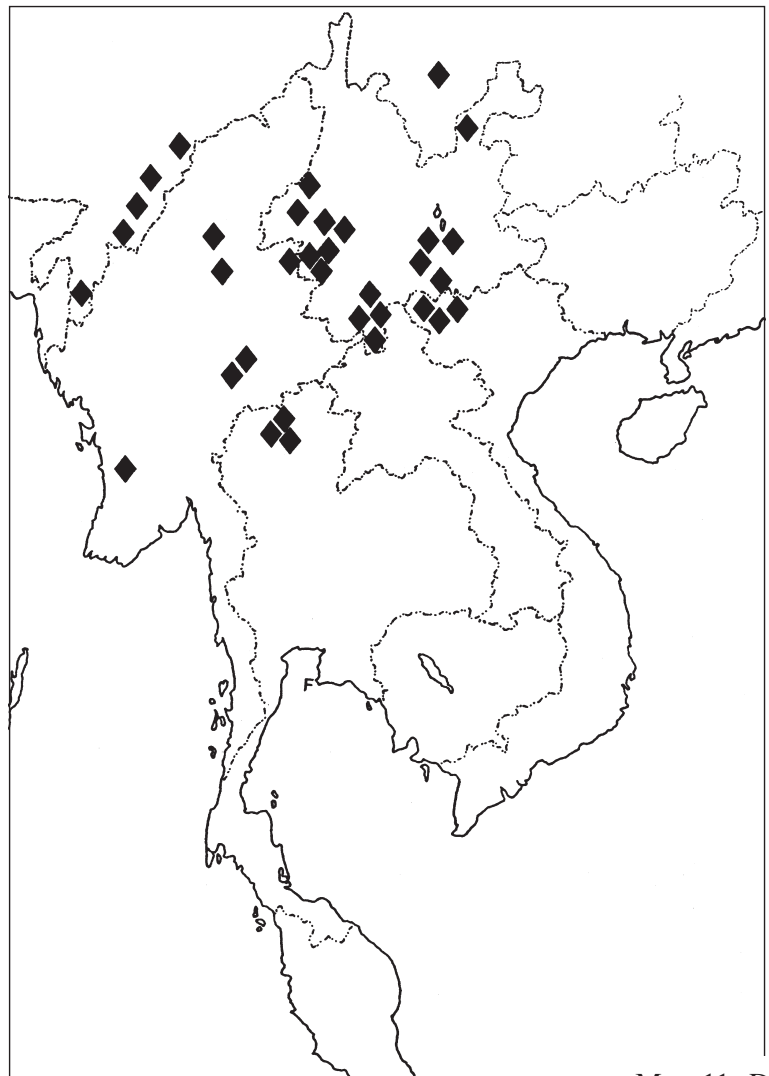

Map 11. Distribution of Poranopsis discifera (C.K. Schneid.) Staples in south-eastern Asia. 
Vernacular names - M'ma (Vietnam, Meo dialect); da peng teng (China).

Notes - Poranopsis discifera may be recognized by the following characters: ovate sepals covering the base of the corolla tube; the pistil longer than the calyx; a prominent cushion-like disc; an ovary that is apically or entirely rusty velutinous; 3 stamens exserted from the corolla; fruiting sepals that are slightly shiny and (sub)glabrous on the inner surface; and utricles puberulent with simple, glandular multicellular hairs (Fig. 2c, d). The indumentum of this species is often rusty or reddish brown, and the leaves are distinctly darker coloured adaxially, due to a lower density of trichomes on that side.

Poranopsis discifera is closely related to, and readily confused with, P. paniculata. The characters that separate them are constant, though the floral characters are difficult to observe due to the small size of the flowers. In addition, their ranges overlap only slightly and the geographic origin of a specimen is often a clue to its identity. They would seem to be a pair of closely related, allopatric species.

Poranopsis discifera is also similar to P. sinensis; it is distinguishable from that species by its spreading ovate-oblong fruiting sepals with acute apices, free margins, and truncate, rounded or shallowly cordate bases, and puberulent utricles. Flowers of these two taxa are much alike, but the 2 longest stamens of $P$. sinensis just reach the corolla throat without being exserted as in $P$. discifera. In addition, the leaves of $P$. discifera are usually darker adaxially, due to their lower indumentum density, and the panicles are comparatively more congested with shorter internode length and more flowers per node.

\section{Poranopsis paniculata (Roxb.) Roberty - Fig. 12a-d; Map 12}

Poranopsis paniculata (Roxb.) Roberty (1952) 26. - Porana paniculata Roxb. (1819) 31, t. 235. - Dinetus paniculatus (Roxb.) Sweet (1827) 289. - Type: Roxburgh s.n. sub Wallich Catalogue $1325 E$ (lectotype (chosen here) K-W; probable isolectotypes BR, OXF), India, Calcutta Botanic Garden.

Porana tomentosa Lesch. ex Choisy (1834) 489, nomen pro syn., invalid under Article 34.

Liana to $15 \mathrm{~m}$ long, vegetative parts greyish to tawny. Mature stems cylindrical, spirally striate, 2.5(-5) cm diam., tan to greyish brown; branches often pendulous, younger stems terete, 3-6 mm diam., smooth or striate, shoot tips puberulent, pith solid. Indumentum arms appressed or erect. Leaf petiole 2.6-10.8 cm long, 2-3 mm diam.; blade cordate or broadly ovate-orbicular, $7.5-16.5$ by $5.3-15 \mathrm{~cm}$, base cordate, apex acute to acuminate, sometimes apiculate, adaxially subglabrous or scabridulous with appressed hairs, abaxially greyish to silvery villous, denser along veins, venation with 2 or 3 (or 4) basal pairs and 1 (or 2) distal pairs of secondary veins. Inflorescence horizontal or ascending, 33-62 cm long, lower bracts foliose, petiolate, petiole 7-30 mm long, blade cordate, $3.1-7.7$ by $1.8-5.5 \mathrm{~cm}$, sometimes apiculate; upper bracts becoming (sub) sessile, cordate-ovate (to linear-subulate), (5-10-)15-28 by (1-2-)6-14 $\mathrm{mm}$; pedicels filiform, 2-4 mm long, elongating slightly in fruit. Flowers sweetly fragrant; buds ellipsoid to obovoid, apically obtuse, villous. Sepals equal, lanceolate to linear, flat or slightly naviculate, 1-2 mm long, base truncate, margins entire, apex tapering acuminate, chartaceous, tomentose-villous outside, glabrous inside. Corolla narrowly funnelform, (4-)5-6(-7) by (3-4-)5-7 mm, membranous, white to cream coloured, tube slender, throat flaring abruptly, limb shallowly 5-lobed, lobes obovate, retuse, 
\pm mucronulate, outside of tube and plicae glabrous, throat and interplical areas villous, inside completely glabrous. Stamens subequal, $\leq 2 \mathrm{~mm}$ long, included; filaments glabrous; anthers extrorse, whitish; pollen 3-colpate, prolate to obtuse-rectangular, 13-14 by $9-10 \mu \mathrm{m}$, surface psilate. Pistil $\leq 0.5 \mathrm{~mm}$, included in corolla tube; disc absent, or small, annular, and brown; ovary subglobose to broadly ovoid, brownish, glabrous; style very short; stigma subsessile, biglobose, lobes spherical, erect. Fruiting calyx loosely clasping to diverging from utricle, outer 3 sepals elliptic-oblong to narrowly ovate, $16-22(-24)$ by $7-9 \mathrm{~mm}$, base obtuse to truncate, margins entire, free, apex rounded, obtuse (or retuse), often mucronulate; inner 2 sepals linear to falcate, $(4-5-) 6-7(-9)$ by $(<1-) 2-3 \mathrm{~mm}$; all sepals chartaceous, tan, reddish or pale brown, bifacially puberulent, opaque. Utricle globose to broadly ellipsoid, apiculate, $5-6(-7)$ by $4-5 \mathrm{~mm}$, chartaceous, tan to brownish, darker striate, pubescent with erect, 2-armed hairs. Seed globose to broadly ellipsoid, $4-6$ by $3-5 \mathrm{~mm}$, dark brown, faintly striate, glabrous; hilum basal, c. $1 \mathrm{~mm}$ diameter. Chromosome number 2n = 26 (Manitz, 1983).

Distribution - South of the Himalayas in Pakistan, India, Nepal, Bhutan, Tibet, Bangladesh, and Myanmar.

Phenology — Flowering: January (9), February (5), March (2), April (1), September (2), October (20), November (40), December (15). Fruiting: January (2), February (3), March (8), April (5), November (1).

Habitat - Forests, scrub thickets, subtropical jungles, open plains, and around human habitations. Soil types have been recorded as rocky, stony, conglomerate and limestone (in a subtropical jungle habitat); from sea level to $2000 \mathrm{~m}$ elevation. Widely introduced as an ornamental throughout the tropical regions of the world.

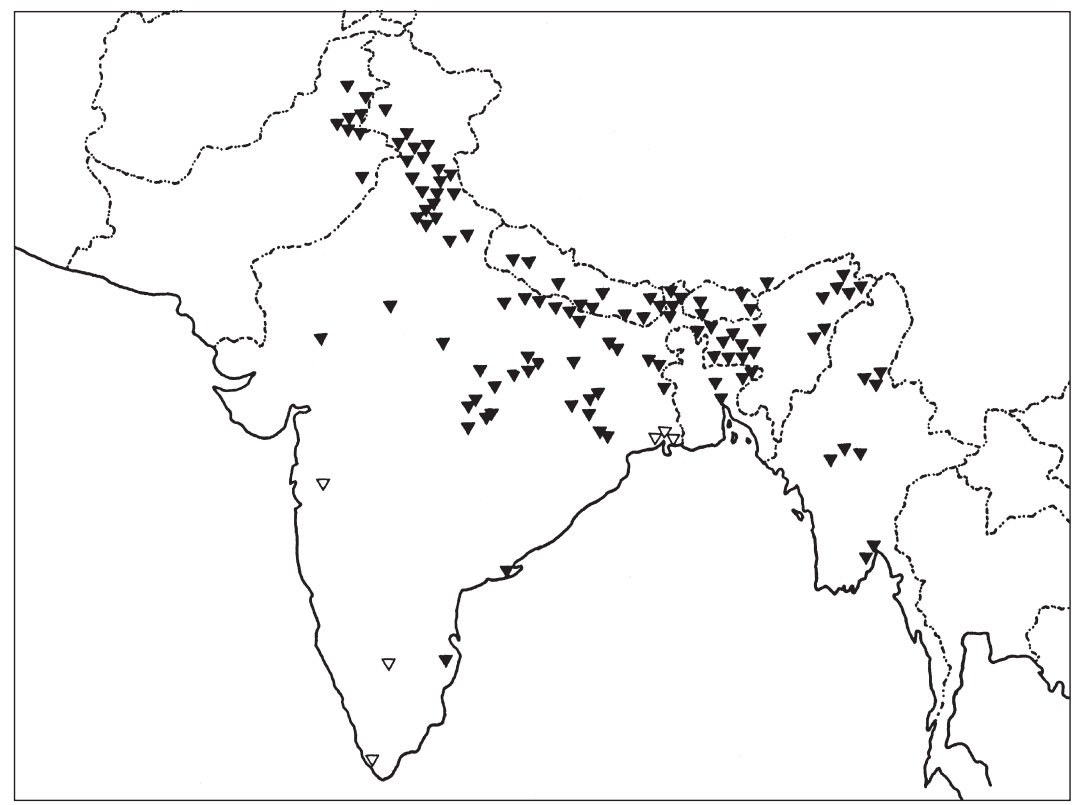

Map 12. Distribution of Poranopsis paniculata (Roxb.) Roberty ( $\boldsymbol{\nabla})$ in the Indian subcontinent; $(\nabla)$ cultivated plants. 
Vernacular names - Faindal, jhol (India, Himachal Pradesh); bel-kámú, bridal wreath, lethai, safed-bel (Uttar Pradesh); jharo, silver creeper (Madhya Pradesh); poranana (Maharashtra); buria-lar, khar (Orissa); silvar creeper (West Bengal); rutaza (Meghalaya, Garo dialect); mahadeo lahara (E Nepal); December pan (Myanmar, Rangoon); thazin pan (Myanmar, Pyinmana); yuan zhui fei e teng (China); bridal creeper (Malaysia, English), schildersverdriet (Dutch), kembang garen (Malay); bridal bouquet (Philippines); bridal veil, Christmas vine, white corallita (USA, Florida); Ipomoea (Mexico, Yucatan); Christmas vine, white coralita (Jamaica); vela de nova (Dominican Republic); coralite, coralline (U.S. Virgin Islands); mugue (St. Barts); Chinese lace (Dutch Antilles); muget, muguet (Guadeloupe); corallila (Grenada); corallete creeper (Sierra Leone); liane de mai (Seychelles Islands).

Typification - The typification of Roxburgh's plant names has long been problematic (Forman, 1997). The late Leonard Forman verified that the specimen of P. paniculata in the East India Company Herbarium at Kew, under Wallich Catalogue number $1325 \mathrm{E}$ is one of Roxburgh's own specimen; the small handwritten label in the upper left corner 'Porana paniculata' is Roxburgh's handwriting. This specimen is here chosen as the lectotype.

Notes - The characters diagnostic for $P$. paniculata are: the narrowly lanceolate sepals that do not fully cover the base of the corolla tube; the pistil shorter than the calyx, with the stigma virtually sessile atop the ovary; the glabrous ovary; the subequal stamens borne low in the corolla tube; the fruiting sepals which are dully opaque and \pm puberulent on the inner surfaces.

It is necessary to clarify one misconception about the floral morphology of P. paniculata and its close relative $P$. discifera. Schneider (1916) named $P$. discifera because of its prominent disc, contrasting it with $P$. paniculata, which he thought always lacked a disc. In fact, some individuals of $P$. paniculata have an annular, tan to brown disc, which is less prominent than that of $P$. discifera, but is still discernible. It is clearly depicted in the plate appearing in 'Curtis's Botanical Magazine' (118: t. 7240. 1892) and in Van Ooststroom's Flora Malesiana treatment (Van Ooststroom \& Hoogland, 1953: 404, f. 10) illustrating Porana paniculata. In contrast, Govil (1972), in studying the vascular anatomy of this species, found the disc absent in the plants he examined.

Two collections from the area of range overlap with P. discifera [W.H. Koelz 27343, S.M. Toppin 4023] exhibit character states intermediate between these two species. The rufous indumentum, sepal shape and apically velutinous ovary are like those of $P$. discifera, while the small disc, pistil shorter than the calyx, and stamens borne within the corolla tube are like those of $P$. paniculata.

Poranopsis paniculata is widely cultivated as an ornamental. The first report of its cultivation dates from 1799, in the botanical garden of the British East India Company at Calcutta. It is now found throughout the tropical regions of the world. However, the large size and expansive habit of the plant limit its popularity with horticulturalists.

\section{Poranopsis sinensis (Hand.-Mazz.) Staples - Fig. 12e-g; Map 13}

Poranopsis sinensis (Hand.-Mazz.) Staples (1993) 200. - Cardiochlamys sinensis Hand.-Mazz. (1920) 241; (1923) 98; (1936) 809; (1938) 125. - Porana henryi Verdc. (1971) 137, nom. nov., non P. sinensis Hemsl. in Forbes \& Hemsley (1890). - Type: Handel-Mazzetti 751 (holo W; iso WU), China.

Porana paniculata auct. non Roxb. (1819): C.K. Schneid. (1916) 359, quoad Henry 9489. 
Liana to several meters long, vegetative parts tawny to rufous brownish. Stem base brownish, glabrate; younger stems terete to subangular, fistulose, densely sericeous. Indumentum of 2-armed hairs, arms equal, appressed, erect, or ascending. Leaf petiole $1.6-4.9 \mathrm{~cm}$ long; blade ovate-cordate, $6.3-9.5$ by $3.6-7.8 \mathrm{~cm}$, base shallowly cordate, apex acuminate or rarely acute, adaxial surface slightly darker coloured; venation with 3 (or 4) basal pairs and 1 (or 2) distal pairs of secondary nerves. Inflorescence lax, 21-36 cm long, internodes long. Lower bracts petiolate, petiole 7-12 mm long, blade cordate-ovate to oblong, $2.5-5.8$ by $1.7-3.8 \mathrm{~cm}$, apically attenuate or acute, apiculate; upper bracts sessile, ovate or elliptic (or scale-like), $(2-) 8-35$ by $(<1-) 4-23 \mathrm{~mm}$; pedicels 3-6 $\mathrm{mm}$ long, increasing to $8 \mathrm{~mm}$ in fruit. Flowers fragrant; buds obovoidclavate, apex rounded, c. $5 \mathrm{~mm}$ long, sericeous. Sepals equal, $1-2$ by $<1 \mathrm{~mm}$, outer 3 broadly ovate, midvein raised, visible, inner 2 linear-filiform to narrowly lanceolate, all bases truncate, margins entire, apices acute or acuminate, densely golden tomentose outside, glabrous inside. Corolla campanulate-funnelform, 4.5-6(-7) by 4-6(-7) $\mathrm{mm}$, membranous, white to creamy, tube broad, outside glabrous below, upper tube and interplical areas tawny sericeous, limb entire to shallowly 5-lobed, lobes mucronate, terminating in abaxial apical tuft of hairs, plicae glabrous, inside of corolla glabrous. Stamens unequal, $\leq 2 \mathrm{~mm}$ long, 2 reaching corolla throat, 3 included in tube; filaments villous below, glabrous above; anthers extrorse, spirally twisted with age, light yellow; pollen 3-colpate, prolate spheroidal, $14-15$ by $10-12 \mu \mathrm{m}$, surface psilate to finely granulate, pilate-multiangulate within colpi. Pistil c. $2 \mathrm{~mm}$ long, included; disc annular or absent; ovary narrowly ovoid-conical, $<1 \mathrm{~mm}$ tall, black when dry, glabrous or sparsely villous apically; style $<1 \mathrm{~mm}$ long; stigma biglobose, lobes horizontal or slightly deflexed. Fruiting calyx bladdery, clasping utricle, third sepal folded back

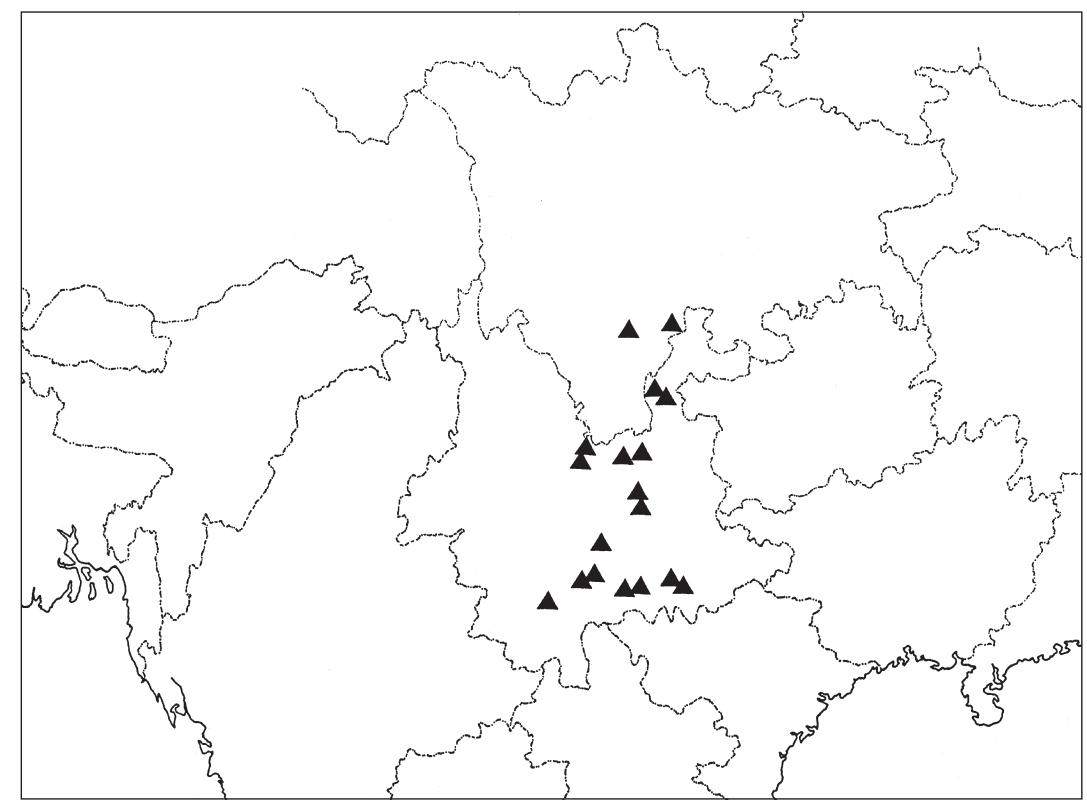

Map 13. Distribution of Poranopsis sinensis (Hand.-Mazz.) Staples in western China. 
on itself lengthwise in dried material; outer 3 sepals ovate-cordate to suborbicular, (1.2-)1.4-1.9 by (1.2-) $1.5-1.7 \mathrm{~cm}$, base shallowly cordate, margins adherent for lower $1 / 3-1 / 2$, free distally, apex obtuse, rounded to emarginate, mucronulate, stiffly chartaceous, tan to pale brown, outside sparsely puberulent, opaque, inside glabrous, shiny; veins purplish brown, prominulous, inner 2 sepals slightly enlarged, filiform, 2-4 $\mathrm{mm}$ long, membranous, puberulent. Utricle ellipsoid or narrowly obovoid, apiculate, $3.5-6$ by $2.5-4 \mathrm{~mm}$, chartaceous, pale tan to dark brownish, darker striate, smooth to slightly wrinkled, glabrous or sparsely apically hairy. Seed ellipsoid, ovoid, or subglobose, $3-4$ by $3 \mathrm{~mm}$, black, red-brown, or dark brown, smooth, glabrous; hilum basal, circular, c. $1 \mathrm{~mm}$ diameter.

Distribution - China (Sichuan, Yunnan).

Habitat - Scrub, covering rock cliffs, on dry slopes, and along riverbanks on calcareous and schistaceous soils. At 350-2000 m elevation.

Phenology - Flowering: October (5), November (5), December (1). Fruiting: February (1), November (4).

Vernacular names - Bai hua ye (China).

Notes - Poranopsis sinensis is recognizable by its possession of the following characters: 2 or 3 stamens reaching the corolla throat, but not exserted from it; the small (or absent) disc; the glabrous or only apically velutinous ovary; the fruiting sepals (Fig. $12 \mathrm{~g}$ ) suborbicular or broadly ovate, with shallowly cordate base and emarginate apex, the margins of the outer 3 sepals adherent for the lower 1/3 to $1 / 2$ of their length; and the glabrous utricles. Additional characters are the comparatively lax inflorescences and more or less uniformly coloured leaves, due to the indumentum density on the upper leaf surface, which masks the dark colour of the lamina proper.

Flowering material of $P$. sinensis is very similar to $P$. discifera. Indeed, Verdcourt (1971) cited specimens of $P$. discifera (Forrest 13591, Anderson \& Smitinand 7219) among those he assigned to Porana henryi (= Poranopsis sinensis). The principal means for distinguishing flowering specimens is the length of the stamens, although the aspect of the leaves and the degree of congestion in the inflorescences is also helpful. The fruiting characters are quite distinctive however, and readily differentiate these species.

The orbicular or broadly ovate fruiting sepals of $P$. sinensis with their cordate base and partially adherent margins, are unique in Poranopsis. Similarly shaped fruiting sepals (with free margins) are typical of the genus Cordisepalum, which is separable from Poranopsis based on its rotate, deeply divided corolla and the elongated stalk that supports the utricle.

\section{TRIDYNAMIA - Fig. 13}

Tridynamia Gagnep. (1950) 26. - Type: Tridynamia eberhardtii Gagnep. (= T. megalantha).

Lianas, lower stem woody, glabrescent, upper branches herbaceous, \pm tomentosevillose. Leaf petiole terete or compressed, sulcate adaxially, pulvinate; blade cordiform, stiffly chartaceous or subcoriaceous, densely pubescent abaxially; venation pedate, secondary veins 2 or 3 basal pairs and 1, 2, or 3 distal pairs, veins prominulous abaxially. Inflorescence axillary (or terminal), bracteose, racemose or paniculate, flowers fascicled (rarely solitary) at nodes, anthesis proceeding acropetally; bracts foliaceous, 


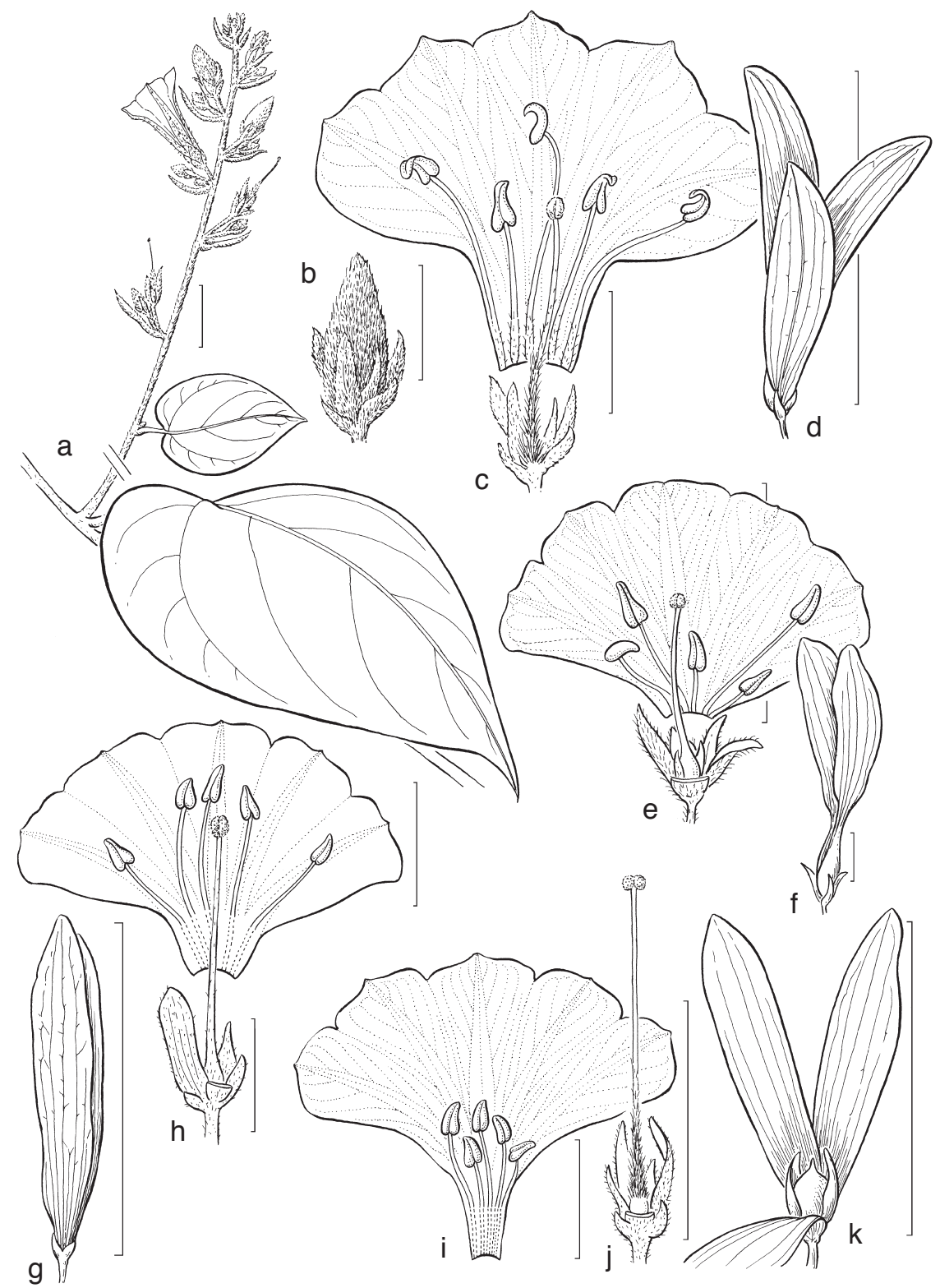

Fig. 13. Tridynamia species. a-d: T. megalantha. a. Flowering stem habit; b. flower bud with calycle; c. flower, corolla opened, showing hairy style base and sagittate anthers; d. fruiting calyx. - e, f: T. bialata. e. Flower, corolla opened; f. fruiting calyx with prominent calycle. $-\mathrm{g}$, h: $T$. sinensis var. sinensis. g. Fruiting calyx; h. flower, corolla opened, 1 sepal removed. $-\mathrm{i}-\mathrm{k}$ : T. spectabilis. i. Corolla opened; j. flowering calyx (1 sepal removed), calycle, and gynoecium; k. fruiting calyx, 1 sepal deflexed to expose utricle (a, d: from photo of Staples \& Wongprasert 140; b, c: Poilane 28095; e: Poilane 3053; f: Put 2326; g: Huang 40898; h: Handel-Mazzetti 10877; i, j Koyama et al. T-49020; k: from photo of Kurz 1083). Scale bars: a-c, e, f, i, j=1 cm; d = $6.5 \mathrm{~cm} ; \mathrm{g}=8.7 \mathrm{~cm}$; $\mathrm{h}=6 \mathrm{~mm} ; \mathrm{k}=5 \mathrm{~cm}$. 
shape, texture, indumentum, and venation like the leaves; bracteoles 3, unequal, attached just below calyx, scale-like or bracteose, persisting in fruit. Flowers small to large, showy, odourless or fragrant. Sepals 5 , free, quincuncial, unequal, clasping corolla tube base, unequally accrescent in fruit. Corolla campanulate to broadly funnelform, limb subentire to 5-lobed, lobes contortuplicate in bud. Stamens 5, filaments in lower half adnate to corolla tube, free and filiform above; anthers sagittate, versatile, dehiscing longitudinally; pollen 3-colpate, nonspinose. Pistil included or exserted; disc 5-lobulate or absent; ovary unilocular; ovules ( 2 or) 4, basal, erect; style simple, glabrous or pubescent below middle; stigma entire or bilobed, wrinkled. Fruiting calyx basally enclosing utricle, flat and slightly flaring above, outer 2 or 3 sepals greatly enlarged, oblong-linear, inner sepals only slightly enlarged, ovate; sepals all chartaceous, veins (7 or) 9 from base, parallel, longitudinal, 3 reaching apex, veins prominulous abaxially. Utricle ovoid, ellipsoid, or obovoid, often apiculate by indurate style base, chartaceous, wrinkled, glabrous or pilose-tomentose. Seed 1, shaped like utricle, reddish brown to black, smooth, glabrous; hilum basal, circular.

A genus of four species, one encompassing two varieties, distributed from northeastern India and the Andaman Islands across south-eastern Asia to southern China and Hainan Island.

The characters diagnostic for Tridynamia are: the suffrutescent habit; 3 sepaloid bracteoles; unequal sepals; showy, campanulate or broadly funnelform corolla; sagittate, versatile anthers; unequally accrescent fruiting calyx with the outer 2 or 3 sepals greatly enlarged, oblong-linear, and the inner sepals only slightly enlarged; fruiting sepals with 7 or 9 parallel longitudinal veins at the base, with 3 reaching the apex. There is remarkable convergence in morphology between Tridynamia, especially T. bialata, and the monospecific Malagasy endemic, Rapona tiliifolia (Stefanovic et al., 2002). Historically considered to be closely related and consequently placed together in the tribe Poraneae, the molecular data suggest that Rapona is distantly related at best. In the latest attempt at a family classification, Rapona is tentatively assigned to tribe Dichondreae, sensu Stefanovic et al. (2003), whereas the same authors place Tridynamia in the new tribe Cardiochlamyeae.

The genus Tridynamia comprises two species pairs. Tridynamia bialata and $T$. sinensis share the features of blue corolla and outer 2 sepals greatly enlarged in fruit; T. megalantha and $T$. spectabilis share the characters of white corolla and the outer 3 sepals greatly enlarged in fruit.

Typification - Gagnepain (1950) named the monotypic genus Tridynamia without a description, basing it on $T$. eberhardtii. He did not conclusively assign the genus to a tribe, noting the similarities and differences with the Convolvuleae, “... bandes longitudinales de la corolle et les autres caractères, mais le stigmate entier ce qui l'en exclut.” and also with the Poraneae, “... qu'il a des sépales très accrescents, mais il ne possède qu'un seul style et qu'un stigmate entier." He went on to comment that the 3 sepaloid bracteoles gave the flower the appearance of having eight sepals rather than the five typical for Convolvulaceae, and that, "... ce qui serait sans exemple dans aucune autre Convolvulacée." by which Gagnepain may have been suggesting that a new tribe be recognized for Tridynamia.

Van Ooststroom (1963) examined the type collection of T. eberhardtii, but was unable to decide whether or not to reduce it to synonymy with Porana. He commented that 
T. eberhardtii was very close to $P$. spectabilis Kurz, “... and may even be conspecific with it". In this revision $T$. eberhardtii is reduced to synonymy with $T$. megalantha.

\section{KEY TO THE SPECIES}

1a. Corolla blue or violet (rarely white); outer 2 sepals greatly elongate in fruit . . 2

b. Corolla white; outer 3 sepals greatly elongate in fruit $\ldots \ldots \ldots \ldots \ldots . \ldots 3$

2a. Corolla up to $1.1 \mathrm{~cm}$ across; all stamens included . . . . . . 17. T. bialata

b. Corolla (1-)1.6-3 cm across; some or all stamens exserted . . . 19. T. sinensis

3a. Corolla narrowly funnelform, tube widening gradually from base upward; fruiting sepals narrowly obovate to spathulate . . . . . . . 20. T. spectabilis

b. Corolla campanulate to broadly funnelform, tube flaring abruptly above a narrow base; fruiting sepals oblong . . . . . $\ldots \ldots \ldots \ldots \ldots \ldots$ 18. T. megalantha

\section{Tridynamia bialata (Kerr) Staples - Fig. 13e, f; Map 14}

Tridynamia bialata (Kerr) Staples (2004) 149. - Porana bialata Kerr (1941) 19. - Type: Put 3166 (lectotype (chosen here) BM; iso A, ABD, BK, E, K, L), Thailand.

Liana 2-20 m long; vegetative parts ferruginous; stem slender, basally woody; upper stems terete to angular, 2-3 mm diam., \pm puberulent, glabrate, pith solid. Indumentum yellowish to rusty; hairs 2-armed, arms mostly erect or ascending. Leaf petiole 1.4-4.5 cm long; blade broadly ovate to cordate, $5.5-10.2$ by $4.5-7.8 \mathrm{~cm}$, base cordate, apex acute to acuminate, rarely obtuse, apiculate, adaxially darker, pilose or subglabrous, abaxially paler, velutinous. Inflorescence a raceme or panicle, 10-25 cm long; lower bracts foliaceous; petiole $4-10 \mathrm{~mm}$; blade ovate to ovate-lanceolate, $2-2.5$ by $0.9-1.5$ $\mathrm{cm}$, puberulent; upper bracts sessile, lanceolate to subulate, 1-3 $\mathrm{mm}$ long; pedicels filiform, 4-8 $\mathrm{mm}$ long, thickening but not lengthening in fruit; bracteoles linearfiliform, 3-4 mm long, persistent, to 5-7 mm in fruit. Flowers odourless; buds narrowly fusiform, 7-9 mm long, apically acute or obtuse, puberulent. Sepals unequal, outer 2 narrowly elliptic-oblong, 3-4 mm long, basally tightly enveloping ovary, flaring and flat above, puberulent; inner 3 sepals shorter, ovate to lanceolate, $\leq 1 \mathrm{~mm}$ long, glabrous or apically tufted with hairs. Corolla $8-15$ by $7-11 \mathrm{~mm}$, pale bluish, centre yellowish, limb (sub)entire, outside puberulent on midpetaline bands, inside glabrous. Stamens unequal, included; filaments $2-5 \mathrm{~mm}$ long, sparsely pilose basally; anthers $<1 \mathrm{~mm}$ long; pollen 3-colpate, oblate spheroidal, c. 10 by $15-20 \mu \mathrm{m}$, surface psilate or minutely granulate. Pistil twice as long as calyx; ovary ovoid-globose, $<1 \mathrm{~mm}$ tall, attenuate into style, glabrous or apically hairy; ovules (1 or) 2; style filiform, 5-7 $\mathrm{mm}$, glabrous; stigma globose, $<1 \mathrm{~mm}$, entire to slightly emarginate. Fruiting calyx: outer 2 sepals linear-oblong, $3.5-5.4$ by $0.7-1.1 \mathrm{~cm}$, bases tightly surrounding utricle, constricted medially, flaring above, stiffly chartaceous, tan to brownish, subglabrous; inner 3 sepals unequal, ovate to lanceolate, 5-7 by 3-4 $\mathrm{mm}$, membranous, outside puberulent apically, otherwise glabrous. Utricle ovoid-conical, 6-10 by $3-4 \mathrm{~mm}$, apiculate by indurate style base, thinly chartaceous, tan to reddish brown, glabrous. Seed ellipsoid-oblong, 4-5 by $2-3 \mathrm{~mm}$, reddish brown to black, smooth, glabrous; hilum basal, circular, $<1 \mathrm{~mm}$ diameter.

Distribution - Thailand, Vietnam; probably also Laos and Cambodia. 


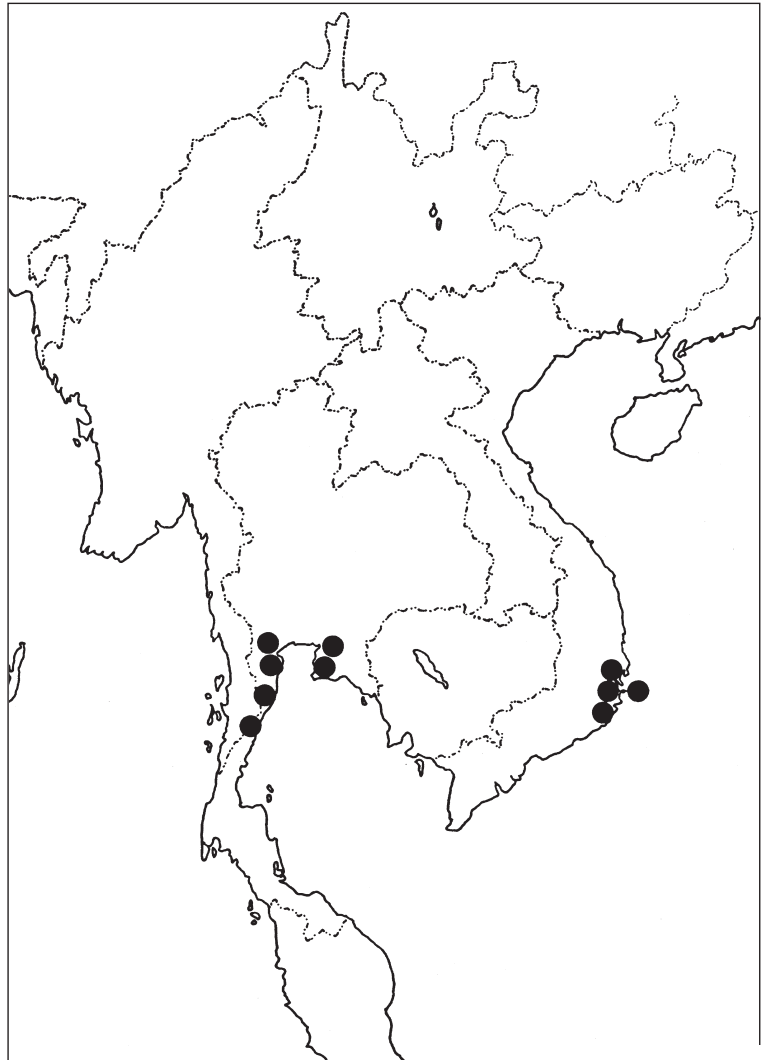

Map 14. Distribution of Tridynamia bialata (Kerr) Staples in south-eastern Asia.

Habitat - Forests, disturbed forests, scrub thickets, prairies, and near villages, on clay soils and among rocks and crags. At 20-300 m elevation.

Phenology - Flowering: April (1), August (2), September (1), October (1). Fruiting: January (4), February (2), September (1), November (1).

Vernacular names - Tap tao (Thailand, Prachuap Khiri Khan); bónga yang Hröi (Vietnam, Jörai dialect).

Notes - Tridynamia bialata is recognizable by the flowers c. $1 \mathrm{~cm}$ diam.; the pale bluish white corolla with yellow at the tube base; the unequal stamens included within the corolla throat; the biovulate ovary; the two outer sepals greatly enlarged in fruit, with the base tightly clasping the utricle, the middle portion inrolled/constricted, and the apical region flaring and flattened. The habit of this species is more delicate in comparison to its closest relative, $T$. sinensis.

Tridynamia bialata is the only species of the genus to have a biovulate ovary; all other taxa have 4-ovulate ovaries. The mosaic distribution of ovule number in the taxa formerly assigned to Porana s.l. demonstrates once again that this character is taxonomically uninformative for the Convolvulaceae at levels above the rank of species, a fact that was pointed out by Hallier (1893) and Van Ooststroom (1943). 


\section{Tridynamia megalantha (Merr.) Staples - Fig. 4a, 13a-d; Map 15}

Tridynamia megalantha (Merr.) Staples (1993) 201. - Porana megalantha Merr. (1935) 53. - Porana spectabilis Kurz var. megalantha (Merr.) F.C. How ex H.S. Kiu (1974) 475, f. 867. - Type: S.K. Lau 373 (holo NY; iso A, B, BM, E, G, K, MICH, MO, P, PE, UC, US, W), China.

Porana sutepensis Kerr (1941) 20. - Type: A.F.G. Kerr 2605 (lecto (chosen here) BM; iso A, K, L), Thailand, syn. nov.

Tridynamia eberhardtii Gagnep. (1950) 26. - Type: Eberhardt 3132 (holo P; iso P), Vietnam. Porana spectabilis auct. non Kurz (1873): Gagnep. \& Courchet (1915b: 293, f. 32), Kiu (1974), Fang \& Huang (1979a, b), Fang (1986).

Liana to $10 \mathrm{~m}$ long; lower stem 1-2.3(-4) cm diam., tan to brownish, bark corky, coarsely wrinkled; branches terete, 5-8 mm diam., wrinkled, dark brown, (sub) glabrous; stem tips terete, $2-3 \mathrm{~mm}$ diameter. Indumentum whitish to yellowish, tomentose to villose; hairs 2-armed, arms equal or not, erect or appressed. Leaf petiole $1.2-4(-7) \mathrm{cm}$, coarsely wrinkled; blade ovate, elliptic or suborbicular, 7.8 $-15(-19.7)$ by $5-9.3(-12.5)$ $\mathrm{cm}$, base cordate, rarely rounded or truncate, apex acute, acuminate or apiculate, texture stiffly chartaceous to subcoriaceous, adaxially darker, subglabrous to tomentose, abaxially tomentose-villous (rarely subglabrous). Inflorescence a simple or compound raceme, 19-48 cm long; lower bracts foliaceous, petiolate; petiole 4-17 mm long; blade ovate, $3.2-6.3$ by $1.5-4.2 \mathrm{~cm}$, base rounded or cordate, apex acute or apiculate;

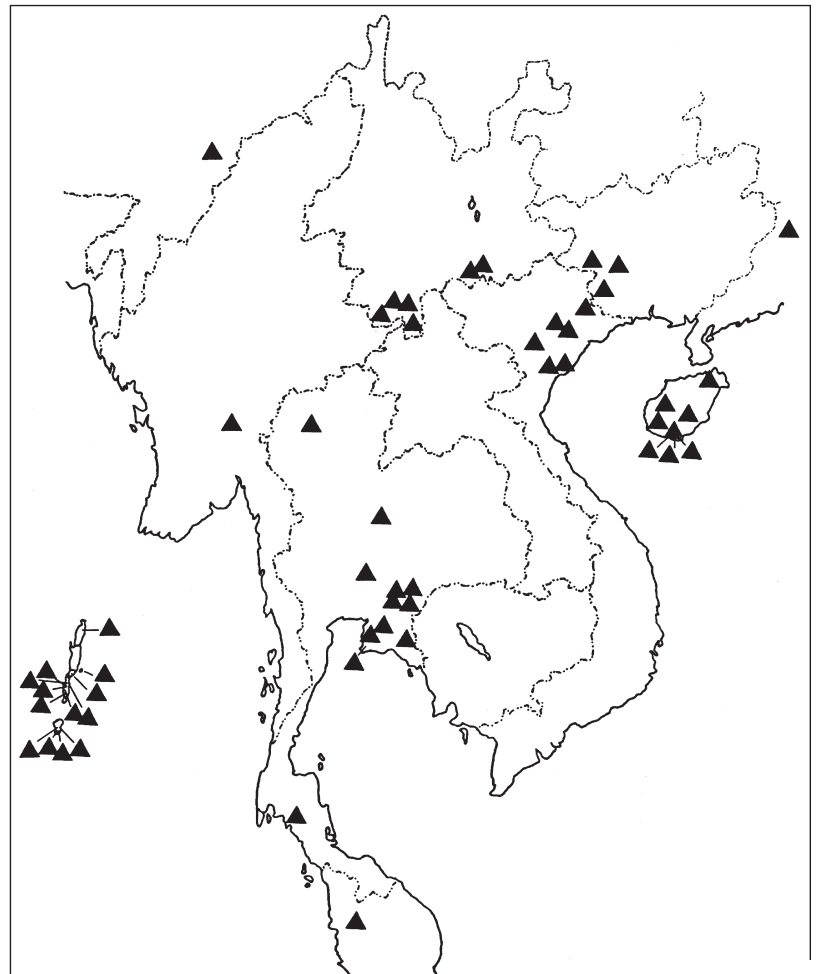

Map 15. Distribution of Tridynamia megalantha (Merr.) Staples in south-eastern Asia, China and the Andaman Islands. 
bracts diminishing upward, becoming sessile, uppermost scale-like, 1-3 mm long; pedicels flattish, 7-10 $\mathrm{mm}$ long, to $15 \mathrm{~mm}$ in fruit; bracteoles acute-ovate, unequal, 1-2 mm long, in fruit 5-6 by $2 \mathrm{~mm}$. Flowers showy, erect, odourless; buds ellipsoid, apex acute to obtuse, tomentulose. Sepals unequal, outer 3 narrowly oblong to linear, flat or revolute, $7-8$ by 1-2 $\mathrm{mm}$, base slightly broader, margins entire, apex rounded, outside glabrous basally, otherwise tomentose, midvein prominent abaxially; inner 2 sepals attenuate-lanceolate, curved around ovary, c. 4 by $1 \mathrm{~mm}$, outside tomentose, inside glabrous. Corolla flaring from base, subentire to 5-lobed, 3-4.5(-5) by 2.7-4.6 $\mathrm{cm}$, white, membranous, plicae and tube base glabrous outside, otherwise golden-brown tomentulose, glabrous inside. Stamens unequal, 11-17 mm long, included; filaments with a collar around attachment point on corolla tube; anthers c. $2 \mathrm{~mm}$ long, whitish; pollen 3- (or 4-)colpate, oblate spheroidal, 18-21 by 23-30 $\mu \mathrm{m}$, surface psilate, with pilate-multangulate structures inside colpi. Pistil to $19 \mathrm{~mm}$ long; disc absent; ovary broadly ovoid, 1-2 mm diam., attenuate into style, brownish basally, yellowish above, glabrous (sometimes obscured by style hairs); ovules 4; style filiform, 17-18 mm, lower half densely pilose, glabrous above; stigma biglobose, c. $1 \mathrm{~mm}$ diam., greyish tan. Fruiting calyx unequal, basally clasping utricle, flaring above; outer 3 sepals oblong, $5.5-7.5$ by $1-1.8 \mathrm{~cm}$, base medially thickened, forming a triangular keel, margins entire, apex rounded or obtuse (rarely acute), stiffly chartaceous, stramineous to tan, both sides \pm tomentulose, abaxially coarsely reticulate; inner 2 attenuate-lanceolate, wrapped around utricle, $15-26$ by $4-6 \mathrm{~mm}$, thinly chartaceous, yellowish tan, outside tomentulose, inside glabrous. Utricle borne erect, slenderly obovoid to ellipsoid, 10 by 6 $\mathrm{mm}$, apiculate, chartaceous, yellowish pilose. Seed narrowly obovoid to ellipsoid, 8-10 by $5-6 \mathrm{~mm}$, dark brown, wrinkled, glabrous; hilum semicircular, c. $1 \mathrm{~mm}$ diameter.

Distribution - NE India (and the Andaman Islands), Myanmar, Laos, N and E Thailand, Vietnam, S China (including Hainan Island).

Habitat - Grassy savannahs, roadsides, scrub, clearings and the edges of forests and thickets, stream banks and open sunny slopes on hills and steep mountains. Recorded from diverse soil types, often limestone; from sea level to $900 \mathrm{~m}$ elevation.

Phenology - Flowering: January (2), February (2), March (5), April (2), May (5), June (8), July (14), August (7), September (5), October (6), November (11), December (8). Fruiting: January (5), February (2), March (4), April (1), May (2), June (3), July (3), August (3), September (2), October (2), November (1), December (1).

Vernacular names - Dà hua fei é téng (China), dà hua yì é téng, máo máo (China, Guangxi); ladaa dong (central Thai dialect, ex Smitinand (1980) as Porana spectabilis Kurz).

Taxonomy - Tridynamia megalantha has been considered conspecific with T. spectabilis (Kurz) Parmar or reduced to varietal rank under it. Roberty (1952), without comment, reduced Porana megalantha to synonymy under his Poranopsis spectabilis. How in Kiu (1974), followed by Fang \& Huang (1979b), treated $P$. megalantha as a variety of $P$. spectabilis, distinguishing the two on the basis of flower size. This is a case of mistaken identity: no authentic material of $T$. spectabilis has been seen from China and the plants described by Chinese authors are all referable to T. megalantha. Although the holotype collection of $P$. megalantha bears quite large flowers relative to the species as a whole, flower size among the Chinese plants intergrades completely, thus rendering the recognition of varieties in $T$. megalantha quite artificial. However, flower size is 
useful in separating genuine T. spectabilis from T. megalantha: the largest flowers of $T$. spectabilis just reach the size of the smallest flowers of $T$. megalantha. The separation between the size distributions is almost complete. Based on these characters I maintain the two taxa at specific rank.

Notes - Characters diagnostic for T. megalantha are a campanulate to broadly funnelform corolla (Fig. 4a) that flares from just above the base, the corolla 3-4.5(-5) by $2.7-4.6 \mathrm{~cm}$, by the unusual 'collar' formed around each filament where it departs from the corolla tube (vide Gagnepain \& Courchet, 1915b: 293, f. 32, as P. spectabilis), and by the oblong outer three fruiting sepals. Additional, more subjective, characters include the usually whitish indumentum, the simple or only once or twice branched racemose inflorescences, and the reticulate abaxial surface of the outer fruiting sepals.

Within the wide geographic range of $T$. megalantha there is a clinal variation in the colour of the indumentum. Plants growing in the northern part of the range, from northeastern India across China to Hainan Island have a creamy or whitish indumentum, whereas plants growing further south, in Thailand, Laos and Vietnam, have a distinctly yellowish colour to the indumentum, giving the plants a yellow or brownish cast. The darkest individuals of T. megalantha approach the golden-brown to ferruginous colour of $T$. spectabilis.

Fang et al. (1986) report that this species (as Porana spectabilis and P. spectabilis var. megalantha) has several uses in folk medicine in Guangxi province, China. The uses include treatment for metroptosis, sprain, and chest distress. The plant parts used and the method of preparation are not explained.

\section{Tridynamia sinensis (Hemsl.) Staples - Map 16}

Tridynamia sinensis (Hemsl.) Staples (1993) 201. - Porana sinensis Hemsl. in Forbes \& Hemsley (1890) 167. - Type: C. Ford 290 (holo K; iso IBSC, P), China.

Porana esquirolii H. Lév. (1911) 444. - Type: J. Esquirol 976 (holo E, photo A; iso A, K), China. Vatica cordata Hu [Dipterocarpaceae] (1930) 225. - Type: R.C. Ching 7426 (holo PE; iso fragment A, IBSC, W), China.

Liana to $15 \mathrm{~m}$ long, climbing or prostrate; stem basally woody, terete to faintly striate, dark brown, glabrescent, sometimes fistulose when dry; young stems herbaceous, 4-5 mm diam., rusty or tawny pubescent. Indumentum rufous or tawny, velutinous to tomentose; hairs 2-armed, arms equal, appressed or erect. Leaf petiole (1-)2.7-6.2 $\mathrm{cm}$ long; blade ovate, elliptic-ovate to suborbicular, (4.4-) 8.5-13.2 by (1.9-)6.1-10 $\mathrm{cm}$, base shallowly cordate, emarginate, to rounded, margins entire or slightly revolute, apex acuminate to cuspidate, texture stiffly chartaceous to coriaceous, adaxially darker, subglabrous, abaxially paler, rufous to tawny velutinous or glabrous. Inflorescence a simple or compound raceme, $21-30 \mathrm{~cm}$ long; lower bracts foliaceous or absent, petiolate, petiole $6-15 \mathrm{~mm}$ long, blade ovate, $2.5-5.6$ by $1.4-4 \mathrm{~cm}$; upper bracts scale-like or absent; pedicels filiform, 10-16 mm; bracteoles unequal, largest ovate-lanceolate, $3-4$ by 1-2 $\mathrm{mm}$, attenuate-acuminate, folded medially, 2 smaller ovate to ovate-elliptic, 1-3 by 1-2 mm, obtuse, flat, persistent. Flowers erect; buds ellipsoidal, obtuse or acute, velutinous. Sepals unequal, outer 2 oblong, flat or slightly incurved, $4-5$ by $1-2 \mathrm{~mm}$, base subsagittate, margins entire, apex obtuse or rounded, outside glabrous basally, otherwise velutinous; inner 3 ovate to lanceolate, curved around ovary, $2-3(-4)$ by $1-2 \mathrm{~mm}$, base abruptly attenuate, third sepal asymmetrical 


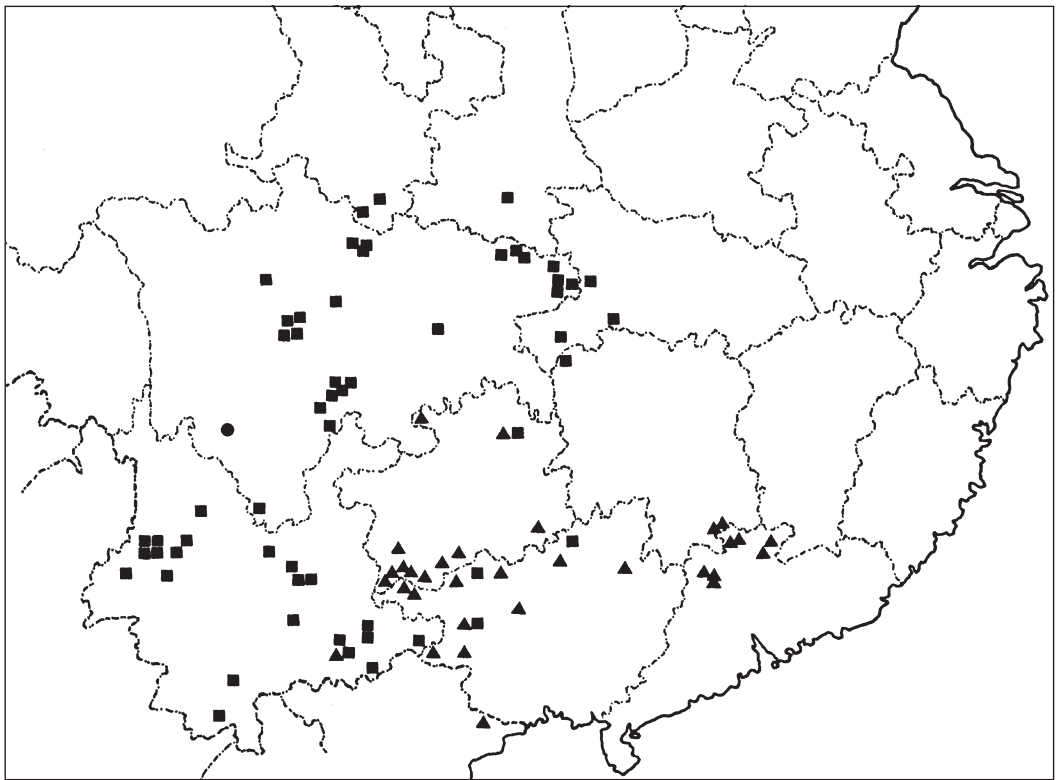

Map 16. Distribution of Tridynamia sinensis (Hemsl.) Staples var. sinensis $(\mathbf{\Delta})$ and T. sinensis (Hemsl.) Staples var. delavayi (Gagnep. \& Courchet) Staples ( $\square$ ) in China.

basally, margins entire, hyaline, apex attenuate to aristate, outside velutinous, inside glabrous or sparsely hairy; all sepals chartaceous; 3 longitudinal veins faintly visible. Corolla broadly funnelform, diaphanous, violet, blue-violet, pale blue, rose to white; tube (6-)8-10 mm long, glabrous inside and basally outside, velutinous above; limb flaring abruptly, reflexed, (1-)1.6-2.3(-3) cm diam., subentire or 5-parted, lobes broadly rounded, obtuse or apiculate, margins entire or sinuous, interplicae velutinous outside, corolla otherwise glabrous. Stamens \pm exserted from corolla, (7-)11-12 mm; filaments 5.5-10 mm; anthers 1.5-2 mm; pollen 3-colpate, oblate spheroidal, c. 15 by 18-20 $\mu \mathrm{m}$, surface psilate. Pistil 11-13 mm long, exserted; disc absent or 5-lobulate; ovary ovoid-conical, 1-2 mm long, black, glabrous below, velutinous distally with simple, appressed hairs; ovules ( 3 or) 4; style filiform, jointed above base, (5-)9-11 $\mathrm{mm}$, appressed pubescent below, glabrous distally; stigma globose, entire or \pm emarginate, $<1 \mathrm{~mm}$ diam., coarsely wrinkled, brownish. Fruiting calyx tightly clasping utricle; outer 2 sepals oblong to spatulate, $6.5-7.8$ by $0.9-1.4(-1.8) \mathrm{cm}$, base cuneate, medially thickened, keeled, margins entire, apex rounded-obtuse; third sepal variably enlarged, straight or falcate, $1-6.4$ by $(0.4-) 0.6-0.9 \mathrm{~cm}$; 2 inner sepals oblong-obovate, $8-11(-13)$ by $3.5-5(-7) \mathrm{mm}$, margins curved around utricle, sometimes ciliate, apex aristate; all sepals chartaceous, tan to pale brown, shiny or opaque, sparsely velutinous; veins darker, tertiary venation reticulate, prominulous abaxially. Utricle ellipsoid-ovoid or narrowly obovoid, $10-11$ by $6-8 \mathrm{~mm}$, apiculate, style remnant $3-5 \mathrm{~mm}$ tall, stiffly chartaceous, coarsely wrinkled, glabrous, dark brown below, rufous, sparsely pilose above middle. Seed ovoid to obovoid, $9-10$ by $6-8 \mathrm{~mm}$, dark brown to black, smooth or faintly striate, glabrous; hilum basal, circular, $\leq 1 \mathrm{~mm}$ diameter. 
Distribution - China, N Vietnam.

Notes - The diagnostic characters of $T$. sinensis are: the broadly funnelform corolla, to $2.5 \mathrm{~cm}$ diam. with reflexed limb; the (usually) long exserted pistil and stamens; the fruiting calyx with the outer two sepals greatly enlarged (Fig. 13g); the outer two fruiting sepals with a triangular median keel at the base, flat and slightly venose otherwise.

The degree of enlargement for the middle (third) fruiting sepal is variable in this species. In most fruiting collections the third sepal enlarges as much as the inner two sepals, e.g. much less dramatically than the outer two. In some cases, however, the third sepal enlarges to one quarter (C. Wang 40898, S. K. Lau 28682) or one half (A. Henry $10715 B$, MO specimen) the size of the outer two, and in at least one collection (R.C. Ching 7426), the middle sepal is fully as large as the outer two sepals. This condition appears in individual fruits rather than in every fruit on a given collection, and it appears in plants assigned to both varieties.

There is a clinal increase in flower size from west to east across this species' range. The smallest flowers, collected in western China (S.Y. Hu 1130), have a corolla tube only $6 \mathrm{~mm}$ long and a limb just $12 \mathrm{~mm}$ diameter. The largest flowers were collected in south-eastern China (Handel-Mazzetti 10877). A corresponding variation in stamen length is noticeable, with eastern populations having all stamens equal and exserted from the corolla throat, whereas some western populations have the stamens unequal, with the shorter ones reaching the corolla throat, but not exserted from it. Two partially allopatric varieties of $T$. sinensis are distinguishable.

\section{KEY TO THE VARIETIES}

1a. Plants rusty velutinous; leaf blade broadly ovate to suborbicular, base cordate. .

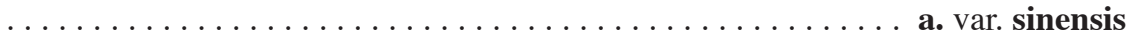

b. Plants subglabrous; leaf blades (narrowly) ovate, base truncate, rounded or emarginate $\ldots \ldots \ldots \ldots \ldots \ldots \ldots \ldots \ldots \ldots \ldots \ldots \ldots \ldots \ldots \ldots \ldots \ldots \ldots$ var. delavayi

a. var. sinensis - Fig. $13 \mathrm{~g}$, h; Map 16

For synonymy see under the species.

Pubescent liana to $15 \mathrm{~m}$ long. Leaf blade broadly ovate, elliptic ovate to suborbicular, $8.5-13.2$ by $6.1-10 \mathrm{~cm}$, base cordate or emarginate, apex \pm acuminate or cuspidate, adaxially subglabrous, abaxially rufous (to tawny) velutinous or tomentose. Corolla blue-violet, pale blue to white, tube 8-10 mm long, limb 19-23(-30) mm diam.; stamens equal, exserted, 11-12 mm; disc absent.

Distribution - China (Guangxi, Guizhou, Guangdong, S Hunan) and NE Vietnam. Its range overlaps that of var. delavayi along a broad zone through Guangxi and Guizhou provinces.

Habitat - Thickets, forests, stream banks, slopes and rock cliffs on soils recorded as rich and moist, or rocky and conglomerate in nature. It is not reported from limestone soils as frequently as is var. delavayi, and the specimen labels indicate that var. sinensis prefers more mesic habitats. At (100-)300-1300(-2500) m elevation.

Phenology - Flowering: April (1), May (8), June (4), July (4), August (3), September (3). Fruiting: May (3), June (3), July (3), August (1), September (5), December (1). 
Vernacular names - Da guo fei e teng (Chinese), mu lu hua (China, Guangxi).

Typification - The protologue for Vatica cordata, based on a single collection from Guangxi province, states that the fruit has "two linear, divergent wings." This agrees with the holotype and one isotype (IBSC), but the other isotype (W) has three \pm equally enlarged fruiting sepals. As noted above, there is variability in the degree to which the third sepal enlarges in fruit, and that is evident in the duplicates of Ching 7426.

Note - Tridynamia sinensis var. sinensis is recognized by its broadly ovate to suborbicular leaf blades with cordate base, and the rusty pubescence on the lower surface of the leaves, the bracts, and on the stem tips. Furthermore, the flowers are larger than in var. delavayi, the corolla tends to be lighter in colour, and the stamens are equal in length and clearly exserted from the corolla throat.

\section{b. var. delavayi (Gagnep. \& Courchet) Staples - Map 16}

Tridynamia sinensis (Hemsl.) Staples var. delavayi (Gagnep. \& Courchet) Staples (1993) 201. Porana delavayi Gagnep. \& Courchet (1915a) 153. - Porana sinensis Hemsl. var. delavayi (Gagnep. \& Courchet) Rehder (1934) 319. - Type: Delavay 3539 (lecto P; isolecto A), China. Porana confertifolia C.Y. Wu in Wu \& Li (1965) 104, t. 34, f. 2. - Type: F.T. Wang 22308 (holo KUN), China.

Liana 1.5-6.5 m long, glabrous or sparsely pubescent, indumentum tawny. Leaf blade narrowly ovate to elliptic ovate, $(4.4-) 8-14.2$ by $(1.9-) 4.1-9.2 \mathrm{~cm}^{1}$, base rounded (rarely truncate), emarginate, or shallowly cordate, apex attenuate-acuminate to apiculate, adaxially glabrous, abaxially glabrous or sparsely velutinous, especially along veins. Corolla violet, dark blue, purple with a white throat, or rarely rose-pink, tube 6-9(-10) mm long, limb subentire to 5-lobed, 10-20(-27) mm diam.; stamens 7-12 $\mathrm{mm}$ long, \pm exserted from throat; disc 5-lobulate or absent.

Distribution - China (C, W, and SW).

Habitat - Thickets, scrub and open situations along streams, roadsides, on cliffs and rock ledges and in lava beds; the soil is often recorded as rocky, frequently limestone, and dry. At 400-1800(-2200) m elevation.

Phenology - Flowering: April (1), May (13), June (10), July (17), August (8), October (1), December (1). Fruiting: June (1), July (1), August (5), September (1), October (5), November (3).

Vernacular name - Jìn wú máo fei é téng (Chinese).

Typification - Porana delavayi was effectively lectotypified by Huang in Fang \& Huang (1979a: 626). In her words [my translation], "The selected type specimen gathered from [Yunnan] Heqing (Jiangyun).” This statement can refer only to Delavay 3539, which was made in Jiangyun [romanized as Kiang-yu on the original label], now Heqing Xian.

Note - Tridynamia sinensis var. delavayi is separable from var. sinensis by its narrower leaves with the base not distinctly cordate (ranging from rounded or rarely truncate to emarginate, occasionally shallowly cordate) which are glabrous or, at most, sparsely velutinous on the lower side, and the generally smaller flowers. Its range overlaps that of variety sinensis along a wide band in Guizhou and Guangxi provinces.

1) It is likely that the leaf size of var. delavayi is here under-reported, since herbarium specimens rarely have full-sized cauline leaves present. 


\section{Tridynamia spectabilis (Kurz) Parmar - Fig. 13i-k; Map 17}

Tridynamia spectabilis (Kurz) Parmar (1994) 251. - Porana spectabilis Kurz (1873) 136. - Poranopsis spectabilis (Kurz) Roberty (1952) 26. - Type: S. Kurz 1083 (lectotype (chosen here) CAL sheet 314372; isolectotypes CAL sheet 314371, K), Myanmar.

Porana speciosa Benth. in Bentham \& Hooker f. (1876) 876, sphalm., 'spectabilis' ex B.D. Jacks. (1894) 606, based on the same type as Kurz's epithet.

Liana 6(-10) $\mathrm{m}$ long, vegetative parts tawny. Lower stem woody; branches terete, 5-6 $\mathrm{mm}$ diam., striate, brownish, sparsely tomentulose to glabrous; stem tips terete, $2-3 \mathrm{~mm}$ diam., herbaceous, tomentose. Indumentum yellowish ochraceous, tomentose; hairs 2-armed, arms erect or appressed. Leaf petiole $1.6-7 \mathrm{~cm}$ long, coarsely wrinkled; blade narrowly to broadly ovate or suborbicular, $7.1-19.5$ by $4-18 \mathrm{~cm}$, base emarginate to cordate, apex acute or obtuse, apiculate or mucronulate, stiffly chartaceous or subcoriaceous, adaxially olivaceous and subglabrous, abaxially yellowish olive, tomentulose. Inflorescence a panicle of racemes, $12.5-59 \mathrm{~cm}$ long, nodes with raised scars after flowers fall off; lower bracts foliaceous, petiolate, petiole $0.9-2.4 \mathrm{~cm}$ long, blade ovate, $5.2-7.2$ by $2.7-4.8 \mathrm{~cm}$, base rounded or cordate, apex acute, rounded, or emarginate; bracts diminishing in size apically, becoming sessile, uppermost subulate

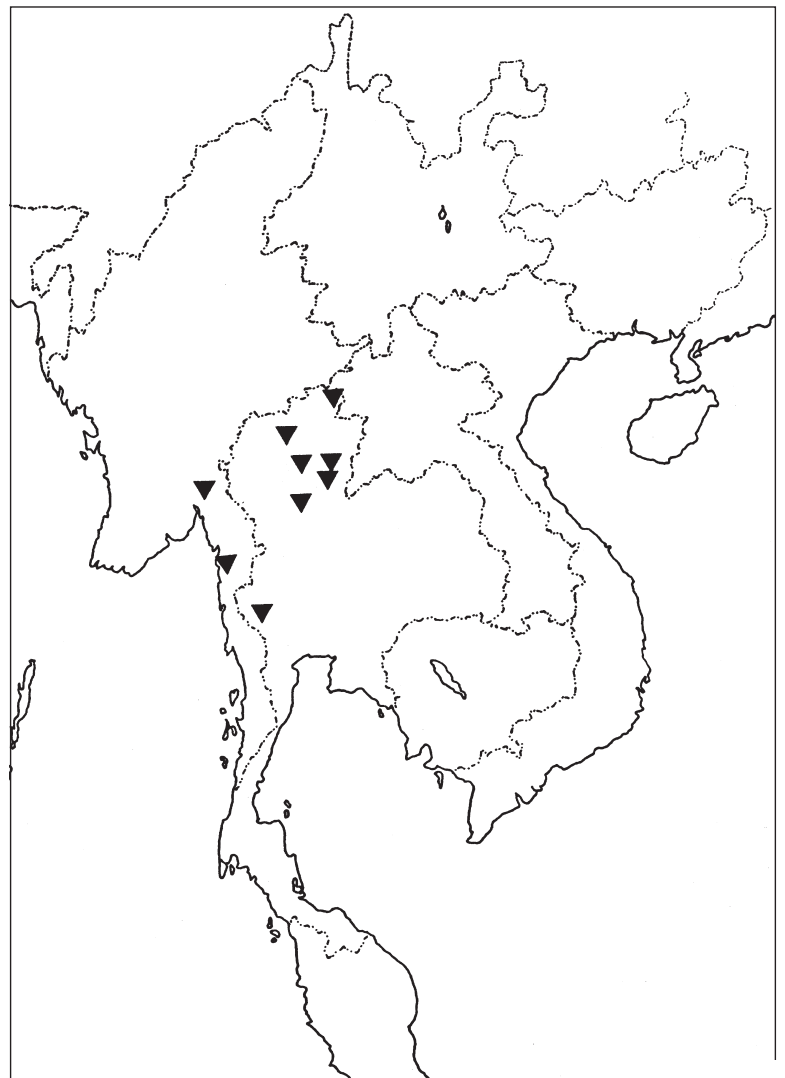

Map 17. Distribution of Tridynamia spectabilis (Kurz) Parmar in south-eastern Asia. 
to ovate, 4-7 mm long; pedicels flattened-filiform, $8-10 \mathrm{~mm}$; bracteoles ovate to ovate-lanceolate, unequal, 1-1.5 mm long, increasing to 3-4 $\mathrm{mm}$ in fruit. Flowers showy, sweetly fragrant; buds slenderly ellipsoid, 1.6-2.2 cm long, apex acute to obtuse, tomentose. Sepals unequal, outer 3 ovate-oblong, flat or incurved, 3-4 by $1 \mathrm{~mm}$, base broader, margins entire, apex rounded, texture herbaceous, with 1 (or 3) longitudinal ridges, glabrous basally outside, otherwise golden-brown tomentose; inner 2 ovate-lanceolate, clasping corolla tube base, $2-3$ by $1 \mathrm{~mm}$, lower margins hyaline, apex attenuate, tomentose outside except on hyaline margins, glabrous inside. Corolla narrowly funnelform, $1.9-2.7(-3.3)$ by $1.7-2.3(-2.7) \mathrm{cm}$, white, membranous, glabrous inside; tube gradually flaring, base glabrous, otherwise yellowish tomentose; limb 5-lobed, lobes obtuse to rounded, tomentose outside. Stamens unequal, included; filaments 6-10 mm; anthers c. $2 \mathrm{~mm}$ long; pollen 3-colpate, oblate spheroidal, 18-20 by $22-24 \mu \mathrm{m}$, surface psilate. Pistil included in corolla throat, $12-13 \mathrm{~mm}$ long; disc absent; ovary ovoid, attenuate into style, c. 1 by $1 \mathrm{~mm}$, dark brown below, yellowish distally, glabrous; ovules 4; style 10-12 mm, appressed pilose on lower half, glabrous above; stigma biglobose, taller than broad, c. $1 \mathrm{~mm}$ diam., greyish tan. Fruiting calyx (immature) clasping utricle basally, flaring above; outer 3 sepals greatly enlarged, narrowly obovate-spathulate, flat, $4.9-5.5$ by $1.1-1.5 \mathrm{~cm}$, base medially thickened, keeled, margins entire, apex rounded to obtuse, stiffly chartaceous, greenish to tan, outside slightly reticulate, sparsely tomentulose to subglabrous; inner 2 linear-lanceolate, incurved around the utricle, $15-16$ by $3-4 \mathrm{~mm}$, apex long attenuate, thinly chartaceous, pale tan, glabrous inside, sparsely tomentulose outside. Utricle (immature) obovoid, c. 6 by $5 \mathrm{~mm}$, apically rounded, densely yellowish tomentose. Seed (immature) obovoid, c. 5 by $3 \mathrm{~mm}$, dark brown to blackish, glabrous.

Distribution - SE Myanmar (Karen and Mon States), W Thailand.

Habitat - Evergreen forests, mixed deciduous/evergreen forests, hardwood forests, and moist upper deciduous forests, along streams and on the edges of clearings. The soil type, when recorded, is exclusively limestone. At 100-550 m elevation.

Phenology - Flowering: January (5), February (9), March (1), July (1). Fruiting: July (1), December (1).

Vernacular names - Ladaa dong (Central Thai dialect, ex Smitinand, 1980).

Notes - Tridynamia spectabilis is recognizable by the narrowly funnelform corolla (Fig. 4b), 1.9-2.7(-3.3) by $1.7-2.3(-2.7) \mathrm{cm}$, the tube widening gradually from the base upwards, the limb flaring out from it more or less abruptly; the staminal filaments flattened and fused to the corolla tube below, lacking a 'collar' at the point where the free portion of the filament departs from the corolla tube; the narrowly obovate to spathulate outer three fruiting sepals. Furthermore, plants of T. spectabilis have a golden-brown or yellowish indumentum, the inflorescence is a panicle composed of racemes, and the three outer fruiting sepals are smooth or only slightly reticulate on the abaxial surface.

Tridynamia spectabilis shares the common features of a white corolla and three outer sepals greatly enlarged in fruit with $T$. megalantha. For a discussion of the confusion between the two see under T. megalantha. As defined here, T. spectabilis has a restricted distribution in Myanmar and western Thailand. 


\section{EXCLUDED SPECIES}

The following list accounts for several names published in the genus Porana that are extralimital to the present treatment. Types and pertinent literature are cited for all taxa.

Porana acuminata P. Beauv. (1806) 66, t. 39. - Type: Palisot de Beauvois s.n. (holo G; iso P), Nigeria = Neuropeltis acuminata (P. Beauv.) Benth. (1849) 469.

Porana densiflora Hallier f. (1894) 93. - Type: Fischer 284 (holo B, destroyed, fragment GOET), East Africa, sine loco = Metaporana densiflora (Hallier f.) N.E. Br. (1914) 169; Staples (1990) 253-254.

Porana obtusa Balf.f. (1883) 83. - Type: Balfour, Cockburn \& Scott 355 (holo K; iso BM, E, fragment GOET, LE), Socotra = Metaporana obtusa (Balf.f.) Staples (1990) 253.

Porana parvifolia K. Afzel. (1929) 182. - Type: K. Afzelius s.n. (holo S; iso S, photo K), Madagascar = Metaporana parvifolia (K. Afzel.) Verdc. (1969) 291.

Porana subrotundifolia De Wild. (1902) 111. - Type: Verdick 525 (lectotype (here designated) BR), Democratic Republic of Congo $=$ Paralepistemon shirensis (Oliv.) Lejoly \& Lisowski (1986) 197.

Porana velutina (M. Martens \& Galeotti) Hallier f. (1893) 538, Dufourea? velutina M. Martens \& Galeotti (1845) 259. - Type: (lectotype (chosen here): 2nd sheet BR; isolectotypes: 1st sheet BR, G, P, W), Mexico = Porana nutans (Sessé \& Moç. ex Choisy) O’Donell (1960) 62.

\section{ACKNOWLEDGEMENTS}

This paper is derived from a doctoral dissertation submitted to the Department of Organismic and Evolutionary Biology, Harvard University. Funding was provided by the Atkins Fund, Anderson Fund, and Fernald Fund, all of Harvard University, and by the National Science Foundation, under awards BSR 85-00832 and 0212762.

The Harvard University Herbaria (A, GH, ECON) and the Harvard Botany Libraries provided the institutional base for the research while the Bernice P. Bishop Museum (BISH) enabled later revision and publication. The directors and curators of the herbaria AAU, ABD, B, BK, BKF, BLAT, BM, BR, BRI, BSA, C, CAL, CANB, CDBI, CMU, DD, E, F, FI, G, GOET, GXMI, H, HBG, HITBC, IBK, IBSC, K, KATH, KKU, KLU, KUH, KUN, KYO, L, LE, LIV, LWG, M, MEL, MICH, MO, N, NA, NAS, NY, P, PE, PERTH, PNH, PSU, QBG, RAF, S, SAN, SING, SYS, SZ, TAI, U, UC, UKMB, US, UWA, W, WH, WU, and YUKU loaned specimens or permitted visits to study material. Herbarium specimens of Porana and its allies are nowhere abundant and I am grateful to have been permitted to retain loans so that comparative study was possible.

Numerous individuals provided assistance essential to these studies. In particular I wish to thank E.A. Shaw for correcting my Latin diagnoses, I. Al-Shehbaz for illustrating the new species and A. Stone for preparing the plates for each genus and the cleared sepals; my graduate advisory committee (R.A. Howard, chair, D.E. Boufford, M.D. Bowers, P.F. Stevens) for their guidance and support; S.-Y. Hu for tutoring me in the Chinese language; K. Anderson, C. Imada, and P. O'Connor for help with electronic document translation, data entry, and editorial improvements; and an anonymous reviewer for suggesting further improvements. 


\section{REFERENCES}

Afzelius, K. 1929. Sur deux Convolvulacées nouvelles de Madagascar. Svensk Botanisk Tidskrift 23, 2: 179-183.

Austin, D.F. 1971. An addition and nomenclatural change in the tribe Poraneae (Convolvulaceae). Ann. Missouri Bot. Gard. 58: 243-244.

Baillon, H. 1891. Histoire des Plantes. vol. 10. Paris.

Balfour, B. 1883. Diagnoses plantarum novarum phanerogamarum Socotrensium, pars III. Proc. Roy. Soc. Edinburgh 12: 76-98.

Beauv., P. - see Palisot de Beauvois

Bentham, G. 1849. Convolvulaceae: 464-471. In: J.D. Hooker \& G. Bentham, Flora nigritiana: 203-587, t. 50. In: W.J. Hooker (ed.), Niger Flora. Baillière, London.

Bentham, G. \& J.D. Hooker. 1876. Genera plantarum. Vol. 2. Reeve \& Co., London.

Blume, C. 1825-1826. Bijdragen tot de flora van Nederlandsch Indië. Lands Drukkerij, Batavia.

Brown, N.E. 1914. Diagnoses Africanae LIX. Bull. Misc. Inform. Kew 1914: 167-171.

Brown, R. 1810. Prodromus florae Novae Hollandiae. Taylor \& Co., London.

Burman, N.L. 1768. Flora Indica. Haek, Amsterdam.

Choisy, J.D. 1834. Convolvulaceae Orientales. [A separately paged reprint from Mém. Soc. Phys. Genève 6: 385-502, 6 tabs.]

Choisy, J.D. 1837. De Convolvulaceis dissertatio secunda. [A separately paged reprint from Mém. Soc. Phys. Genève 8: 43-86.]

Choisy, J.D. 1845. Convolvulaceae. In: A. de Candolle, Prodromus systematis naturalis regni vegetabilis 9: 323-465, 565. Fortin, Masson \& Cie., Paris.

Clarke, C.B. 1883. Convolvulaceae. In: J.D. Hooker, The Flora of British India, vol. 4: 179-228, 734. Reeve \& Co., London.

Dalzell, N.A. \& A. Gibson. 1861. The Bombay flora. Education Society's Press, Bombay.

De Wildeman, E.A.J. 1902-1903. Études sur la flore du Katanga. Ann. Mus. Congo, Sér. IV, Bot. 1: 111 . t. 5 , f. $8-18$.

Deroin, T. 2001. Convolvulaceae. Famille 171. Flore de Madagascar et des Comores. Muséum National d'Histoire Naturelle, Paris.

Deroin, T. 2004. Anatomie florale comparée de Cardiochlamys et Cordisepalum. Illustration de l'hétérobathmie des Convolvulaceae-Cardichlamyeae. Adansonia, ser. 3, 26, 2: 199-211.

Don, D. 1825. Prodromus florae Nepalensis. Gale \& Co., London.

Endlicher, S. 1839 [1836-1840]. Genera plantarum. Beck Univ. Publ., Vienna.

Engler, A. 1886. Die auf der Expedition S.M.S. "Gazelle" von Dr. Naumann im malayischen Gebiet gesammelten Siphonogamen (Phanerogamen). Bot. Jahrb. Syst. 7: 444-480.

Erdtman, G. 1952. Pollen morphology and plant taxonomy, an introduction to palynology. Almqvist \& Wiksell, Stockholm.

Fang, D. et al. 1986. Guangxi yaoyong zhi wu minglu [List of Medicinal Plants in Guangxi]. Nanning. [In Chinese.]

Fang, R.C. \& S.H. Huang. [March] 1979a. Convolvulaceae. In: C. Y. Wu (ed.), Flora yunnanica 2: 611-686.

Fang, R.C. \& S.H. Huang. [May] 1979b. Convolvulaceae. In: C.Y. Wu (ed.), Flora Reipublicae Popularis Sinicae 64: vii + 184 pp., tabs. Beijing.

Forbes, F.B. \& W.B. Hemsley. 1890 [1889-1902]. Index florae sinensis 2: 1-592. Longmans, Green, \& Co., London. [Simultaneously published in J. Linn. Soc. Bot. 26: 1-592.]

Forman, L.L. 1997. Notes concerning the typification of names of William Roxburgh's species of phanerogams. Kew Bull. 52: 513-534.

Gagnepain, F. 1950. Genres nouveaux, especes nouvelles d'Indochine, part 2. Notul. Syst. (Paris) 14: $22-37$.

Gagnepain, F. \& L.D. J. Courchet. 1915a. Convolvulacées Asiatiques nouvelles. Notul. Syst. (Paris) 3: $134-155$.

Gagnepain, F. \& L.D.J. Courchet. 1915b. Convolvulacées. In: H. Lecomte (ed.), Flore Générale de l'Indochine. Vol. IV. Masson \& Cie., Paris. 
Gaudichaud, C. 1829 ('1826'). Botany. In: L. Freycinet, Voyage autour du monde. vol. 1. Paris, Pillet Ainé. [pp. 433-464 published 28 Sept. 1829.]

Govil, C.M. 1972. Morphological studies in the family Convolvulaceae. IV. Vascular anatomy of the flower. Proc. Indian Acad. Sci., B, 75, 6: 271-282.

Hallier, H. 1893. Versuch einer natürlichen Gliederung der Convolvulaceen auf morphologischer und anatomischer Grundlage. Bot. Jahrb. Syst. 16: 453-591.

Hallier, H. 1894 ('1893'). Convolvulaceae Africanae. Bot. Jahrb. Syst. 18: 81-160.

Handel-Mazzetti, H. 1920. Plantae novae Sinenses 6. Kaiserl. Akad. Wiss. Wien, Math.-Naturwiss. Kl. 57, 19: 241.

Handel-Mazzetti, H. 1921. Plantae novae Sinenses 14. Kaiserl. Akad. Wiss. Wien, Math.-Naturwiss. Kl. 58, 26/27: 227-233.

Handel-Mazzetti, H. 1923. Plantae novae Sinenses 19. Kaiserl. Akad. Wiss. Wien, Math.-Naturwiss. Kl. 60, 13: 98.

Handel-Mazzetti, H. 1936. Symbolae Sinicae 7, 2: 731-1450. Springer Verlag, Vienna.

Handel-Mazzetti, H. 1938. Kleine Beiträge zur Kenntnis der Flora von China. VII. Oesterr. Bot. Z. 87: $119-133$.

Hu, H.H. 1930. Notulae systematicae ad floram sinensem, II. J. Arnold Arbor. 11: 224-227.

Jackson, B.D. 1894. Index Kewensis Vol. 3. Clarendon Press, Oxford.

Jacquin, J.F. 1844. Eclogae plantarum rariorum Vol. 2. Strauss, Vindobonae.

Jussieu, A.L. 1789. Genera Plantarum. Herissant, Paris.

Kerr, A.F.G. 1941. Contributions to the Flora of Thailand. Additamentum LIV. Bull. Misc. Inform. Kew 1941: 8-21.

Kiu, H.S. 1974. Convolvulaceae. In: W.Y. Chun \& C.C. Chang (ed.), Fl. Hainanica. 3: 471-495, 586-587. Xinhua Publish., Beijing.

Kurz, S. 1873. Descriptions of three new species of Porana. J. Bot. 11: 136-138.

Lamarck, J.B. 1804. Encyclopédie Méthodique 5: 568-569, t. 186. Agasse, Paris.

Lawrence, G.H.M. 1951. Taxonomy of vascular plants. Macmillan Publ. Co., Inc. New York.

Ledebour - see Von Ledebour

Lejoly, J. \& S. Lisowski. 1986. Paralepistemon, nouveau genre de Convolvulaceae d'Afrique tropicale. Bull. Jard. Bot. Belg. 56: 195-197.

Léveillé, H. 1911. XCVI. Decades plantarum novarum. LIX-LXX. Repert. Spec. Nov. Regni Veg. 9: 441-463.

Léveillé, H. 1916 [1915-1917]. Catalogue des plantes du Yun-Nan. Privately published, Le Mans.

Linnaeus, C. 1771. Mantissa plantarum altera: 143-587. Laurentii Salvii, Stockholm.

Manitz, H. 1983. Die Cytologie der Convolvulaceae und Cuscutaceae I. Zusammenstellung der bekannten Chromosomenzahlen. Wiss. Z. Friedrich-Schiller-Univ. Jena, Math.-Naturwiss. Reihe 32: $915-944$.

Martens, M. \& H. Galeotti. 1845. Enumeratio synoptica plantarum phanerogamicarum in regionibus mexicanis ab Henrico Galeotti, collectarum. Bull. Acad. Roy. Sci. Bruxelles 12, 9: 257-273 [Convolvulaceae].

Melchior, H. 1964. Engler's Syllabus der Pflanzenfamilien, ed. 12. Borntraeger, Berlin.

Merrill, E.D. 1921. A review of the new species of plants proposed by N.L. Burman in his Flora Indica. Philipp. J. Sci. 19: 329-388.

Merrill, E.D. 1935. A sixth supplementary list of Hainan plants. Lingnan Sci. J. 14: 1-62.

Moore, P.D. \& J.A. Webb. 1978. An illustrated guide to pollen analysis. Halsted Press, John Wiley \& Sons, New York.

Mueller, F. [J.H.] von - see Von Mueller

Myint, T. \& D.B. Ward. 1968. A taxonomic revision of the genus Bonamia (Convolvulaceae). Phytologia 17: 121-239.

O'Donell, C.A. 1941. Revision de las especies americanas de "Merremia" (Convolvulaceae). Lilloa 6: 467-554.

O’Donell, C.A.1960. Notas sobrea Convolvuláceas Americanas. Lilloa 30: 39-69.

Oliver, D. 1883. Cardiochlamys madagascariensis Oliv. Hooker's Icon. Pl. 15: 2, t. 1403.

Palisot de Beauvois, A.M.F.J. 1804 [1806]. Flore d'Oware et de Bénin, en Afrique. vol. 1. Paris. 
Parmar, P.J. 1994. New combinations in the family Convolvulaceae. J. Econ. Taxon. Bot. 18, 2: 251-252.

Pax, F. 1922. Aufzählung der von Dr. Limpricht in Ostasien gesammelten Pflanzen. Repert. Spec. Nov. Regni Veg. Beih. 12, II Teil: 298-515.

Perry, L.M. 1980. Medicinal plants of east and southeast Asia. MIT Press, Cambridge, MA.

Peter, A. 1891. Convolvulaceae. In: A. Engler \& K. Prantl, Die natürlichen Pflanzenfamilien. IV.3.a: 1-40. Leipzig.

Radford, A.E., W.C. Dickison, J.R. Massey \& C.R. Bell. 1974. Vascular plant systematics. Harper \& Row, New York.

Rehder, A. 1934. Notes on the ligneous plants described by Léveillé from eastern Asia. J. Arnold Arbor. 15: 267-326.

Robertson, K.R. 1971. A revision of the genus Jacquemontia (Convolvulaceae) in North and Central America and the West Indies. PhD thesis, Washington Univ., St. Louis, MO. University Microfilms copy.

Roberty, G. 1952. Genera convolvulacearum. Candollea 14: 11-60.

Roberty, G. 1964. Les genres de Convolvulacées (esquisse). Boissiera 10: 129-156.

Roxburgh, W. 1814. Hortus bengalensis. The Mission Press, Serampore.

Roxburgh, W. 1819 ('1815'). Plants of the Coast of Coromandel. vol. 3. Bulmer \& Co., London.

Roxburgh, W. 1824. In: W. Carey (ed.). Flora Indica. vol. 2. The Mission Press, Serampore.

Savage, S. 1945. A catalogue of the Linnaean herbarium. Taylor \& Francis, Ltd., London.

Savage, S. 1963. Catalogue of the Smithian Herbarium (the Herbarium of Sir James Edward Smith, M.D., F.R.S., first President of the Linnean Society of London) in the possession of the Linnean Society of London. 4 vols.

Schimper, W.P. \& J.A. Schenk. 1890. Handbuch Palaeont. Palaeophyt. Druck \& Verlag R. Oldenbourg, München/Leipzig.

Schneider, C. 1916. Convolvulaceae. In: C.S. Sargent, Plantae wilsonianae 3. Harvard Univ. Press, Cambridge, MA.

Shenoy, K.N. \& J.A. Inamdar. 1985. Cotyledonary leaf architecture of some Convolvulaceae. Acta Bot. Indica 13: 10-17.

Smith, W. 1914. Diagnoses specierum novarum in herbario Horti Regii Botanicii Edinburgensis cognitarum. LI-CII. Notes Roy. Bot. Gard. Edinburgh 8: 173-212.

Smitinand, T. 1980. Thai plant names (botanical names - vernacular names). Funny Publishing Ltd., Bangkok.

Sprengel, K.P. 1825 [late 1824]. Systema Vegetabilium ed. 16, Vol. 1. Librariae Dieterichianae, Gottingae.

Staples, G. 1987a. A revision of Porana Burm.f. (Convolvulaceae) and an evaluation of the tribe Poraneae. PhD dissertation, Department of Organismic \& Evolutionary Biology, Harvard University, Cambridge, MA.

Staples, G. 1987b. The genus Porana (Convolvulaceae) in Australia. Nuytsia 6, 1: 51-59.

Staples, G. 1990. Preliminary taxonomic consideration of the Poraneae (Convolvulaceae). J. Arnold Arbor. 71: 251-258.

Staples, G. 1993. New combinations in the tribe Poraneae (Convolvulaceae) for the Flora of China. Novon 3: 198-201.

Staples, G.W. 2004. Two new combinations in Thai Convolvulaceae. Thai Forest Bull., Bot. 32: 149-150.

Staples, G.W. \& F. Jacquemoud. 2005. Typification and nomenclature of the Convolvulaceae in N.L. Burman's Flora Indica with an introduction to the Burman collection at Geneva. Candollea 60, 2: $445-467$.

Stefanovic, S., D.F. Austin \& R.G. Olmstead. 2003. Classification of Convolvulaceae: a phylogenetic approach. Syst. Bot. 28: 791-806.

Stefanovic, S., L. Krueger \& R.G. Olmstead. 2002. Monophyly of the Convolvulaceae and circumscription of their major lineages based on DNA sequences of multiple chloroplast loci. Amer. J. Bot. 89: 1510-1522.

Sweet, R. 1825. The British flower garden 2: t. 127. Simpkin \& Marshall, London. 
Sweet, R. 1827. Hortus Britannicus. Ridgway, London.

Talbot, W.A. 1894. Systematic list of the trees, shrubs and woody climbers of the Bombay Presidency. Government Central Press, Bombay.

Van Ooststroom, S.J. 1934. A monograph of the genus Evolvulus. Meded. Bot. Mus. Herb. Rijks Univ. Utrecht 14: 1-267.

Van Ooststroom, S.J. 1938. The Convolvulaceae of Malaysia, I. Blumea 3: 62-94.

Van Ooststroom, S.J. 1943. The Convolvulaceae of Malaysia IV. Blumea 5: 339-411.

Van Ooststroom, S.J. 1963. Reduction of Gagnepain's genera Cryptanthela, Dimerodiscus, and Tridynamia (Convolvulaceae). Blumea 12: 39-40.

Van Ooststroom, S.J. \& R.D. Hoogland. 1953. Convolvulaceae. Flora Malesiana, Ser. I, 4: 388-512.

Verdcourt, B. 1969. Corrections and additions to the 'Flora of Tropical East Africa - Convolvulaceae': III. Kew Bull., 23: 291.

Verdcourt, B. 1970. A suggested identity of Ipomoea cuspidata D.Don. Kew Bull. 24: 455.

Verdcourt, B. 1971. The genus Cardiochlamys Oliv. (Convolvulaceae). Kew Bull. 26: 137-140.

Von Ledebour, C.F. 1824. Indicis Seminum Horti Academici Dorpatensis, suppl. II: 1-7. Dorpati, Livonorum.

Von Mueller, F.J.H. 1860. Fragmenta phytographiae Australiae. Vol. 2. Governor of the Colony of Victoria, Melbourne.

Von Mueller, F.[J.H.] 1868 ('1867'). Fragmenta phytographiae Australiae. Vol. 6. Melbourne.

Wight, R. 1843. Illustrations of Indian Botany 2: t. 168bis, fig. legend 208.

Wight, R. 1850. Icones Plantarum Indiae Orientalis 4: 14, t. 1376.

Willis, J.C. 1973. In: H.K. Airy Shaw (ed.), A dictionary of the flowering plants and ferns. 8th ed. Cambridge Univ. Press, London.

Wu, C.Y. \& X.W. Li. 1965. Yunnan Ruodai ya Ruodai zhiwu quxi yanjiu baogao [Yunnan Trop. \& Subtrop. Florist. Res. Rep.] 1: 1-146, 38 plates. [In Chinese with Latin nomenclature.]

Zhongguo ke xue yuan, zhi wu yan jiu suo [Academia Sinica, Institute of Botany]. 1974. Iconographia cormophytorum sinicorum. Vol. 3. Xinhua Publ., Beijing.

Zollinger, H. 1846. Observationes phytographicae genera et species nova nonnulla. Natuur-Geneesk. Arch. Ned.-Indië 2: 563-587.

\section{IDENTIFICATION LIST}

The numbers after the collector numbers refer to the following taxa:
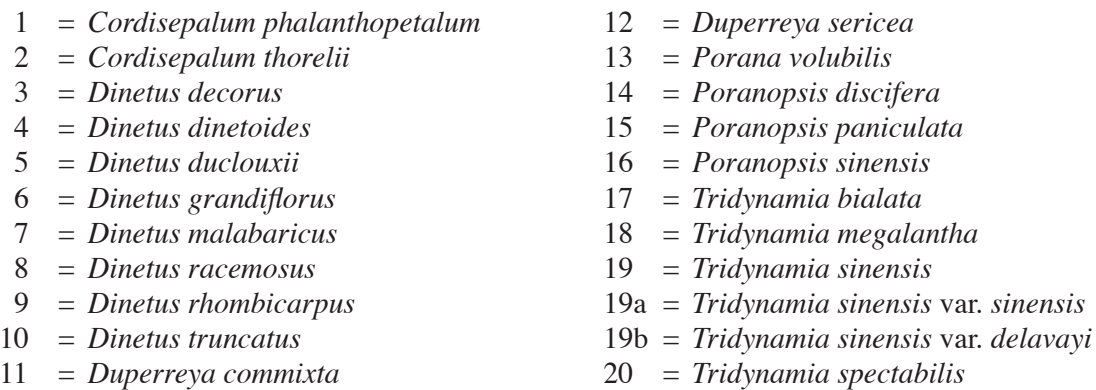

Abbott 2751: 15 - Acad. Sci. Exped. 216: 8; 24482: 8 - Acad. Sinica Exped. 268: 8 - Afriastini 1558: 13 - Aitken \& Hutchinson HA62: 11 - Akpabla 425: 3 - Althofer 147: 11 - Anchuan Team 1312: 8 - Anderson \& Smitinand 7219: 14 - Angus 3534: 15 - Anonymous 5230: 5; 8714: 5 - Aplin 2407: 11; 2547: 12 - Arañez 23: 13 - Arens 75: 8 - Ashby 2266: 12 - Austin \& Austin 6081: 15 - Averyanov et al. CBL 419: 8; VH 2118: 8 - Awasthi 1995: 8.

Backer 7765: 13; 7977: 13; 13386: 8; 36157: 13; 37335: 8 - Bal 444: 8 - Balakrishnan 731: 18 - Balansa 4434: 8 - Balsinhas: 1894: 15 - Ban 474: 8 - Banerji 1215: 8; 1381: 6 - Banerji et al. 2742: 6 - Bangham \& Bangham 657: 13 - Bartholomew et al. 984: 8; 1256: 8; 1888: 10?; 
1905: 10?; 2473: 10? - Basu 6842: 18 - Bauer 49: 13 - Beaglehole 11546: 11 - Beard 2082: 12; 2871: 11; 3636: 12 - Beddome 5623: 15; 5625: 13; 5626: 13 - Bena 313: 15 - Bhargava 3389: 18; 6530: 18; 6554: 18 - Bhattacharya 10238: 15; 17789: 15 - Bhattacharya \& Sajn 75/2810: 15 - Bhorai 858: 15 - Bi Zhu-yang 1380: 19a - Biegel 5810: 15 - Billore 112976: 7; 115604: 7 - Bishop \& Bishop WF25: 6 - Bista 3215: 6; 3645A: 6 - Biswas 205: 6; 1683: 15; 4048: 8; 5682: 8; 5888: 8 - Bjornland \& Schumacher 558: 10 - BKF herb. 15736: 8 - Bock \& Van Rosthorn 3135: 8 - Bodinier 1956: 8; 1956bis: 8 - Bole 156: 8 - Bon 2634: 18; 2690: 18 - Bonati 3452: 16 - Bor 2478: 8; 6188: 8; 6384: 4; 6690: 14 - Bot. Garden Organization staff (BGO) 68: 14; 2852: 10; 5279: 8; 9740: 8 - Bot. Survey of India-Western Circle 12584: 7 - Brandis 3062: 15 - Brandis herb. 556: 10 - Brinkman 801: 8 - Brumbach 7733: 15 - Bui Duc Binh 101: 8 - Bunchuai 1015: 14; 1413: 8; 1429: 8 - Buner-Johnston 17: 15 - Bünnemeijer 11730: 8 - Burbridge 6456: 12 - Burkill 28170: 15; 29479: 15; 35793: 15 - Bush 357: 15 - Byrnes 4028: 12.

Cai Xi-tao 58-8241: 19b; 58-8266: 4; 58-8342: 4; 58-8451: 5; 58-8518: 8; 58-9104: 5; 80070: 16 - Campbell 72: 12 - Cao Zi-yu 506: 19a - Carr 376: 12 - Cavalerie 441: 8; 2386: 19a - Cave 72: 8 - Chadwick 1490: 11; CR8 101: 11 - Chamla 89: 15 - Chandh 93: 15 - Chandra 12389: 15 - Chandra et al. 43500: 15; 43979: 15 - Chaney 163: 8 - C.C. Chang 10037: 8; 10658: 8; 13348: 10; 14055: 8 - H.T. Chang 5491: 8; 5532: 8; 5933: 8; 5972: 8; 7090: 8; 7095: 8 - T.S. Chang \& Y.T. Chang 1352: 19a; 2290: 19a; 2395: 19a; 2525: 19a; 3105: 19a; 3356: 19a; 3531: 19a; 3592: 19a; 3789: 19a; 3997: 19a; 4137: 19a; 6205: 19a; 6913: 19a; 7965: 19a - Y.P. Chang 72: 8; 512: 3; 832: 3 - Y.T. Chang 4536: 6 - Y.T. Chang \& Z.S. Chang 3879: 8 - Z. Y. Chang 988: 8 - Charoenchai 104: 18 - Charoenphol et al. 4630: 8 - Chaudhri \& Siddiqui 534: 15 - Chaudkury 25241: 8 - L.Q. Chen 92221: 18 - S.C. Chen 13234: 18; 13751: 18 - W. Chen 83951: 19a - W.C. Chen 6496: 5 - Z.Z. Chen 53451: 19a - Cherian 65930: 15; 65971: 15 - Chermsirivathana 1039: 8 - [Poilane in] Chevalier 2375: 8 - Chevalier 29311: 8; 29329: 8; 30524: 13; 30976: 2; 39828: 13 - C.P. Chien 948: 5 - P. Chien 8309: 8 - Z.S. Chin 6148: 5 - China 4406: 18 - R.C. Ching 3694: 8; 4681: 8; 7426: 19a; 7493: 8; 9067: 8; 21571: 8; 24477: 8; 24727: 8 - Chitmaitree 3: 13 - Chong 527: 8; 621: 8 - Choudhury 82: 15 - K.L. Chu 1847: 19b; 2227: 8; 3066: 19b; 3067: 19b; 3820: 8; 3969: 8; 7914: 5 - Chuan Jing Xi (A) 1737: 5; 2829: 5; 5230: 5; 5572: 3 - S.H. Chun 1898: 19a; 2390: 19a - W.Y. Chun 8345: 8 - Cinatti 194: 13 - Clarke 8092: 15; 8667: 6; 9155: 8; 9507A: 8; 9507E: 8; 12317A: 6; 13499: 8; 13499B: 8; 13499D: 8; 13655: 8; 13655A: 8; 13655D: 8; 13690: 15; 13690D: 15; 13690F: 15; 13690H: 15; 15151A: 8; 15151C: 8; 15151D: 8; 15151E: 8; 16602A: 9; 16602B: 9; 16602C: 9; 16602F: 9; 16602G: 9; 16602H: 9; 16602J: 9; 16786: 15; 17836A: 8; 17836C: 8; 17836D: 8; 20511A: 15; 20511B: 15; 20511C: 15; 23811: 15; 23811A: 15; 23811B: 15; 23811D: 15; 25160B: 15; 25410: 8; 27339: 6; 27339A: 6; 27339B: 6; 27339C: 6; 27339D: 6; 27339F: 6; 27339G: 6; 27339H: 6; 34152: 15; 34152A: 15; 34152B: 15; 34152D: 15; 34152E: 15; 34152F: 15; 35945A: 8; 35946A: 8; 35946F: 8; 35946G: 8; 35946H: 8; 36004: 6; 36065A: 6; 36065B: 6; 36065C: 6; 36072: 6; 36087: 6; 36278A: 8; 36278B: 8; 37440: 8; 40222I: 18; 40822: 18; 40822A: 18; 40822C: 18; 40822D: 18; 40822G: 18; 40822H: 18; 40822K: 18; 40915: 8; 40952: 8; 40952A: 8; 41580: 8; 41776: 14; 41776A: 14; 41776B: 14; 41776C: 14; 41940: 8; 42514: 8; 42514A: 8; 42514C: 8; 42514D: 8; 42514E: 8; 45287: 8; 45800B: 8; 55287A: 8 - Clason 290: 8 - Clemens 9533: 13; 17235: 13; 18679: 13; 18827: 13 - Coert 246: 13 - Colani 3233: 18; 4024: 8 - Collett 114: 8; 131: 18; 135: 15; 971: 18 - Constable 4510: 11 - Cooke 83: 7 - Cooper 1137: 6; 1210: 6; 3630: 8; 3646: 15; 4919: 8; 4923: 6 - Cotter et al. N183: 6; N213: 6 - Craib 383: 8; 485: 15; 580: 15 - Cranfield 1842: 11 - Croat 63: 15 - Cuadra A266: 13 - Cuatrecasas \& Perez-Arbeláez 6451-A: 15 - Cunningham 86: 11; 520: 11 - Cunningham \& Milthorpe 2972: 11.

d'Alleizette 1504: 15 - D'Arcy 6438: 15 - Dai, TianLun 102265: 19b; 102475: 8; 103333: 8; 103348: 8; 103356: 8; 103365: 19b; 103493: 8; 103582: 8; 103684: 8; 103890: 8; 104321: 8; 107160: 8; 107272: 8; 107288: 8 - Đaö et al. 191: 8 - Davis 112: 11 - Day 10: 15 - Dayao Shan Exped. 11176: 8; 11722: 8; 810740: 8 - De Haas 2053: 6 - Deb 255: 8; 1447: 14 - Debao Exped. 3-47365: 19a - Degener 11815: 15 - Deighton 4502: 15 - Delavay 904: 8; 3302: 3; 3539: 19b; 4192: 8; 4279: 3; 4699: 8 - Demarz D3326: 12; D4037: 12 - Den, FanBin 5267: 8 — Deng, MengBing 4881: 8 - Dhevoj 162: 6; 245: 6 — Dickason 5140: 8; 6743: 10; 7706: 9 
- Dien 300: 13 - Diepenhorst 440: 13 - Dobremez 761: 6; 2646: 15 - Dorzi 68: 15 - Drummond 223: 12 - Drummond herb. 23834: 15 - Dryander 2377: 15 - Ducloux 264: 8; 476: 8; 484: $16 ; 533: 14 ; 805: 5 ; 843: 14 ; 1418: 3 ; 2221: 8 ; 2936: 8 ; 3022: 5 ; 3036: 19 b ; 3044: 4 ; 3094$ : 8; 3095: 8; 3630: 8; 3635: 8; 3637: 19b; 4913: 8; 5459: 5; 5556: 14; 6397: 3; 6820: 8; 7032: 3; 7362: 8 - Dudgeon \& Kenoyer 461: 8 - Duport 263: 15; 264: 13 - Duss 2: 15 - Duthie 1840: 8; 6674: 15 .

Eberhardt 3132: 18; 3357: 18 - Edgeworth 420: 8; 421: 15 - Eggers 1115: 15; 1135: 15 Ekman 7143: 15; 8344: 15 - Elbert 366: 13; 367: 13; 1531: 8 - Erlanson 5186: 13; 5495: 13 - Esquirol 50: 19a; 224: 8; 470: 19; 976: 19a; 2183: 19; 5013: 8 - Evrard 755: 13; 1627: 13; 1688: $13 ; 1864: 13 ; 2374: 2$.

Rev. E. Faber 76: 8; 635: 8; 1199: 5; 1770: 8 - C.S. Fan \& Y.Y. Li 554: 8 - M.Y. Fang 24777: 19b - W.P. Fang 4198: 19b; 5592: 8; 5605: 5; 12704: 19b; 12705: 19b; 15276: 19b; 15561: 8; 18032: 8; 52195: 8 - Fang, WenZhe 7962: 8 - Fang Ding 36898: 19b - Fang Ding \& J.F. Wei 3-1208: 8 - Fanshawe 3: 15 - Farges 106bis: 8; 871: 19b - K. M. Feng 2824: 5; 3058: 8; 7354 : 8; 7925: 8; 10844: 8; 11128: 4; 11424: 5; 12514: 8; 12804: 8; 14172: 14; 14485: 14; 24482: 8; 50364: 3; 50441: 8 - X.F. Feng 15730: 8 - Filson 8772: 12 - Fischer 3671: 7 - Fischer herb. 190: 8; 840: 15 - Flatt 141: 8 - Forbes 4104: 8 - Ford 290: 19a - Forde 1350: 11 - Forest Division Officer 23: 15; 24: 15 - Forest Herb. Ibadan 22455: 13 - Forrest 3015: 8; 7225: 8; 7540: 19b; 7854: 8; 11296: 8; 11567: 3; 12026: 19b; 12922: 5; 13591: 14; 15923: 19b; 17138: 10; 18091: 19b; 18206: 19b; 22149: 5; 24267: 19b; 25139: 8; 29501: 19b - Fosberg 13307: 15; 27156: 15 - Fosberg \& Nasir 56934: 15 - Franck 403: 13; 494: 13 - KunTsun Fu 5620: 8; 6045: 8; 12142: 8 - Fuchuan Exped. 7-337: 10 - Fujimura 100: 6.

Galathea Exped. 1225: 15 - Gale, U Mg 12903: 15 - Gale-2, U Mg 6056: 10; 12262: 15 - Gallatly 195: 8 - Gamble 245A: 15; 3414a: 8; 7330: 8; 7358: 15; 8872: 15; 9796: 6; 9878: 8; 15483: 7; 17141: 13 - Gammie 1232: 6 - C.Z. Gao et al. 73140: 18 - Gardner 820: 11; 2164 p.p.: 11; 2164 p.p.: 12; 12286: 11 - Gardner \& Blackall 552: 12 - Garrett 480: 8; 831: 8 - Gaumer 23806: 15 - A.S. George 1029: 11; 10185: 12; 11533: 12 - N. Gill 264: 8; 273: 15 - Gillis 8661: 15; 8664: 15 - Goodall 95: 11;3271: 11 - Grierson \& Long 2968: 8; 2989: 15 - Griffith 316: 15; 318: 8; 320: 8; 725: 15; 973: 9 - Griffith herb. 5874/1: 13; 5875: 6; 5876: 9; 5877: 15; 5877/1: 8 - Guangfu Exped. 1173: 8 - Guangxi Exped. 411: 18 - Guangxi Lunggang Exped. 10959: 18 - Guangxi Provinc. Museum 8596: 8; 9512: 8; 13910: 19a - Guha Bakshi 757: 15 - B.L. Gupta 17: 15; 26266: 15 - G.S. Gupta 915: 8.

Haines 342: 15; 588: 15; 716: 6; 2433: 15 - Hajra 489: 8 - Hallier C15a: 13; C15b: 13 - Hamilton 490: 15; 491: 13 - Hammond 964: 13 - Hancock 53: 5; 199: 8; 239: 8 - Handel-Mazzetti 751: 16; 4929: 3; 5363: 8; 5663: 16; 7041: 5; 10020: 8; 10813: 8; 10877: 19a; 12693: 8 - Hansen \& Smitinand 12024: 18 - K.S. Hao 428: 19b - Hara et al. 6303938: 15; 6303941: 8; 6303945: 8 - Harmand 954: 13; 964: 13 - Hart 20: 15; 412: 15; 450: 15 - Hartley (Eyles herbarium) 8540: 15 - Hautefeuille 128: 8; 134: 8 - X.T. He 3-14165: 18 - ZhiGang He \& Y.M. Zhang 632: 8 — Zhu He 12059: 8 - Zhu He et al. 11580: 8 - Heinig 105H: 18; 513: 18; 641: 18 - Henan Forestry Team 740: 8 - Hennipman 3161: 8 - Henry 357: 8; 2487: 8; 2595: 8; 2905: 8; 3062 : 8; 3220: 5; 4186: 5; 4357: 8; 4466: 8; 4467: 8; 7004: 8; 8347: 18; 8866: 5; 9229: 5; 9229a: 5; 9229b: 5; 9229c: 5; 9229d: 5; 9340: 4; 9340a: 4; 9340b: 4; 9340c: 4; 9489: 16; 9954: 8; 9954a: 8; 10715: 19b; 10715A: 19b; 10715B: 19b; 11892: 19b; 12622: 14; 12694: 14 - N.T. Hiep et al. NTH 3381: 8 - Hieronymy 9: 15; 181: 15 - C. Ho 11460: 5 - K.S. Ho 428: 19b - DiPing Ho 47213: 8 - Pham-Hoàng Hô 5240: 13 - Y. Ho 1173: 8 - Y.Y. Ho 23: 8; 856: 8; 1822: 8; 22193: 8; 24677: 8; 25617: 8; 26458: 8; 30353: 8; 30887: 8 - Hohenacker 1450: 8 - Hole 30875: 15 - JiaXiang Hong 762: 8; 1054: 8 - Hooker \& Thomson 746: 8 - T. Horsefield herb. 24: 8 - Ping Hou 60-019: 3 - Howard 14919: 15 - Howard \& Proctor 13521: 15 - Howard et al. 18946: 15 - Howell 120: 8 - C.H. Hsieh 40753: 5; 41660: 5 - C.H. Hsiung et al. 33123: 8 - ChiMing Hu 423: 8; 523: 8; 5540: 8 - S.X. Hu \& Y.K. Wu 12: 18 - S.Y. Hu 1085: 19b; 1130: 19b - W.K. Hu 8909: 19b; 8981: 8; 9077: 19b - W.K. Hu \& C. Ho 11506: 5 - YueYing Hu \& ShaoKan Wen 580659: 4 - C. Huang 43284: 19a - JiePing Huang 1820: 5 - M.Q. Huang 3-0848: 19a - SuHua Huang 327: 5; 346: 14 - Y. Huang 40898: 19a - ZhuQing Huang 253: 3 - Huanjiang Exped. 4-3-1951: 18 - Hügel 659: 15; 747: 8; 867: 15 - Hullett 355: 13 - Hunger \& Kilian 4044: 11 - Husain 100: 15. 
Imperial Forestry Inst. 23717: 15 - Iwatsuki \& Fukuoka T-3966: 8.

Jaag 1357: 8 - Jack 4309: 15; 6732: 15 - Jacobs 4907: 13 - Jacquemont 216: 15; 1289: 8; 1498: 15; 2459: 15 - Janaki 368: 15 - Jayaweera 673: 15 - GuangXing Jiang 3-0715: 19a - Jiangxi Team 1568: 8 - Jinxiu Exped. 1-319: 10 - J. Joseph 13508: 15; 48321: 15; 48506: 8 - Joshi et al. 75/3478: 15 - Junghuhn 50: 13; 54: 8; 189: 8 - plantae Junghuhnianae 537: 13.

Kanai 11991: 6; 670002: 15; 673338: 6 - Kanai \& Chuma 676126: 6 - Kanai et al. 6303937: 15 - Kanjilal 5928: 8; 6126: 8; 6224: 8 - Kanodia 1024: 15; 1289: 15 - Kapoor et al. 75569: 8 - Kaul 90: 15 - Kazmi 114: 15 - J. Keenan et al. 3122: 8 - KeKe team [S. Crawford, C. Grey-Wilson, D. Long, R. McBeath, H. Noltie, M. Sinnott, et al.] 974: 8; 1225: 8 - A.F.G. Kerr 2235: 8; 2415: 20; 2605: 18; 2764: 8; 3479: 13; 4783: 20; 6524: 8; 6527: 8; 6537: 14; 7985: 2; 7985a: 2; 9697: 18; 10223: 20; 20361 p.p.: 18; 20361 p.p.: 20 - F.H.W. Kerr 2141: 15 - Keshavanani 30: 15 - Khalil 32: 14 - A.Y. Khan 74: 15 - S. A. Khan 102: 15 - M.P. Khant 15209: 14 - Po Khant 1027: 15 - Khantchai 921: 20 - Khao \& Trung 2505: 8 - Khôi \& Đo 96: 8; 166: 8 - Kiah S.208: 13 - G. King 79: 15; 80: 8; 181: 6; 182: 6; 2023: 6 - King's collector 23: 18 - F. Kingdon-Ward 512: 8; 3707: 8; 3729: 15; 7700: 15; 7741 p.p.: 3; 7741 p.p.: 8; 8738: 15; 13267: 8; 14247: 8; 17009: 8; 17437: 9; 18097: 8; 18282: 8; 18312: 9; 18928: 14; 20276: 8; 20333: 15; 21360: 8; 22735: 8 - Kirat Ram 3667: 18 - S.-P. Ko 50857: 10; 51876: 10; 53139: 19a; 53400: 8; 53493: 10; 54768: 8; 55749: 18; 55903: 8; 55968: 8 - Koelz 3109: 8; 4273: 15; 25747: 4; 27343: 15 - Kollmann 691: 13 - Koorders 21329: 13; 22445: 13; 22990: 13; 27603: 13; 27604: 13; 27708: 8; 28705: 8; 29468: 8; 29475: 8; 38656: 13; 42502: 8; 43186: 8 - Kooy 734: 13; 884: 13; 1318: 13; 1337: 13 - Korthals 49: 13; 117: 8; 125: 8; 133: 8; 134: 8; 160: 13; 161: 13 - Kostermans 18384: 8; 19377: 8 - Koyama et al. T-49020: 20 - Kuntze 6413: 15; 6621: 8; 7141: 8 - Kurz 29: 15; 1082: 10; 1083: 20 - Kuswata 203: 13; 271: 13 - Kwangsi Exped. 7426: 19a - Kyi 511: 15; 12241: 15.

L.X.-V.N. 1009: 8 - Lacaita herb. 15449: 8 - Lace 2638: 15; 4463: 15; 5681'bis': 20 - Ladwa 38: 15 - LaHaye 49: 13 - ShuKun Lai \& MingChang Nie 6371: 10 - ShuSheng Lai 5010: 8 - Laibin Exped. 5-7-1-2: 18 - Lakela \& Almeda 30441: 15 - Lakshnahara 438: 13 - Lal Dhoj 84: 8 - YueYing Lan 4-4-110: 18 - Lancaster et al. 12359: 8 - Lane-Poole 356: 15 - Larsen 9305: 20 - Larsen et al. 1529: 17; 41887: 8; 44598: 8; 44613: 8 - S.K. Lau 373: 18; 2473: 8; 4730: 8; 24743: 8; 26862: 18; 27572: 18; 28682: 19a; 28853: 8; 29177: 8 - Y.W. Law 1152: 8; 1368: 8 - Lecomte \& Finet 455: 8; 1371: 13; 1465: 13 - Legendre 1616: 8 - Lehmann 209: 15 - Fr. Leon 361: 15 - Leschenault 263: 13 - BingGui Li \& ShaoBin Wan 5526: 8 - ChunChao Li 63234: 8 - Dou Li 59: 5 - HongJun Li 3290: 19b; 7826: 8; 8776: 8; 9449: 8; 9573: 8 - M.K. Li 13: 5; 280: 8; 749: 14; 925: 8; 1402: 8; 1452: 14; 1490: 8; 1536: 14; 1539: 14; 2241: 8; 5072: 8 - PeiYuan Li 4118: 19b; 5531: 19b - ShuGang Li 200410: 18 - T.C. Li 3108: 19b; 3171: 19b - T.G. Li 3640: 8 - XianQuan Li 228: 19b - XiWen Li 375: 14 - YanHui Li 631: 14; 3783: 14; 3784: 14; 3785: 14; 3834: 14 - YuanHui Li 1581: 18; 5646 : 8; 5822: 8; 5937: 5 - ZeTong Li 3165: 8 - ZeXian Li et al. 1421: 18 - ZhongTi Li 601668: 8 - ZhongTi Li \& YongChong Chen 600043: 8 - ZiXian Li 4: 19a - C.F. Liang 32840: 19; 34275: 8 - C.F. Liang \& D.L. Wu 32267: 19a - H.Y. Liang 62057: 18; 62216: 18 - H.Y. Liang \& R.K. Huang 31378: 10 - P.H. Liang 85997: 19a - Liangshan (Sichuan Econ. Plant Div.) 440: 19b - Liljestrand L-80: 5 - Limpricht 1628: 5 - Y. Ling 3-54266: 18 - Lingnan herb. 78012: 8 - Lingyun Exped. 3-6041: 8 - Tchen-ngo Liou 6016: 15; 10197: 8; 12349: 19b; 12398: $5 ; 12480: 5 ; 12482: 5 ; 14858: 19 b ; 16121: 19 b ; 19323: 8 ; 19327: 8 ; 19980: 8 ; 20626: 19 b$; 20847: 8; 22424: 8; 22725: 8 - Lister 355: 15; 358: 15 - FanDong Liu 2645: 8 - LingHan Liu 9941: 8 - LingHan Liu \& GuanZhou Ho 16601: 8 - QingXin Liu 51376: 8 - T.S. Liu 28: 10 - ZhenSu Liu 624: 5; 1577: 5; 1579: 8 - Longzhou Expedition 639: 18; 2-0198: 18; 2-0250: 18 - Lorence 2764: 15 - Lörzing 11978: 13; 17371: 15 - Lu Jiang Kao Cha Exped. 485: 19b - Ludlow \& Sheriff 1103: 15 - Ludlow et al. 6714: 8; 6735: 15; 7093: 15 - E. Lullfitz 2527: 12 - F. Lullfitz L2542: 11 - Luochang Exped. 4-1-1252: 19a; 4-1-1626: 19b; 4-1-1832: 18 - Luzhai Exped. 5-6-52: 18.

CongYi Ma 60-1416: 3 - MacGregor 887: 8; 1011: 13; 1019: 13; 1800: 1 - MaCrae 122: 15; 298: 13 - Madden 381: 15 - Maheshwari 5586: 15;88144: 15 - Maire 53: 3; 64: 3; 65: 3; 69: 3; 505: 3; 643: 19; 716: 8; 967: 8; 1046: 3; 1065: 19; 2054: 8; 2321: 8; 2712: 3; 2990: 3; 3267: 3; 6284: 
3; 6393: 16 - Maire in Bonati 3452: 16 - N.C. Majumdar \& R.N. Banerjee 406: 6 - Malla 4872: 6; 16028: 6 - Malla \& Kanai 674643: 8 - Malla \& Rajbhandari 374: 8 - Mambley 3418A: 15 - Manandhar 4607: 8; 10248A: 6 - Manandhar et al. 7440: 6 - Manuel 286: 15 - PinYi Mao 211: 3; 1197: 3; 1602: 3; 1738: 16; 1871: 5; 2006: 16; 4205: 8; 7183: 14; 7293: 8 - Marcan 1120: 2; 1560: 2 - Marnga 21732: 15 - Martin \& Bodinier 1858: 8 - Mason 17: 10; 24: 8 - Matthew \& Gastmans RHT-72747: 13; RHT-74366: 15 - Mawlie 3422A: 6 — Maxon \& Killip 1644: 15 - Maxwell 70-111: 13; 72-593: 18; 73-658: 18; 73-759: 2; 74-78: 20; 75-953: 17; 75-1081: 17; 76-391A: 18; 76-655: 18; 88-1202: 8; 89-91: 20; 89-1294: 8; 891610: 8; 91-133: 20; 95-1057: 8; 96-268: 20; 97-119: 20 - McLaren's collector 26F: 3; C134: 19b; 137: 8; 181: 5; 206F: 3; B289: 8; 298b: 8 - Medical Checking Office of Yu-chi Xian 2810: 5 - Meebold 761: 8; 3988: 15; 3989 (at CAL): 8; 3989 (at G): 15; 3990: 8; 6039: 8; 6163: 8; 6421: 14; 8545: 8; 10824: 8; 26429: 15 - Melville 16: 8 - Middleton et al. 2352: 17; 2616: 17 - Misra 47013: 15 - Mitchell N657A: 11 - Miyi Coll. Team 223: 8 - WanCun Mo 2756: 5; 2798: 5 - Modde 57: 15 - Modder 111: 15 - Moore 653: 18 - C.W.E. Moore 4869: 11; 5619: 11 - Motley 175: 13 - Mouret 279: 15 - S.M. Mu 180: 8; 21450: 8 - Mukerjee 86: 15; 1443: 15 - G. Murata \& Ch. Phengklai T-42308: 8 - Murata et al. T-15222: 8; 15980: 8; T-16022: 8 - Myint 29: 15.

N.G. Nair 3174: 18; 4827: 18 - Nakao 225: 8 - ZhiDi Nan 4747: 8; 5532: 18 - Nandan Exped. 4-5-233: 8 - Nanjing Bot. Garden Coll. 6274: 10 - Naurigal 97: 15 - Naw Mu Pa 17476: 8 - Nedi \& Idjan 355: 13 - New South Wales herb. (NSW) 181027: 11; 181028: 11; 181030: 12 — Newby 10603: 11 - Z.C. Ni et al. 1983: 6 - Nicolson 2356: 6; 2369: 8; 2688: 6 - Nishioka 397: 6 - Nông Van Tiep 2454: 18 - Nooteboom 667: 8 - North Guizhou Exped. 2483: 19a - Northwest Yunnan Team 63-6877: 5 - S. Noshiro et al. 9760174: 6.

Oil Plant \& Tree Investigation Team 65-0560: 3 - Oldfield herb. 288: 12 - Oswaston 537: 15.

Pai 1692: 7 - Panigrahi 2237: 15; 2440: $15 ; 2893: 15 ; 4072: 8$; 4671: 15; 4859: 15; 5751: 15; 10665 :

15; 11411: 15; 11746: 15; 12503: 15; 13790: 15; 20353: 8 - Panigrahi \& Misra BSI-6392: 15 - Pant 43322: 15; 43683: 15 - Parish 178: 10 - Parnell 98-34: 8 - Parry 393: 8; 1072: 15; 1113: 15 - Peele 1569: 8 - ShenJi Pei 59-9792: 18; 59-10376: 18 - Perrotet herb. 2083: 13 — Pételot 956: 18; 975: 18; 3168: 8; 3233: 18; 4024: 8; 6237: 8; 6910: 19a - Philippine Bureau Science (BS) 5339: 13; 7246: 13; 12952: 13; 43518: 13; 43546: 13 - Philippine Natl. Herb. (PNH) 6294: 15; 8156: 13; 8242: 15; 12182: 15; 22845: 15; 34072: 15; 36389: 15 - Pierre 6: 13; 11: 13; 1957: 13 - Pike 24: 11 - Pingguo Exped. 3-10166: 8 - Poilane 2080: 8; 2375: 8; 2420: 18?; 2766: 13; 3053: 17; 5332: 13; 5336: 17; 5472: 13; 5947: 2; 8417: 17; 8544: 13; 8768: 2; 8956: 13; 9047: 18; 9121: 2; 9797: 17; 11866: 18; 12420: 2; 12481: 13; 16180: 8; 17225: 8; 21650: 13; 26636: 8; 26707: 14; 26910: 14; 27098: 14; 28095: 18; 28379: 8; 29288: 18?; 35962: 8 - Polunin 1954: 6; 1986: 6 - Polunin et al. 5786: 15; 5897: 8 - Pooma 942: 10 - Popta 273: 13 - Powell 1160: 15 - D. Powell \& H.K. Chey 754: 13 - Pradham \& Shrestta 24: 6 - Prain's collector 8: 18; 83: 18; 85: 18; 90: 15; $95: 18$ - Pratt 423: 5 - Premanath 8312: 18 - Proctor 25735: 15 - Proshad sub Burkill 29479: 15 - Puri 8628: 7 - Put 332: 8; 473: 18; 2326: 17 ; 3166: 17 ; 4395: 8; 4498: 8 .

Qaiser 7009: 15 - BaSe Qian 1178: 8; 1506: 8 - ChongShu Qian 12704: 19b - Qiandongnan Team 3929: 8 - Qing-Zhan Team 6097: 6 - Qinghai-Xizang Expedition 13399: 5 - Bing-yun Qiu 50441: 8; 51376: 8; 52640: 8; 53220: 10; 55555: 8; 57813: 19b; 59279: 19b; 59627: 8; 60572 [in HBC]: 3; 60572 [in IBK, KUN]: 4 - Queen Sirikit Botanical Garden (QSBG) 5783: 8; 9740 : 8; 12247: 8; 12465: 8; 12815: 8; 17385: 20; 22150: 8 - Quentin 278: 15; 424: 15 - Questel 432: 15 - Qureshi 69: 15.

Rajbhandari \& Upadlyang 2207: 6 - K.R. Rajbhandari \& Roy 1455: 6; 2314: 6 - Ram 8809: 8; 8809a: 8 - Ran 8538: 8 - C.R. Rao 64: 15; 153: 15 - G.V.S. Rao 23122: 8 - M.S. Rao 15: 15 - R.S. Rao 10248: 8; 10249: 8; 10259: 15; 10641: 8; 10829: 8; 10847: 8 - T.S. Rao 10830: 15 - R.W. Read 1346: 15 - Reinwardtianum herb. 1313: 13 - Ribu \& Rhomoo 3218: 15; 3253: 8 - A.D. Ricksecker 89: 15 - J.J. Ricksecker 35: 15 - Riedlé 218: 13 - Ripley 127: 8 - Robinson 1423: 13 - Robson 97: 15 - Rock 337: 8; 453: 8; 1707: 8; 2486: 14; 5172: 5; 6592: 8; 7215: 8; 11515: 8 - Rodd 2826: 11 - Rodger 124: 14 - Roxburgh herb. 2442: 13 - Royce 6622: 11 . 
Sadakorn 247: 8 - Saijn \& Amatya 18/77: 6 - Saldanha 1973: 7; 10167: 13 - B. Sangkhachand 551: 18 - P. Sangkhachand 138: 8 - Santa 43: 15 - Santapau 2958: 7; 3105: 7; 3106: 7; 9545 : 7; 11563: 7; 11564: 7; 11565: 7; 11566: 7 - Santisuk 1449: 8 - Saroja 9689: 13 - Satheesorn 3561: 13 - Saulière 767: 6 - Schierbrand 7: 8; 116: 13 - Schilling 612: 6 - Schlagintweit 11859: 15; 13540: 15 - Schlichen 10055: 15 - Schmitz 2365: 13 - Schneider 2559: 8; 2575: 8 - Schoch 358: 8 - Sedgwick \& Bell 4564: 7 - Sen Gupta 304: 15 - Serm 44: 8 - Sete 332: 13 - G. Shaestra et al. 681: 8 - J.B. Shaestra 2718: 6 - Shakya \& Rajbhandari 3277: 15 - Sharma 90: 15 - T. Shen 70: 8; 818: 8 - B.V. Shetty 131: 15 - T. Shimizu et al. T-11686: 8; T-22555: 8 - Sichuan Univ. Biol. Dept. Exped. 6235: 8; 52195: 8; 52938: 8; 53269: 8 Sichuan-Guizhou Exped. 2093: 8 - Sichuan-Liangjang Team 5830: 3 - Siddiqu \& Nasir 7331: 15 - J.K. Sikdar 4040: 15? - Silvestri 1901: 8; 1902: 8 - G.S. Sin 1044: 4; 1210: 10 S.S. Sin 50760: 8 - Sinclair \& Long 5613: 8 - Singapore herb. 34835: 13 - A. Singh et al. 54167: 15 - H. Singh 111: 15 - S. Singh 77: 15 - U. Singh 18: 15 - 1980 Sino-American Exped. 1443: 8 - Sino-American Guizhou Botanical Expedition 984: 8; 1256: 8; 1888: 10?; 1905: 10?; 2473: 10? - Sino-Russian Exped. 613: 14; 869: 14; 4137: 19a; 5798: 14; A0174: 8; A0188: 14 - Sino-Russian Yunnan-Laos Exped. 3163: 18 - Sino-Viet. Exped. 5: 8 - Slane 392: 15 - Smith \& Rant 164: 8 - H. Smith 2340: 19b; 13563: 8 - L.S. Smith 6344: 11 - W.W. Smith 48: 6; 230: 8; 302: 8; 336: 6; 459: 6; 731: 6 - Smitinand 3081: 8; 3095: 8; 4214: 20 - Smitinand \& Anderson 7219: 14; 7230: 8 - Sørensen et al. 1317: 20; 6332: 8 - Souza Novelo 176: 15 - Speck 1501: 11 - Spire 724: 20 - Srisanga 272: 8; 1369: 20;2210: 8 - Srisanga et al. 225: 20 - J.G. Srivastava et al. 48498: 15; 48937: 15; 53990: 8 - J.S. Srivastava 86635: 15 - Stainton 1212: 8; 1392: 6; 1604: 6; 5178: 8; 5181: 6; 5897: 8; 6054: 8; 6635: 8; 6659: 15 - Stainton et al. 3970: 6; 4287: 6; 7505: 6; 7720: 6; 8441: 6; 8552: 6; 8853: 15; 8923: 8; 8963: 8; 9255: 8; 4349: 8 - Standley 55188: 15 - Staples 131: 8; 429: 13 - Staples \& Wongprasert 140: 18; 141: 18; 157: 18; 320: 18; 322: 18; 405: 13 - Staples et al. 425: 10; 427: 8 - Stearn 65: 15 - Stehlé 7: 15 - Stehlé \& Stehlé 77/86: 15 - Steiner 495: 15; 570: 15; 1167: 15 - Steward \& Cheo 949: 8 - Steward et al. 429: 8 - K. Stewart 6: 11 - R.R. Stewart 1117: 15; 1301: 15; 13292: 15; 14731: 15 - Strachey \& Winterbottom 1: 15; 2: 8; 241: 15 - Strait [sub Dickason] 7706: 9 - Strid 20160: 11 - Sudha 16: 15 - Suehiro 426: 8; 747: 6 - Sukoe 16: 8 - Suksathan 1360: 8 - Sulit 2054: 15; 3547: 15 - BiXing Sun 64119: 3; 64485: 8; 64814: 8 - H.F. Sun 1567: 13 - HongFan Sun 1897a: 13; 7216: 13; 7316: 13 - S.L. Sun 1023: 5; 1032: 5 - Sunthorn 1: 13 - M. Suzuki et al. 88-80868: 6; 88-81080: 6.

Tagawa et al. T2627: 8 - H.H. Tai 296: 8 - L.Y. Tai 626: 8; 1431: 8 - T.W. Tak \& W.K. Chow 3217: 10 - H.F. Tan 700799: 8 - PeiXiang Tan 60083: 10 - S.Z. Tan 4-3-313: 18 - ChangLin Tang 86: 5; 460: 5 - L. Tang 260: 19a; 6808: 19a - DeDing Tao 282: 8; 681: 8; 1221: 16; 1353 : 16; 1419: 14 - GuoDing Tao 7082: 18 - Teijsmann 441: 13 - Ten, Pater S. 15: 8; 173: 3; 226 : 3; 1980: 3 - H.K. Teng 62: 8 - S.W. Teng 1100: 8 - R. Thapa 7752: 8 - J.B. Thompson 614: 15 - T. Thomson 868: 15 - Thorel 84: 13; 584: 13; 2625: 2; 2690: 18 - Thothathri 1044: 15; 10396: 8 - Tian-E Exped. 4-6-321: 19b; 4-6-729: 8 - Tiandeng Exped. 2-38: 18; 4-6-060: 8 - Tibet-Chinese Medicine Exped. 1042: 6 - Tirvengadum et al. 3065: 8 - Toppin 2523-13: 15; 2641: 15; 4023: 15; 4291: 8 - Townsend 73/339: 15 - Trinidad herb. 18873: 15 - Trudgen \& Merton 372: 11 - HseTao Tsai 58-8196: 8; 58-8379: 8; 58-8518: 8; 52419: 8; 52420: 8; 54284: 8; 54344: 8; 54545: 14; 54670: 8; 54705: 8; 54795: 8; 54932: 8; 56130: 8; 56239: 8; 56513: 8; 56660: 8; 57514: 19b; 58500: 8; 58865: 8; 58882: 8; 58959: 8; 58968: 8; 59018: 8 - W.T. Tsang 20645: 10 - Tsiang 1242: 5 - H.L. Tsiang 11122: 8; 35173: 19b; 35190: 19b; 35482: 5 Y. Tsiang 4595: 8; 4733: 8; 5581: 8; 6093: 8; 6806: 8; 6879: 8; 9212: 8; 9266: 8; 9408: 8; 9465 : 8; 11984: 8; 12048: 8; 12660: 14 - K.K. Tsoong 2493: 8; D1170: 8 - PuChin Tsoong 740: 19b; 1429: 19a - PuChin Tsoong \& K.Z. Kuang 546: 16 - T.M. Tsui 585: 19a; 768: 8 - DaHua Tu 905: 8; 3254: 19b; 3898: 8; 4079: 8; 4545: 5- T. Tuyama et al. 80416: 18.

Umpad 5: 8 - Umpai 125: 8.

Van Beusekom \& Charoenphol 1960: 18 - Van Beusekom \& Phengklai 2631: 8 - Van Beusekom et al. 3791: 1; 4691: 20 - Van der Maesen 5007: 15 - Van Steenis 21919: 11 - Vanpruk 412: 20 - Vegetat. Exped. Guangxi 53451: 19 - Vegetat. Team Chengdu Biol. Institute 5262: 5; 8576: 5; 8864: 8; 12019: 3; 14288 p.p.: 3; 14288 p.p.: 5; 14935: 16 - Vidal 1165: 13; 3362: 13; 4877: 13 - Von Türckheim 2591: 15 - Voogd 714: 13; 1758: 8. 
Waitz 41: 8; 44: 8; 45: 8; 89: 8 - Wallich 192: 15 - Wallich distr. 1324: 6; 1324.1,A!: 6; 1324bis: 6; 1325 p.p.: 14; 1325 p.p.: 15; 1325A: 15; 1325E, part a: $15 ; 1325 \mathrm{~F}$, part 1: 15; 1325F, part 2: 15 ; 1325G: $15 ; 1325 \mathrm{H}: 15 ; 1325 \mathrm{~J}$, part b: 13; 1325.1: $15 ; 1325.2$ : 15; 1325.4: 15; 1325.8: 15; 1326: 8 ; 1327: 13; 1327.1: 13 - M.E. Walsh 303: 13; 319: 8 - M.S. Walsh 441: 13 - C. Wang 40898: 19a - C. Wang \& H. Y. Liang 31378: 8 - C.W. Wang 79931: 18; 80276: 8; 80617: 14; 80876: 8; 80952: 14; 81956: 8; 82975: 8; 83394: 8; 83527: 19a; 83716: 19b; 84338: 19b; 84810: 8 - C.W. Wang et al. 81756: 5; 83568: 5; 83624: 5; 84221: 5; 89324: 19b - F.T. Wang 947: 8; 21826: 5; 21862: 5; 22308: 19b; 22564: 8; 22608: 5 - JingWu Wang \& ZhiCheng Shi 378: 8 - MingJin Wang 3632: 8 - TsoPin Wang 8039: 19b; 9890: 5; 9905: 8; 10771: 5; 12010: 5 - Z.G. Wang 3-50917: 19a - ZhengPing Wang 1124: 8 - ZuoBin Wang 1659: 8 - ZuoPin Wang 9717: 5 - Watt 6657: 8; 6816: 8 - J.F. Wei \& Ding Fang 3-5987: 19a - T.H. Wei 3-0954: 19a - ZhanYe Wei 115: 19 - ZiPin Wei 3035: 8; 3152: 19b - Wen-Shan Team 60-257: 5; 65-011: 4; 65-50: 5 - Wenger 356: 14 - West China Acad. Sci. Exped. 3067: 19b; 3254: 19b - Whaite \& Whaite 4201 p.p.: 11; 4201 p.p.: 12 - White 123: 13; 352: 15 - Wight 2001: 8 - Wight herb. 2000: 13; 2001: 7 - E.H. Wilson 1578: 19b; 2453: 5; 2631: 8; 3220: 5; 3221: 19b; 4185: 8; 4186a: 5; 4187: 19; 4188: 19; 4625: 19b; 5075: 8 - K.A. Wilson 2657: 12 - P.G. Wilson 8965: 11 — Winit 406: 17; 537: 13; 1526: 8; 1861: 20 - Wissmann 669: 16; 828: 8; 1042: 16; 1075: 16 — Witt 12412: 15 - Wood 89: 15 - Wraber 146: 6 - ChuanAn Wu 62-222: 8; 9775: 4; 9918: 8 - ChuanAn Wu et al. 9523: 8 - RaoZhong Wu 3140: 5 - ShuKung Wu 61-3773: 5; 61-3781: 5; 219: 8; 252: 14; 289: 19b; 408: 8; 692: 14; 2563: 5; 3605: 8; 3615: 5; 9001: 4.

JiaGen Xiao A003: 19b - JiHua Xiong \& ZiLin Chou 93633: 8 - ZhiHua Xiong et al. 31572: 19b; 33123: 8 - R.T. Xu 3-0618: 19a - Z.T. Xu 3-466079: 18.

HuiMing Yan 147: 14 - GuangFei Yang 59089: 19b; 59607: 5 - YongKang Yang 32542: 14 - JianSuo Yao 60-0175: 19a - Y. Yao 11343: 8 - Yaozhai Exped. 4-5-646: 8 - Yeshoda 630: 13 - T.S. Ying 4342: 4; 4752: 8 - WenQing Ying 60-1076: 8; 1707: 16; 1884: 5; 10173: 8 - ShaoLin Yü \& H.F. Tan 700627: 8 - SiZen Yü 49779: 19b - T.T. Yü 241: 16; 898: 5; 1681: 8; 2535: 5; 4136: 16; 14179: 8; 14830: 8; 17771: 8; 18205: 14; 18215: 14; 18219: 8; 20419: 8; 23008: 8 - Yuncker 17396: 15 - Yunnan Bot. Inst. Exped. 6408: 8 - Yunnan Trop. Biol. Exped. 486: 19b; 889: 19b; 3191: 14 - Yunnan University Expedition 348: 14; A-41: 14.

WenMin Zang 363: 5 - ZenJü Zao et al. 114742: 5; 114746: 5 - Zeppelius 97: 13 - Zeyauddin 56: 15 - QingSen Zhao 8713: 5; 8714: 5; 116549: 5 - Zhejiang Bot. Exped. 29666: 8 - JiXin Zhong 10920: 19a; 82596: 19; 85191: 19; 808452: 19b - PuQin Zhong 56: 8; 740 p.p.: 19; 740 p.p.: 19b - ShuQuan Zhong A61940: 18; A62062: 18 - Zhongshan Exped. 7-1466: 8 - HongFu Zhou 26466: 19b - Jun Zhou 8: 8 - Xuan Zhou 59: 14 - HeQin Zhu 433: 8 - PeiZhi Zhu 10337: 18; 10527: 8 - TaiPing Zhu 59 p.p.: 8; 59 p.p.: 10; 435: 8 - A. Zimmermann 1915: 6; 2104: 8 - R. Zimmermann 53: 13; 54: 13 - Zippelius 91: 13 - Zollinger 2560: 8; 2790: 13; 3188: 8 - Zöllner 4238: 15.

\section{INDEX TO NAMES}

Accepted names are in roman type, new species and combinations in bold, and synonyms in italics. The number after each name is the number of the species in the text; excl. = excluded species.

Cardiochlamys Oliv. discifera (C.K. Schneid.) C.Y. Wu 14 sinensis Hand.-Mazz. 16 thorelii Gagnep. 2

Cordisepalum Verdc. [p. 422] phalanthopetalum Staples 1 thorelii (Gagnep.) Verdc. 2

Dinetopsis Roberty [p. 428] grandiflora (Wall.) Roberty 6
Dinetus Sweet [p. 428]

'Dinetopsis' species group [p. 431]

'Dinetus' species group [p. 431] decorus (W.W. Sm.) Staples 3 dinetoides (C.K. Schneid.) Staples 4 duclouxii (Gagnep. \& Courchet) Staples 5 grandiflorus (Wall.) Staples 6 malabaricus (C.B. Clarke) Staples 7 paniculatus (Roxb.) Sweet 15 
(Dinetus)

racemosus (Roxb.) Buch.-Ham. ex Sweet 8 rhombicarpus Staples 9

truncatus (Kurz) Staples 10

Dufourea? velutina M. Martens \& Galeotti excl.

Duperreya Gaudich. [p. 451]

commixta (Staples) Staples 11

sericea Gaudich. 12

Ipomoea \#26 F. B. Forbes \& Hemsl. 5

cuspidata D.Don 6

modesta F. Muell. 12

Metaporana densiflora (Hallier f.) N.E. Br. excl.

obtusa (Balf.f.) Staples excl.

parvifolia (K. Afzel.) Verdc. excl.

Neuropeltis acuminata (P. Beauv.) Benth. excl.

Paralepistemon shirensis (Oliv.) Lejoly \& Lisowski excl.

Porana Burm.f. [p. 455]

acuminata P. Beauv. excl.

bialata Kerr 17

brevisepala C.Y. Wu \& S.H. Huang 4

commixta Staples 11

confertifolia C.Y. Wu 19b

cordifolia Ledeb. 8

decora W.W. Sm. 3

delavayi Gagnep. \& Courchet 19b

densiflora Hallier f. excl.

dichotoma Buch.-Ham. ex D.Don 8

dinetoides C.K. Schneid. 4

var. mienningensis S.H. Huang 4

discifera C.K. Schneid. 14

duclouxii Gagnep. \& Courchet 5

var. lasia (C.K. Schneid.) Hand.-Mazz. 5

elegans Zoll. 8

esquirolii H. Lév. 19, 19a

gagnepainiana $\mathrm{H}$. Lév. 8

grandiflora Wall. 6

henryi Verdc. 16

henryi auct. 14

lobata C.Y. Wu 5

lutingensis Lingelsh. 5

macrocephala Hand.-Mazz. ex Erdtman 3

mairei Gagnep. 3

var. holosericea C.Y. Wu 3

malabarica C.B. Clarke 7

megalantha Merr. 18

megathyrsa $\mathrm{C}$.Y. Wu 4

microsepala Hand.-Mazz. 3

nutans (Sessé \& Moç. ex Choisy) O’Donell excl.
(Porana)

obtusa Balf.f. excl.

paniculata Roxb. 15

paniculata auct. 16

parvifolia K. Afzel. excl.

racemosa J. Jacq. 8

racemosa Roxb. 8

var. sericocarpa C.Y. Wu 10

var. tomentella C.Y. Wu 8

var. violacea $\mathrm{C}$.Y. Wu 8

racemosa auct. 7

sericea (Gaudich.) F. Muell. 12

sinensis Hemsl. 19, 19a

var. delavayi (Gagnep. \& Courchet) Rehder $19 \mathrm{~b}$

speciosa Benth. 20

spectabilis Kurz 20

var. megalantha (Merr.) F.C. How ex

H.S. Kiu 18

spectabilis auct. 18

stenoloba Kurz 6

subrotundifolia De Wild. excl.

sutepensis Kerr 18

tomentosa Lesch. ex Choisy 15

triserialis C.K. Schneid. 5

var. lasia C.K. Schneid. 5

truncata Kurz 10

truncata auct. 9

velutina (M. Martens \& Galeotti) Hallier f. excl.

volubilis Burm.f. 13

var. burmanniana Blume 13

var. microcarpa Engl. 13

Poranopsis Roberty [p. 459]

discifera (C.K. Schneid.) Staples 14

paniculata (Roxb.) Roberty 15

sinensis (Hand.-Mazz.) Staples 16

spectabilis (Kurz) Roberty 20

Schillingia Verdc. ex Airy Shaw [p. 428]

Tridynamia Gagnep. [p. 467]

bialata (Kerr) Staples 17

eberhardtii Gagnep. 18

megalantha (Merr.) Staples 18

sinensis (Hemsl.) Staples 19

var. delavayi (Gagnep. \& Courchet) Staples $19 b$

var. sinensis $19 \mathrm{a}$

spectabilis (Kurz) Parmar 20

Vatica cordata $\mathrm{Hu}$ 19, 19a 